Historic, Archive Document

Do not assume content reflects current scientific knowledge, policies, or practices. 



\section{Tenth Annual Catalogue}

ISSUED BY=

\section{ZIMMERMAN SEED CO. 623-625 Quincy Street, Topeka, Kansas}

\section{Vegetable Garden Seeds}

All our Garden Seeds are grown for us, under special contracts, by the most experienced growers in the world. We handle only the Best Quality.

\section{Flower Garden Seeds}

You will find them fresh, of strong germination. Our mixtures contain the finest varieties. For beautiful flowers, plant our seed-none better.

\section{Field and Farm Seeds}

We are in the heart of the great farming section; have unexcelled facilities for handling field seeds; have the most modern seed-cleaning machinery and hold the trade of the most progressive and substantial farmers.

\section{Roses, Plants and Shrubs}

Our assortment under this head will be found most complete. Strong stock and reasonable prices.

\section{Poultry and Bee Supplies}

All the best quality and standard goods. Not the cheapest, perhaps, but The Best.

\section{Read the Following Carefully}

HOW TO ORDER Be sure to sign your name, Post-office, County and State, and if possible, use one of our order sheets and envelopes. Cash must accompany all orders, and money should be sent by Post-office order, Bank draft, Express order or Registered letter; small amounts will be accepted in postage stamps, providing you cannot send anything else. Do not send money loose in a letter without registering. It is not safe and, if lost, we are not responsible for it. Silver coin should be sewed or pasted in cloth or pasteboard to prevent its breaking through the envelope.

FREE BY MAIL We pay the postage on all orders sent by mail, at the prices named in the catalog. This brings them to the door of our customers, without trouble or expense.

EXPRESS AND FREIGHT On articles ordered sent by Express or Freight, the transportation charges must be paid by the customer, on receipt of the goods; when ordering always say whether goods shall be sent by Express or Freight and give plain shipping directions. Seeds are carried by express companies at $20 \%$ less than merchandise. When seeds catalogued at postpaid prices are sent with an express or freight shipment, we deduct the postage, which will reduce the cost of packets $1 \mathrm{c} ;$ oz. 1c; 1/2 1b. 4c; 1b. $8 \mathrm{c}$; pts. $8 \mathrm{c}$; qts. $15 \mathrm{c}$.

TESTED SEEDS All our seed is thoroughly tested and nothing sent out which we do not believe to be of good quality.

OUR GUARANTEE We guarantee that all seeds and other goods sent out by us will be fresh and of good quality, and if, upon arrival, they are not satisfactory, they are to be returned to us at once. We cannot guarantee crops and will not be held responsible for them or for any liability except as stated in this paragraph. 


\section{PEASE READ THIS FIRST.}

TO SEED BUYERS EVERYWHERE:

A Personal Statement:-Ten years ago I started the Zimmerman Seed Company in one room of the house where I lived. The business has shown a steady growth until today I occupy two entire floors at 623-25 Quincy Street in the heart of the business district of the Capital City of Kansas

I believe I have the largest mail-order seed house selling direct to planters in the entire West. Every year I have had the pleasure of adding thousands and thousands of customers to my list. Last year was the best year of our history, and I hope to make a still better record this year.

This business has been built up on the square deal principle-a dollar's worth of tested and guaranteed seed for every dollar we receive. I have never dealt in high-sounding "novelties" of any description, believing that in the end RIGHT DEALINGS and seed of true merit will be appreciated. I believe I hold a greater per cent of customers from one year to another than any other seedman, and I believe my records prove it.

Since I started this business I have made many radical departures from the path taken by the seed trade generally, and this year sees another change.

I have decided to get away from the expensive catalogue, which benefits no one except the printer, and issue a plain, common-sense book, which I want you to read from cover to cover. Instead of devoting a large amount of space to old and well-known varieties, I have simply listed them with prices and you can find what you want in a moment's time. The DIFFERENCE in the cost of the catalogues I propose to give to YOU by paying the cost of the money order that you use in making remittance.

I have also eliminated the field seed from this book, and you will find them described and priced on a separate circular which we enclose herewith.

My one endeavor has been to make this a plain, honest book-free from flashy-colored pictures and exaggerated descriptions of impossible vegetables.

I ask your orders for 1912 on the promise of the BEST QUALITY of goods at the LOWEST POSSIBLE prices. I intend to give each order as nearly as possible my personal attention, and will see that you are perfectly satisfied. I also promise that each and every order, whether for five cents or five hundred dollars, will get the same prompt and careful attention.

I will appreciate your business, whether your orders are large or small, and I will be glad to give you any special information or answer any questions you may desire to ask me that in any way relate to the seed business. It will be a pleasure to me to be of help to you in any way.

Yours sincerely,

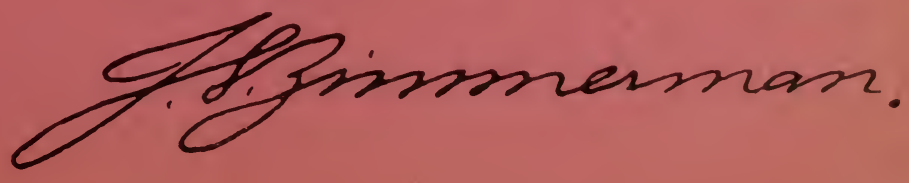




\section{ZIMMERMAN'S EARLY-BIRD COLLECTION}

\section{PACKETS FOR 25c, POSTPAID}

My early-bird collection, comprising as it does 7 of the earliest vegetables, has proven the best feature of my catalogue. I have made it a rule to change the varieties as new ones of special merit suggests an improvement. Each and every one of the varieties have been selected with the best of care as to earliness and quality. I am especially desirous that you try this collection this year. I will send $\tau$ packets to your address postpaid for only $25 \mathrm{c}$.

\section{ZIMMERMAN'S STRINGLESS WAX BEANS}

These are the best of all wax beans. Thie pods are round and absolutely stringless, very tender and of fine flavor. While the seed of this bean costs me more than any other, I have made the price low and as a special inducement have placed it in the Early-Bird Collection. Pkt. 5c; $1 / 2$ pt. $15 \mathrm{c}$; pt. 25c; qt. 40c; postpaid. By express or freight, 4 qts. $80 \mathrm{c}$; pk. $\$ 1.50$.

\section{EARLY JEWEL BEET}

I offered the earliest Jewel Beet for the first time last season and it more than came up to my expectation. The trouble with most early beets is their small size and pale color. This is entirely orercome in my "Early Jewel." While it comes with the very earliest, it is also of fine size, rich dark blood color and the flavor is all that could be desired, being crisp, tender and very sweet. Pkt. $10 \mathrm{c} ;$ oz. $15 \mathrm{c} ; 1 / 4 \mathrm{lb} .45 \mathrm{c} ; 1 / 2 \mathrm{lb}$. 60c; postpaid.

\section{EARLY MAMMOTH SWEET CORN}

This is the earliest extra large sweet corn on the market. Produces fine ears 8 to 10 inches long and ready for the market. - The earliest of the early offered by the majority of seedmen. I have lad this for a leader for a good many years and have found nothing to equal it in the early market. I know you will be pleased with it. Pkt. 5c; 1/2 pt. 15c; pt. 25c; qt. 45c; postpaid. By express or freight, pk. $\$ 1.50$.

\section{EARLY PERFECTION CUCUMBER}

The extreme earliness and great productiveness of this cucumber makes it one of the best varieties ever offered. The vines are of vigorous growth and produce their fine fruit in great abundance. They grow from 3 to 6 inches and are equally good for pickling or slicing. Pkt. 5c; oz. 12c; $1 / 4$ lb. 40c; $1 / 2$ lb. $70 \mathrm{c} ; 1 \mathrm{~b}$. $\$ 1.25$; postpaid.

\section{NEW EARLY CRISP LETTUCE}

I consider this one of the best varieties in this list, and offered it the first time last ycar. What other vegetable can fill the place of a good early lettuce, and this one is the Earliest of the Early; the most DELICIOUS OF DELICIOUS, and one of the best all-season varieties ever offered. Pkt. 5c; $1 / 4 \mathrm{lb} .50 \mathrm{c} ; 1 / 2 \mathrm{lb}$. $80 \mathrm{c} ; 1 \mathrm{lb}$. $\$ 1.50 ;$ postpaid.

\section{NEW EARLY GIANT RADISH}

I offered this radish for the first time last season. It is almost as early as the earliest and twice the size, but notwithstanding its large size it never gets strong or pithy. In fact. I believe it to be the best radish on the market. It is round turnip-slaped and grows from 6 to 8 inches in circumference. Skin a rich crimson, flesh pure white and never HOL. LOW OR PITHY. Pkt. 5c; oz. 10c; $1 / 4$ lb. 25c; 1/2 lb. 40e; 1 lb. $75 c$; postpaid.

\section{CRIMSON BALL TOMATO}

This is the first season I have offered this tomato in $m y$ catalogue. I secured the seed too late for the catalogue last season, and as $Y$ only liad a light stock. offered it on a special circular. If you were fortumate enough to have secured some of the seed last year you know what it is. If you did not. I want you to get it this year. It is a very light seeder, and grows perfectly round. smooth as an apple. a crimson color, and hence it was named Crimson Ball. Pkt. 10c; 1/2 0z. 20c; 1 oz. $40 \mathrm{c} ; 1 / 4$ lb. $\$ 1.40$; postpaid. 


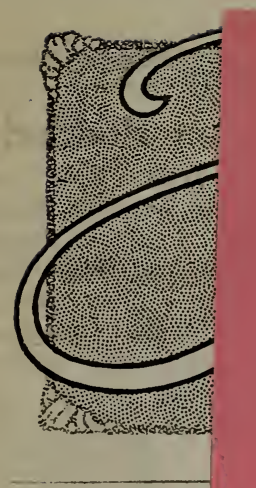

\section{I will allow you a Special Discount of 10 Per Cent}

If you will send me your order AT ONCE. It must be mailed to me on or before January 15, 1912. After that date this offer is cancelled.

Why not sit down right now and make out your order and save 10 per cent. J. S. Zimmerman.

inch in diam

Aspara

mail, postpaik. 250 for $\$ 1.60,500$ for $\$ 3.25,1,000$ for $\$ 6.00$. delayed.

We do not advise shipping Asparagus roots by freight, as they are liable to be

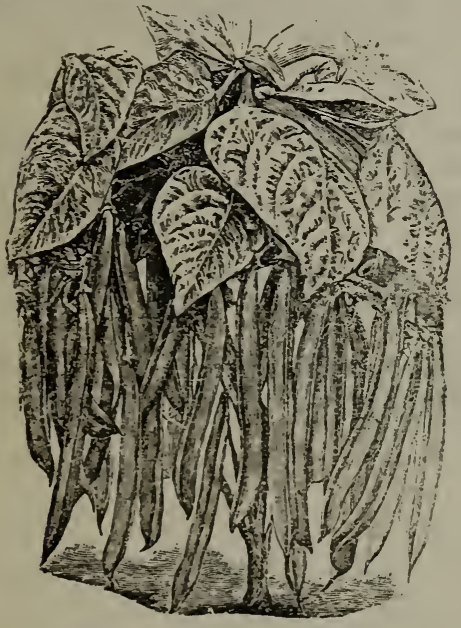

stringless Green Pod.

\section{Beans-Dwarf Green Pod}

Stringless Green Pod-The very best of the greenpod beans and ready for market about 2 weeks earlier than any other bean. Pods are rich green, round, medty, straight, tender and of fine flavor. It is the only absolutely stringless green-pod grown and is of the highest alue, not only to the market gardener but the home garden as well. Pkt. 5c; 1/2 pt. $15 \mathrm{c} ; \mathrm{pt}$. $25 \mathrm{c}$; qt. $40 \mathrm{c}$; postpaid. By express or freight, qt. $25 \mathrm{c}$; 4 qts. 90c; pk. $\$ 1.75$.

Imp. Early Red Valentine-A great favorite, extra early and very productive. Pkt. 5c; $1 / 4$ pt. $12 \mathrm{c} ; \mathrm{pt}$. 20c: 4t. 35c; postpaid. By express or freight, qt. 20c; 1 qts. $75 \mathrm{c} ;$ pk. $\$ 1.50$.

Hound Yellow Six Weeks-This is considered by many to be the earliest. Pkt. 5c; $1 / 2$ pt. 12c; pt. 20c; qt. $35 \mathrm{c}$; postpaid. By express or freight, 1 qt. $20 \mathrm{c}$; 4 qts, $75 \mathrm{c} ;$ pk. $\$ 1.50$.

White Marrowfat-Shells green or dry. Pkt. 5c; $1 / 2$ pt. $12 \mathrm{c}$; pt. $20 \mathrm{c}$; qt. $35 \mathrm{c}$; postpaid. By express or freight, qt. $20 \mathrm{c} ; 4$ qts. $75 \mathrm{c} ; \mathrm{pk}$. $\$ 1.50$.

White Kidney - The old favorite "Succotash" bean. Pkt. 5c; $1 / 2$ pt. $12 \mathrm{c}$; pt. 20c; qt. $35 \mathrm{c}$; postpald. By express or freight, qt. $20 \mathrm{c} ; 4$ qts. $75 \mathrm{c} ; \mathrm{pk}$. $\$ 1.50$.

Refugee or 1,000 to $1-O$ vigorous growth and the heaviest yielding green-podded bean. Pkt. 5c; $1 / 2$ pt. $12 \mathrm{c} ; 1$ pt. 20c; qt. 35c; postpaid. By express or freight, qt. $20 \mathrm{c} ; 4$ qts. $75 \mathrm{c} ; \mathrm{pk}$. $\$ 1.50$.

\section{Beans-Bush Limas}

Henderson's-The earliest Lima Bean, but of small size. Pkt. 5c; 1/2 pt. 15c; 1 pt. 25c; qt. $40 \mathrm{c}$; postpaid. By express or freight. qt. $25 \mathrm{c} ; 4$ qts. $80 \mathrm{c}$; pk. $\$ 1.50$.

Burpee's-The largest Lima Bean. Pods of large size, fine variety and will grow without poles or stakes. Pkt. $5 \mathrm{c}$; $1 / 2$ pt. $15 \mathrm{c}$; pt. $25 \mathrm{c} ;$ qt. $40 \mathrm{c}$; postpaid. By express or freight, qt. $25 \mathrm{c} ; 4$ qts. $90 \mathrm{c} ;$ pk. $\$ 1.75$.

Notice-Our beans are put up in dry measure pts. and qts. $1 / 2$ pt. per qt. more than the measures generally used.

Zimmerman Seed Company:

Winfield, Kan., March 23, 1911.

We are much pleased with the seeds we bought last year and are glad to send you another order this season. Wish you a successful year.-Mrs. Margaret Ross.

Zimmerman Seed Company:

Winfield, Kan., March 30, 1911.

Thought I would write and let you know I received my garden seed all right. Was well pleased with it.-J. F. Bowser. 


\section{BEANS-Dwarf Wax Podded}

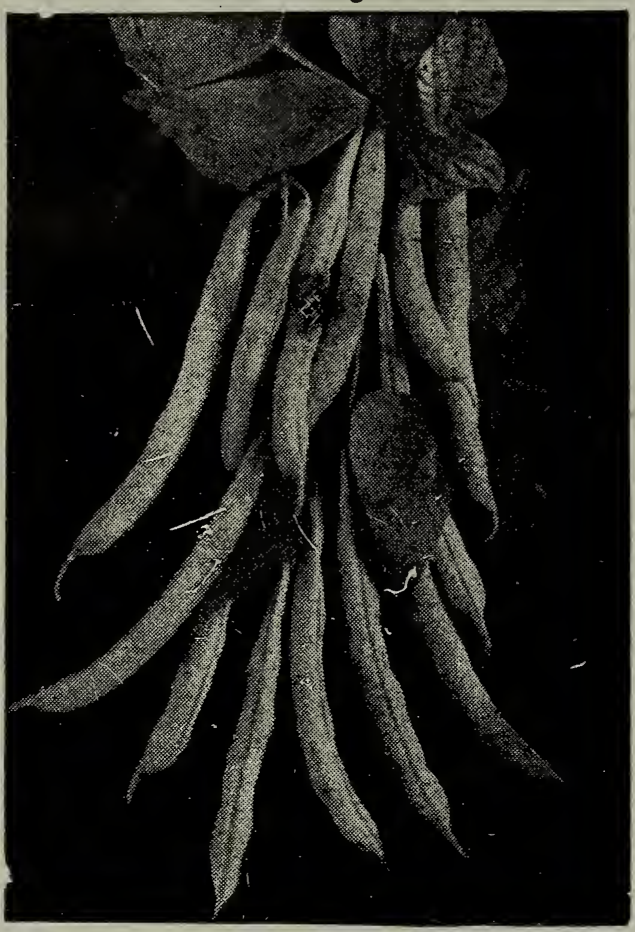

Zimmerman's Stringless Wax.

Zimmerman's Stringless Wax-This has proven to be one of the most popular beans we have ever offered, holds a place among wax beans similar to the Burpee Stringless Green-Pod among green beans. They are of the finest and richest flavor. The bean itself is a purplish color, shells green or dry, and is entirely different from any other bean. Do not fail to include this in your order. Pkt. $5 \mathrm{c} ; 1 / 2$ pt. $15 \mathrm{c}$; pt. $25 \mathrm{c}$; qt. $40 \mathrm{c}$; postpaid. By express or freight, qt. 25e; 4 qts. 90c; pk. $\$ 1.75$.

Zimmerman's German Wax-The very best strain of German Wax Bean, and is pronounced the earliest wax bean in cultivation and one of the very best, and cannot be excelled as a home or market bean. Pkt. 5c; 1/2 pt. 15c; pt. 25c; qt. 40c; postpaid. By express or freight, qt. $25 \mathrm{c} ; 4$ qts. $80 \mathrm{c} ;$ pk. $\$ 1.50$.

Dwarf Black Wax-This is the old favorite Pkt. 5c; $1 / 2$ pt. $15 \mathrm{c}$; pt. 25c; qt. 40c; postpaid. By express or freight, qt. $25 \mathrm{c} ; 4$ qts. $80 \mathrm{c} ; \mathrm{pk}$. $\$ 1.50$.

Wardwell's Kidney Wax-This is one of the best known wax beans and is a favorite everywhere. It is one of the earliest and most productive beans. Pkt. $5 \mathrm{c}$; $1 / 2$ pt. $15 \mathrm{c}$; pt. $25 \mathrm{c}$; qt. $40 \mathrm{c}$; postpaid. By express or freight, qt. $20 \mathrm{c} ; 4$ qts. $90 \mathrm{c}$; pk. $\$ 1.75$.

Improved Golden Wax-This is an old $\mathrm{fa}$ vorite variety, well known and does not need any description. Pk. 5c; $1 / 2$ pt. $15 \mathrm{c}$; pt. $25 \mathrm{c}$; qt. $40 \mathrm{c}$; postpaid. By express or freight, 4 qts. $90 \mathrm{c} ; \mathrm{pk}$. $\$ 1.75$.

Davis White Wax-Shells green or dry, and is a very productive and popular variety. Pkt. 5c; $1 / 2$ pt. 15c; pt. 25c; qt. 40c; postpaid. By express or freight, qt. 20c; 4 qts. 90c; pk. $\$ 1.75$.

Currie's Rust-Proof Golden Wax Bean-A decided improvement over the old Golden Wax. We have found it to be entirely rust-proof. Pkt. 5c;1/2 pt. $15 \mathrm{c} ; \mathrm{pt} .25 \mathrm{c} ;$ qt. $40 \mathrm{c}$; postpaid. By express or freight, qt. 25c; 4 qts. 80c; pk. $\$ 1.50$.

\section{Pole Beans}

Prices are as follows: Pkt. 5c; 1/2 pt. $15 \mathrm{c}$; pt. $25 \mathrm{c}$; qt. $40 \mathrm{c}$; postpaid. By express or freight, qt. $25 \mathrm{c} ; 4$ qts. $80 \mathrm{c}$; pk. $\$ 1.50$.

Kentucky Wonder-I consider this one of the best and most profitable beans grown. Pods measure 7 inches in length.

Lazy Wife-Pods 6 inches in length. As a shell bean for winter they have few equals and no superior.

Cutshort or Cornhill-The old well-known cornfield bean.

King of the Garden Lima-The largest and best pole lima bean grown.

Early Golden Cluster Wax-Fine pole wax bean, either string or shelled.

Notice-Our beans are put up in dry mea sure pts. and qts. about $1 / 8 \mathrm{pt}$. per qt. more than the measures generally used.

Zimmerman Seed Company:

Gypsum, Kan., April 5, 1911.

I am more than pleased with the seed. I have sown tomatoes and was surprised to see them come up. They came up quicker than any seed I have ever seen. Your seed cannot be beat.

Zimmerman Seed Company:

Grainfield, Kan., May 22, 1911

The seed I bourht of you row nleoly and you mey look for enother orter next year. I thank you for the many extra puokames int me.-Mra. W. A. Creinler. 


\section{Garden Beets}

Beet Seeds is a short crop, but you will find all our seed fresh and of strong germination.

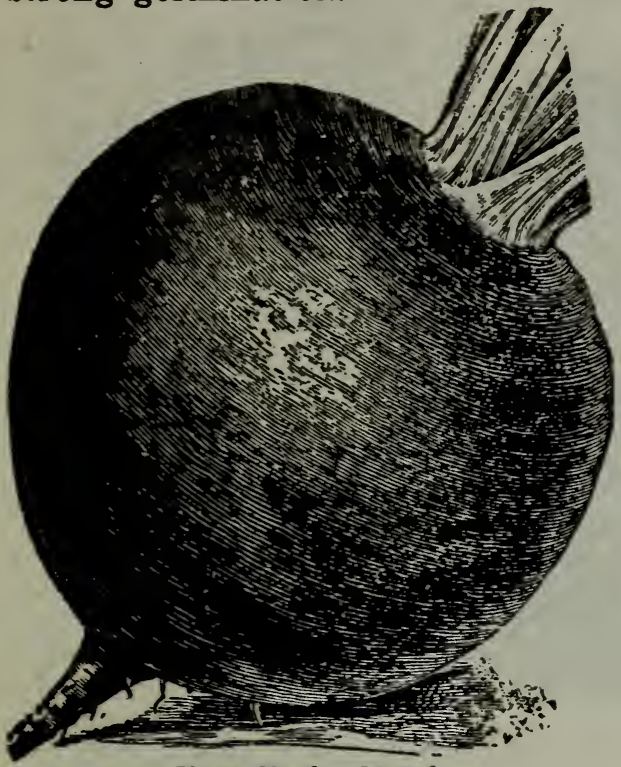

New Early Jewel

Early Jewel-This is a fine new beet offered by us the first time last season and has proven a winner. It is of fine size, rich dark blood color, and has a good flavor, crisp and sweet. Pkt. 5c; oz. 15c; $1 / 4$ lb. $45 \mathrm{c} ; 1 / 2$ lb. $80 \mathrm{c}$; lb. $\$ 1.60$; postpaid.

Zimmerman's Electric-Earliest of all beets and one of the best. If you have planted some varieties claimed to be the earliest, just sow some of my Electric alongside them and you will soon see that this is easily the earliest. Light red. sweet and free from tough fibre. Pkt. $5 c$; oz. $15 \mathrm{c} ; 1 / 4$ lb. $40 \mathrm{c} ; 1 / 2$ lb. $80 \mathrm{c} ; \mathrm{lb} . \$ 1.60$; postpaid.

Early Eclipse-Small tops of dark purplish green. Plkt. $5 \mathrm{c}$; oz. $10 \mathrm{c} ; 1 / 4$ lb. $30 \mathrm{c}$; $1 / 2$ lb. 65 c; lb. $\$ 1.25$; postpaid.

Extra Early Lentz-A good keeper, sweet and light red in color. Pkt. $5 \mathrm{c}$; oz. $10 \mathrm{c} ; 1 / 4 \mathrm{lb} .40 \mathrm{c} ; 1 / 2 \mathrm{lb} .70 \mathrm{c} ; 1 \mathrm{lb} . \$ 1.40$; postpaid.

Crosby's Egyptian-Deep red, about black. Pkt. 5c; oz. 15c; 1/4 lb. 40c; $1 / 2$ lb. $80 \mathrm{c}$; lb. $\$ 1.60$; postpaid.

Extra Early Egyptian-The old popular variety and still claimed by many to be the earliest. Pkt. $5 \mathrm{c}$; oz. $10 \mathrm{c} ; 1 / 4$ lb. $30 \mathrm{c} ; 1 / 2$ lb. $65 \mathrm{c} ; \mathrm{lb} . \$ 1.25$; postpaid.

Edmand's Blood Turnip-Has short top; is round and smooth, dark blood red, very sweet and of large size. Pkt. $5 \mathrm{c} ; 0 z .10 \mathrm{c} ; 1 / 4 \mathrm{lb} .35 \mathrm{c} ; 1 / 2 \mathrm{lb} .65 \mathrm{c} ; \mathrm{lb}$. $\$ 1.25$; postpaid.

Half Long Blood-A standard summer variety, sweet and tender. Pkt. 5 c; oz. 10 c; $1 / 4$ lb. 35 c; $1 / 2$ lb. 65 c; lb. $\$ 1.25$; postpaid.

Market Gardener's Beet-Undoubtedly one of the best ever introduced. Very symmetrical, with small tap root, attaining a large size. Deep blood red and fine grain. Pkt. $5 \mathrm{c}$; oz. $10 \mathrm{c} ; 1 / 4$ lb. $40 \mathrm{c} ; 1 / 2 \mathrm{lb} .75 \mathrm{c} ; \mathrm{lb} . \$ 1.40$; postpaid.

Swiss Chard-Most delicious for greens. Pkt. 5c; oz. 10c; 1/4 lb. 35c; 1/2 lb. 70 c; lb. $\$ 1.40$; postpaid.

\section{Mangel Wurzle and Sugar Beet}

The Mangel Wurzle crop this year is almost an entire failure, prices of new seed being very high. Prices are as follows: $1 \mathrm{oz} .5 \mathrm{c} ; 1 / 4 \mathrm{lb} .20 \mathrm{c} ; 1 / 2 \mathrm{lb}$. $35 \mathrm{c}$; lb. 70c; postpaid. By express or freight, 5 lbs. and over at $50 \mathrm{c}$ per $\mathrm{lb}$. We have the Golden Tankard, Long Red, Large Red Globe, Improved Wanzleben Sugar and Lane's Imperial Sugar.

I falled to recelve your catalogue and ordered from another house this year, but you will recelve my order next spring, as your seed are the best I ever tisef.-L. A. Jenkiks. 


\section{CABBAGE}

My cabbage seed is the best quality and strictly Long Island grown, which is acknowledged to be the best.

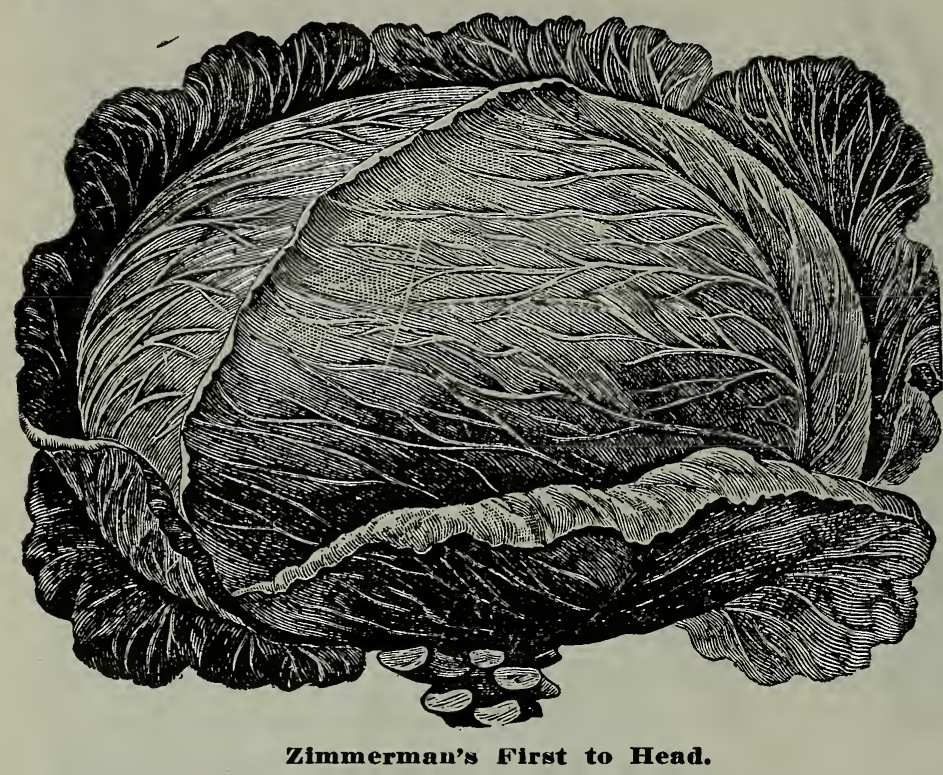

Zimmerman's First to Head produces fine solid heads in 70 to 80 days. The deep flat heads are uniform in shape and size. It is a beautiful cabbage in appearance and on account of its rapid growth far excels all others for tenderness. We are particularly anxious to have all our customers who raise cab. bage grow it this year. Pkt. 10c; 3 pkts. 20c; oz. 30 c; $1 / 4$ lb. $\$ 1.00$; postpaid.

Zimmerman's Earliest -This is the very earliest and reliable in every way. Almost every plant grows a fine solid head in a remarkably short space of time. Market gardeners will find this very profitable for extra early market. Heads are cone-shaped. Pkt. 5c; oz. 20c; 1/4 lb. 35c; 11 . $\$ 1.90$; postpaid.

St. Louis Market Cabbage-The seed I offer comes direct frnm the original introducer of St. Lnuis and is the TRUE ST. LOUIS MARKET SEED. Pkt. 5c; oz. 25c; 1/4 lb. 75; $1 / 2$ lb. $\$ 1.25$; lb. $\$ 2.25$; postpaid.

Early Winningstadt forms large cone-shaped heads of fine quality. Pkt. 5c; oz. 15c; $1 / 4$ lb. $45 c$; $1 / 2$ lb. 80c; lb. $\$ 1.50$; postpaid.

Early Jersey Wakefield-An extra large variety, too well known to need any description. Pkt. 5c; oz. 20c; $1 / 4$ lb. 60c; lb. $\$ 2.00$; postpaid.

Extra Early Express-One of the earliest on the market. Pkt. 5c; oz. 20c; 1/4 lb. 60c; lb. $\$ 2.00$; postpaid.

Zimmerman's Surehead-All head and always sure to head. The largest main crop variety of the Flat Dutch type. Pkt. 5c; oz. 20c; $1 / 4$ lb. 60c; lb. $\$ 2.00$; postpaid.

Giant Flat Dutch-An extra large late winter variety. which has no superior and is one of the old standards. Pkt. $5 \mathrm{c}$; oz. $20 \mathrm{c} ; 1 / 4 \mathrm{lb} .60 \mathrm{c} ; \mathrm{lb} . \$ 2.00$; postpaid.

Early Flat Dutch-The same type as the Ciant, but much earlier and not quite so large. Pkt. 5c; oz. 20c; $1 / 4$ lb. 60c; lb. $\$ 2.00$; postpaid.

Short-Stem Drumhead-Heads are of immense size, hard and solid, very uniform. Pkt. 5c; oz. $20 \mathrm{c}$; $1 / 4$ lb. $60 \mathrm{c}$; lb. $\$ 2.00$; postpaid.

Early Summer-One of the best and largest early varieties. Pkt. 5c; oz. 20c; 1/4 lb. 60 c; 11 . $\$ 2.00$; postpaid.

Extra Early Etampes-One of the earliest cabbages and of conical shape. Pkt. 5c; oz. 20c; $1 / 4$ lb. 60c; lb. $\$ 2.00$; postpaid.

Drumhead Savoy-Leaves are crimped and wrinkled in a peculiar manner. Heads are large and solid. Pkt. 5r; oz. 20c; $1 / 4$ lb. 55c; lb. $\$ 1.90$; postpaid.

Improved Danish Ball-Head-The famous variety from Denmark. Not so large as Late Flat Dutch, but the best keeper in the world. Pkt. 5e; oz. 20c; 1/4 lb. 60c; lb. $\$ 2$ : postpaid.

Mammoth Red Rock-The largest and surest heading red cabbage grown. Pkt. 5c; oz. $20 \mathrm{c} ; 1 / 4 \mathrm{lb}$. $60 \mathrm{c} ; \mathrm{lb}$. $\$ 2.00$; postpaid.

Use SILUG SHOT for Cabbage Worms. Lb. 20c; 3 lbs. 50c; postpaid. By express or freight at 5c per pound. 
Pavliftower. Our Caulflower seed is guaranteed to be LONE ISLAND grown.

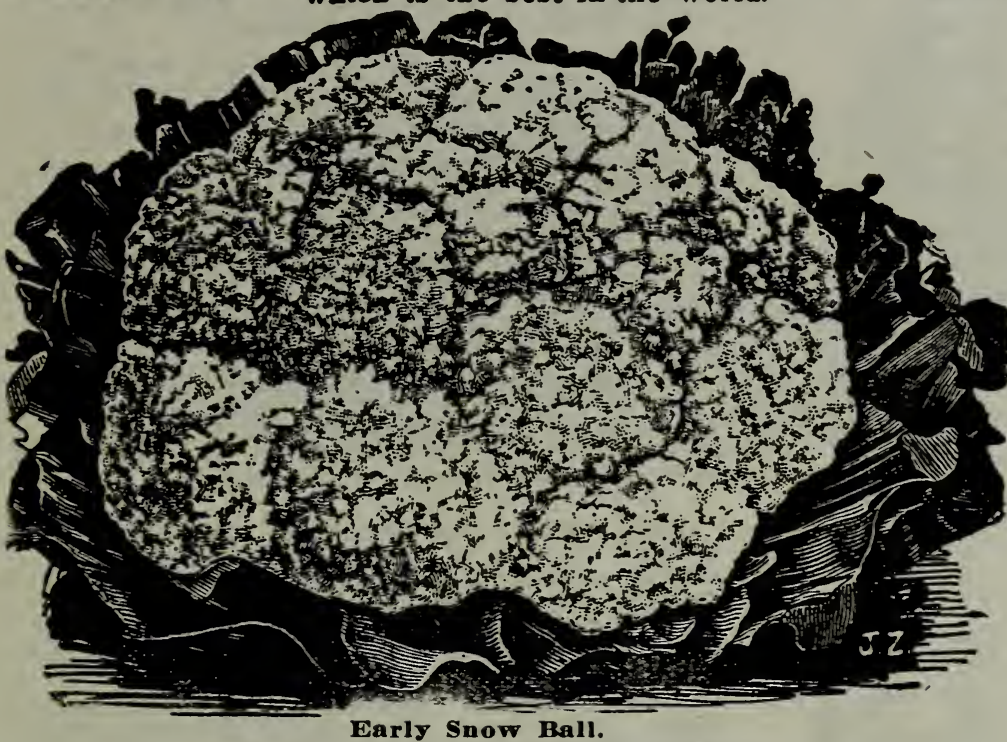

Carrots
Early Snowball-I offer my customers a superior strain of this best variety. In fact, it is impossible to obtain a better quality than my Early Snowball. Whether you grow Cauliflower for family or for market, you will find my Early Snowball what you want. Pkt. 15c; 2 pkts. 25c; $1 / 4$ oz. $70 \mathrm{c} ; 1 / 2$ oz. $\$ 1.30$; oz. $\$ 2.50$; postpald.

Early Dwarf Erfurt-A nother remarkable variety for heading and a favorite with many. Price, Pkt. 15c; pkts. 25c; 1/4 oz. $70 \mathrm{c}$; $1 / 2$ oz. $\$ 1.30 ;$ oz. $\$ 2.50$; postpald.

Early Paris ForeIng-Good for either forcing or out-ofdoor culture. Pkt. 5c: $1 / 4$ oz $25 c ; 1 / 2$ oz $45 \mathrm{c}$; oz. $90 \mathrm{c}$; postpaid.

Carrot seed is exceedingly short this year. Look out for old seed of poor germination. I guarantee my stock to be new 1911 grown.

ox-Heart or Guerrande-A fine Carrot and one of the very best for table use. Is a deep red color, sweet, tender and easy to pull. Pkt. 5c; oz. 15c; $1 / 41 \mathrm{~b} .45 \mathrm{c} ; 1 / 21 \mathrm{~b} .80 \mathrm{c} ; 1 \mathrm{~b}$. 81.50; postpaid.

Chantenay-The best bunching variety and extra early. Pkt. 5c; oz. 15c; 1/4 1b. 45e; 1/2 1b. $80 \mathrm{c} ; 1 \mathrm{~b}$. $\$ 1.50$; postpald.

Danvers Half Long-Broad shouldered, stump rooted, cylindrical in shape and very productive. Good for market, stock feeding and table use. Pkt. 5c; 0z. 15c; 1/4 1b. 45c; \% $1 \mathrm{~b} .80 \mathrm{c} ; 1 \mathrm{~b}$. $\$ 1.50$; postpald.

Improved Long Orange-The best of Orange variety and an old favorite; a good table variety and also fine for stock. Pkt. 5c; oz. 10c; $1 / 4$ lb. 35c; lb. $\$ 1.25$; postpaid.

Large White Belglan-Extra fine for stock, grows $1-3$ out of the ground and easily pulled. Pkt. 5c; oz. 10c; 1//4 1b. 25c; 1/2 1b. 40c; 1b. $75 \mathrm{c}$; postpald.

Large Yellow Belgian-Same as the White Belgian except in color, which is yellow. Pkt. 5c: oz. 10c: $1 / 4$ 1b. $25 \mathrm{c} ; 1 / 2$ 1b. $40 \mathrm{c} ; 1 \mathrm{~b}$. $75 \mathrm{c}$; postpaid.

\section{Celery}

Celery seed is very slow to germinate and care should be taken that the seed be fine and of good quality.

New Golden Self-Blanching-This is without doubt the best Celery. The stalks are crisp and solid and of delicious flavor. We offer the French seed of this variety as far superior to the ordinary strain generally sold. Pkt. 5c; 1/2 oz. 20c; oz. $35 \mathrm{c}$; $1 / 4$ 1b. $\$ 1.00$; 1b. $\$ 3.50$; postpaid.

New Pink Plume-A splendid new variety recently introduced; similar to White Plume except color, which is slightly red. Pkt. 5c: $1 / 2$ oz. $12 \mathrm{c} ;$ oz. $20 \mathrm{c} ; 1 / 4$ lb. $55 \mathrm{c} ; 1$ b. $\$ 1.90$ postpaid.

White Plume-An old standard variety and is still the leading sort Pkt. 5c; oz. 15c; $1 / 4$ lb. 50c; $1 / 2$ lb. $85 \mathrm{c}$; 1b. $\$ 1.50$; postpaid.

Glant Pascul-Stalks are exceedingly large, crisp and brittle. Is recommended for the South and West. Pkt. 5c; oz. 15c; 1/4 lb. 50c; 1/2 1b. 85c; 1b. \$1.50; postpaid.

Large Rlbbed Red-This is a sport of the Giant Pascal, but is thicker and stiffer. Pkt. $5 \mathrm{c}$; oz. $15 \mathrm{c}$; \% 1b. 50c; $1 / 2$ 1b. $85 \mathrm{c}$; 1b. $\$ 1.50$; postpaid.

Celeriac or Turnip-Rooted Celery -Grown for the roots alone. Pkt. 5e: -2. 15e: K 1b. 50c; postpaid.

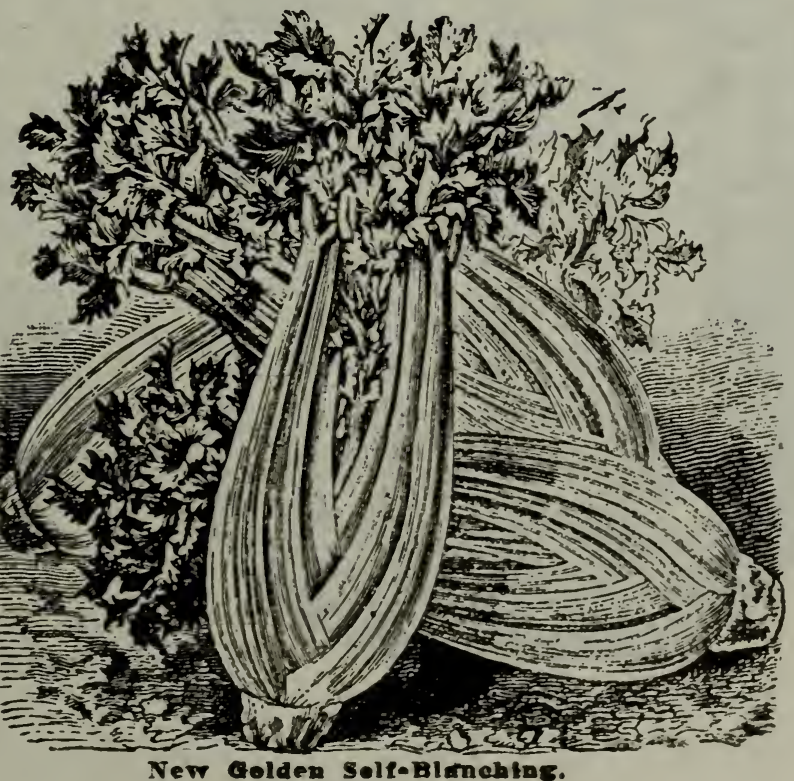

New Golden Self-Elamchine. 


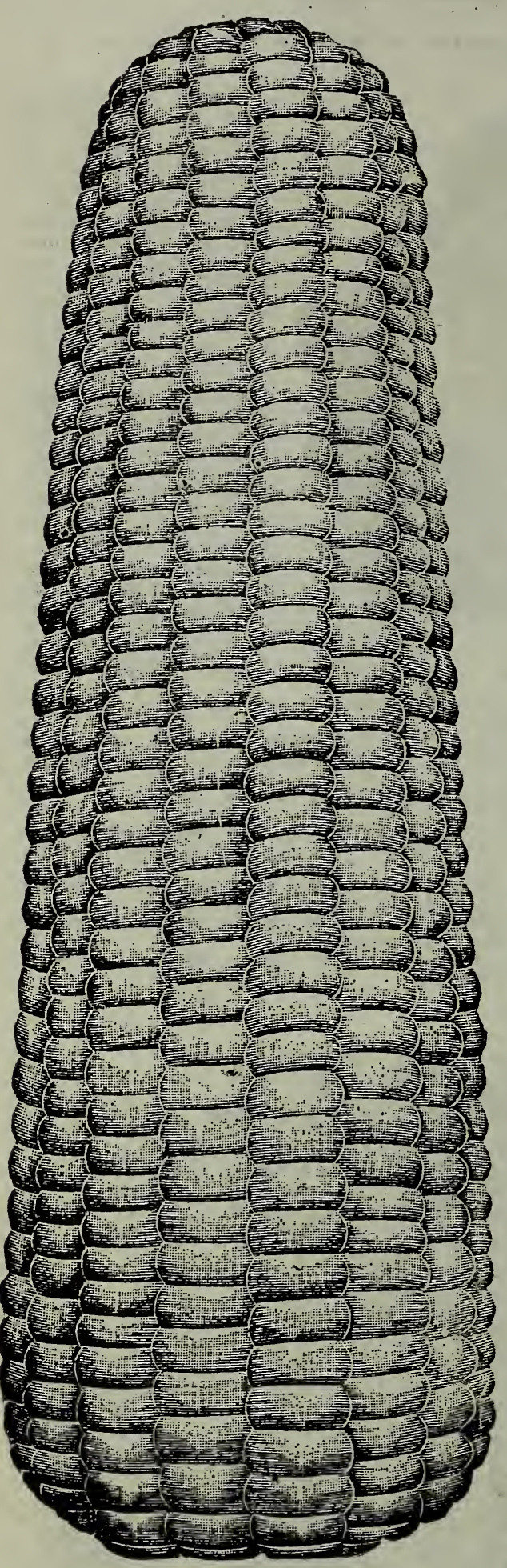

Zimmerman's Sugar Drijp.

\section{Sweet Corn}

My sweet Corn is of superior quality, carefully sorted, tested and graded.

Flease remember my Sweet Corn is put up in dry measure pts. and qts. $1 / 2 \mathrm{pt}$. per qt. more than measures generally used. Bear this in mind when making up your order.

New Sugar Drip-This undoubtedly is the sweetest and most delicious corn it is possible to secure. Very early, a heavy yiolder and unsurpassed for market trade It is early, ears large and filled with the sweetest and most delicious corn you have ever tasted. Pkt. 10c; 1/2 pt. 15c; pt. 25c; qt. 40c; postpaid. By express or freight, 4 qts. $80 \mathrm{c}$; pk. $\$ 1.50$.

Zimmerman's Early Mammoth-The largEst eared Early Sweet Corn ever produced. See description in my Early-Bird Collection. Prices, pkt. $10 \mathrm{c} ; 1 / 2$ pt. $15 \mathrm{e}$; pt. $25 \mathrm{c}$; q $140 \mathrm{c}$ postpaid. By express or freight, 4 qts, $80 \mathrm{c}$; pk. $\$ 1.50$.

Peep O'Day-The earliest of all. This is a variety that is of the greatest value to all who desire the Very Earliest variety and one that can be depended upon to yield a profitable crop. Pkt. 5c; $1 / 2$ pt. $12 \mathrm{c} ; \mathrm{pt}$. $20 \mathrm{c} ; \mathrm{qt}$. 35c; postpaid. By express or freight, 4 qts. $75 \mathrm{c} ;$ pk. \$1.25.

Early Cory-A popular extra early variety. Pkt. 5c; $1 / 2$ pt. $10 \mathrm{c}$; pt. $15 \mathrm{c}$; qt. $30 \mathrm{c}$; postpaid. By express or freight, 4 qts. $60 \mathrm{c}$; pk. $\$ 1.10$.

Golden Bantam-It is an attractiv $\epsilon$ yellow color; very early and exceedingly: sweet Pkt. 5c; 1/2 pt. 12c; pt. 20c; qt. 35c; postpaid. By express or freight, 4 qts. $75 \mathrm{c}$; pk. $\$ 1.40$.

Early Adams-Exceedingly early. but is not a sweet corn. Pkt. $5 \mathrm{c}$; $1 / 2 \mathrm{pt}$. $10 \mathrm{c}$; $\mathrm{pt}$. $15 \mathrm{c}$; qt. 30c; postpaid. By express or freight, 4 qts. $55 \mathrm{c}$; pk. $\$ 1.00$.

Perry's Hybrid-This is a gardener's favorite. Pkt. 5c; 1/2 pt. 10c; pt. 15c; qt. 30c; postpaid. By express or freight, 4 qts. $60 \mathrm{c}$; pk. $\$ 1.10$.

Early Minnesota-One of the very earliest varieties. Pkt. 5c; $1 / 2$ pt. $10 \mathrm{c} ; \mathrm{pt}$. 15c; qt. $30 \mathrm{c}$; postpaid. By express or freight, 4 qts. $60 \mathrm{c} ;$ pk. $\$ 1.10$.

Crosby's Early-Anoth $\in$ - extra variety. Pkt. 5c; $1 / 2$ pt. 10c; pt. $15 \mathrm{c}$; qt. 30c; postpaid. By express or freight, 4 qts, $60 \mathrm{c} ; \mathrm{pk}$. $\$ 1.10$.

Country Gentleman-Has been called Quaker Sweet, Shoe Peg, etc. Is well known and needs no description. Pkt. 5c; $1 / 2 \mathrm{pt}$. 12c; pt. 20c; qt. 35c; postpaid. By express or freight, 4 qts. T0c; pk. \$1.25.

Black Mexiean-Kernals are a bluish purple.when young, becoming black when dry. Pkt. 5c; $1 / 2$ pt. 12c; pt. 20c; qt. 35c; postpaid. By express or freight, 4 qts. $70 \mathrm{c} ;$ pk. $\$ 1.25$.

Improved Stowell's Evergreen-This is the most popular sweet corn grown and we exercise great care to have our stock pure and true to name. It is grown for me under spe:cial contract, only the choicest ears being saved for seed, and you will find it vastly superior to that generally sold. Pkt. 5c; $1 / 2$ pt. $12 \mathrm{c}$; pt. $20 \mathrm{c}$; qt. $35 \mathrm{c}$; postpaid. By. express or freight, 4 qts. 65 c; pk. $\$ 1.10$.

\section{Popcorn}

Pkt. 5c; 1/2 1b. 10c; 1b. 20c; postpaid." By express or freight, 10 or 20 lbs. at $6 \mathrm{c}$ per $1 \mathrm{~b}$.; 25 lbs. or over at 5c per $1 \mathrm{~b}$. I offer White Rice, White Pearl: Golden Vale. Queen's Golien. 


\section{Cucumbers}

My stock of Cucumbers is of the finest quality; grown for me under special contract.

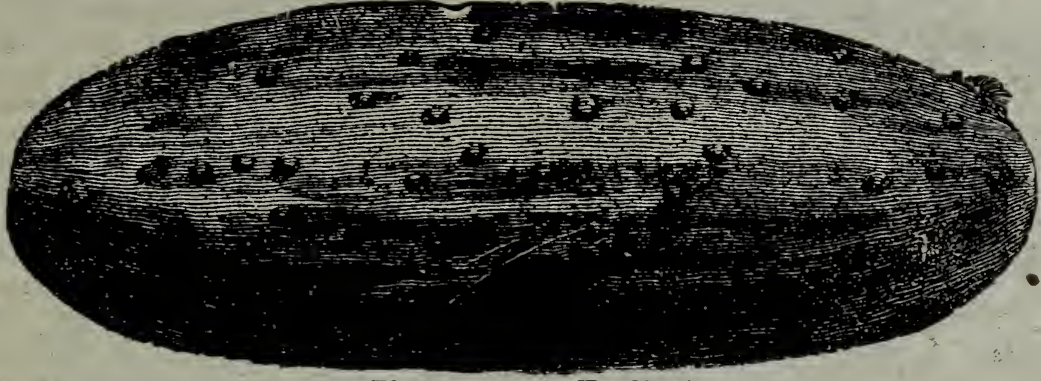

Zimmerman's Farliest.

Z i m m e r man's Earliest-The earliest Cucumber in the world. It is a heavy yielder, produces Cucumbers from 5 to 8 inches i. $\mathrm{l}$ e $\mathrm{ng} \mathrm{h}$ and from 1 to 3 inches in diameter. The fruit is handsome uniform in. size and of a dark green color. Not only good for table use but excel. lent for pickling. Pkt. 5c:oz. 10c: $1 / 4$ 1b. $35 \mathrm{c}: 1 / 2$ lb. $60 \mathrm{c}$ lb. $\$ 1: 20 ;-$ pestpaid. Irliugton White Spine-Fruit is of good size, straight and of perfect form. $5 \mathrm{c} ; 0 z .10 \mathrm{c} ; 1 / 4$ lb. $30 \mathrm{c} ; 1 \mathrm{~b} . \$ 1.00 ;$ postpaid.

Nicols Medium Green-An extra early pickling variety. Pkt. 5c-oz. $10 \mathrm{c}-1 / 4 \quad 1 \mathrm{~b} 30 \mathrm{c}$ 1b. $\$ 1.00$; postpaid.

Early White Splue-Vines vigorous, bearing early and abundantly. Flesh tender and of excellent flavor. Pkt. 5c; oz. $10 \mathrm{c} ; 1 / 4$ lb. $30 \mathrm{c} ; 1 \mathrm{~b}$. $\$ 1.00$; postpaid.

Chicago Plekling-Another fine pickling variety. Pkt 5c: oz. 10c: $1 / 41 \mathrm{~b} .30 \mathrm{c} ; \mathrm{b}$ $\$ 1.00 ;$. postpaid.

Boston lickling-One of the best and most productive cucumbers in the market. Pkt. 5c; oz. $10 \mathrm{c} ; 1 / 4$ lb. $30 \mathrm{c}$; lb. $\$ 1.00$; postpaid.

Early Russian-One of the rery earliest varieties. Pkt. 5c; $0 \% 10 \mathrm{c} ; 1 / 4 ; \mathrm{b} ; 30 \mathrm{c} ; 1 \mathrm{~b}$. $\$ 1.00$; postpaid.

Early Cluster-Produces its fruit in small clusers. Plet. 5e: 07. 10c; 1/4 Tb; $30 \mathrm{c}$ : $1 \mathrm{~b}$ $\$ 1.00$; postpaid.

New Everbearing-of small size; very early and productive. Fkt. 5c: $0 \% .10 \mathrm{c} ; 1 / 4$ lb 30c: lb. $\$ 1.00$; postpaid.

Japanese Climbing-Climbs on poles, trellises, etc. Cucumbers are good size and shape, shin dark green, turning to a brown when ripe. Pkt. 5c; oz. 15c; 1/4 1b. 40c; 1/2 lb. $70 \mathrm{c}$ : lb. $\$ 1.25$; postpaid.

West India Gherkin or Burr-Very small and used exclusively for pickling. A very distinct variety. Pkt. $5 \mathrm{c}$; oz. $20 \mathrm{c} ; 1 / 4 \mathrm{lb} .50 \mathrm{c} ; 1 / 21 \mathrm{~b} . \$ 1.10 ; 1 \mathrm{~b}$. $\$ 2.00$; postpaid.

Davis Perfect-A new variety of unusual merit. Grows 12 inches long, of symmetrical shape. Pkt. 5c; oz. 20c; $1 / 4$ lb. 50c; $1 / 2$ lb. $\$ 1.10 ; 1 b . \$ 2.00$; postpaid.

Improved Long Green-The most popular variety grown. Cucumbers grow from 12 to 20 inches in length. Pkt. 5c; oz. 10c; 1/4 lb. $30 \mathrm{c} ; 1 \mathrm{~b}$. $\$ 1.00$; postpaid.

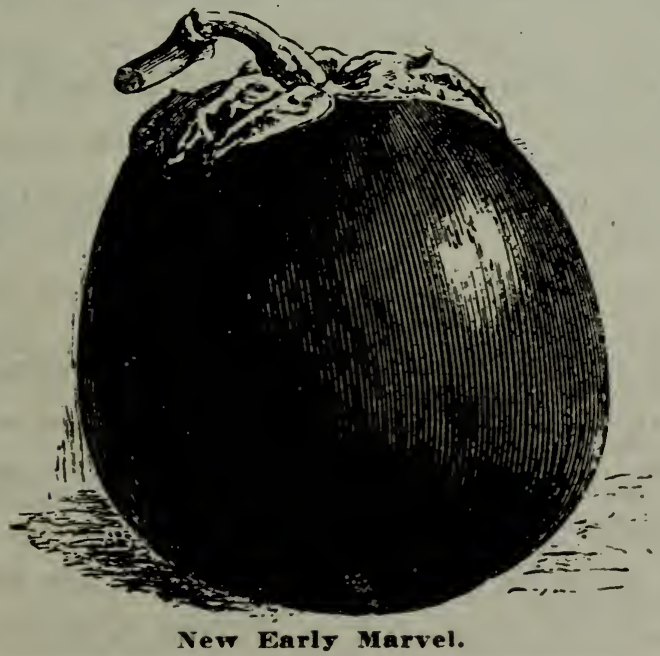

\section{Egg Plant}

Hlack Beauty-The Earliest Egg Plant and one of the best. The skin is a rich purplishblack. Pkt. $10 \mathrm{c} ; 1 / 2$ oz. $30 \mathrm{c} ; 0 \% .55 \mathrm{c} ; 1 / 4 \mathrm{lb}$. $\$ 1.50$; postpaid.

New York Improved Purple-The most popular variety. My seed is very select. Pkt. 5 c; $1 / 2$ oz. $25 \mathrm{c}$; oz. $40 \mathrm{c} ; 1 / 4$ lb. $\$ 1.25$; postpaid.

Clyde, Kan., June 29, 1911.

Zimmerman Seed Company:

Have always received such good garden seed and seed potatoes that I wish you handled table potatoes.-Volla Christian.

Washington, Kan., Feb. 8, 1911. Zimmerman Seed Company:

I will never buy seeds here again after trying yours, and have made you severa customers.-Mrs. F. J. Cook.

Zimmerman Seed Company:

Griffith, Colo., Feb. 7,1911

I $2 \mathrm{~m}$ so well pleased with your seeds I do not like to change. Your Peep-O-Day is truly wonderful, so early and sweet.-Mrs. W. J. Thompson. 


\section{LETTUCE}

My seed is fresh and can be depended upon to produce a crop of the highest quality, and you will find it true to the name.

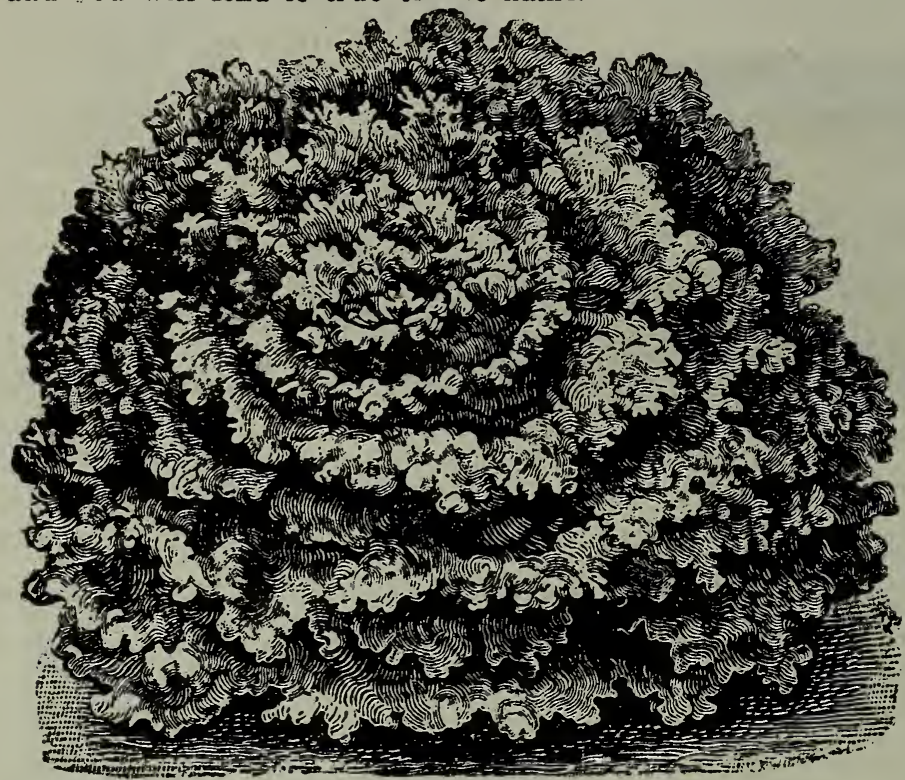

Zimmerman' Earliest Lettuce.

New Early Head-This is an extra early head Lettuce, coming on or about the same time as the Simpson, but produces good sized heads of the finest quality. It gives satisfaction either for forcing in Green House or planting in open ground. The heads are attractive, tender and crisp. My seed of this variety is carefully grown, fresh and of strong germination. This is a very popular variety. It is not only one of the first-class qualities but very attractive. Pkt. 10c; oz. 15c; 1/ lb. $50 \mathrm{c}$; Ib. \$1.75; postpaid.

\section{Zimmerman's Earliest- Extra early, crisp and ten- der. Nothing we have ever offered has given more genuine satisfaction than my Earliest Lettuce. It al- ways comes first, with crisp tenderness which can- not be surpassed. It is not only the Earliest but can} be planted with profit the entire season. The leaves are thin, slightly curled and free from any bitterness. It is very slow to go to seed, remaining tender a remarkably long time. It is very valuable for forcing, also for planting in open ground. Pkt. 5c; oz. 10c: $1 / 4$ lb. $30 \mathrm{c}$; lb. $90 \mathrm{c}$; postpaid.

New Early Crisp Lettuce-This is one of the earliest varieties and you will find it ofrered in my Early-Bird Collection. It stands heat. drouth and also wet weather most remarkably, and can be planted any time during the season, as it is a great all-season Lettuce. Pkt. 5c; oz. 15c; 1/4 lb. 50c; lb. \$1.50; postpaid.

Black Seeded Simpson-This is a well-known market gardener's lettuce. It is one of the best for forcing under glass as well as out-door planting. Pkt. 5c; oz. 10c; 1/4 1b. 25c; lb. $80 \mathrm{c}$; postpaid.

Early Curled simpson-The largest loose-leaved Lettuce, still claimed by many to be the very $\epsilon$ arliest. Leaves are beautifully crimped, tender and sweet; dark green in color. Pkt. 5c; oz. 10c; $1 / 4$ lb. $25 \mathrm{c} ; 1 \mathrm{~b}$. $75 \mathrm{c}$; postpaid.

Crisp-As-Ice-This is the very finest Bronze-Tinged Lettuce; leaves are very tender brittle, glossy, slightly curled and has an attractive green color, with slight tinge of bronze. It produces solid heads of large size and attractiveness. Pkt. $5 \mathrm{c} ; 0 \mathrm{z} .10 \mathrm{c} ; 1 / 4 \mathrm{~b}$ $30 \mathrm{c}$; lb. $80 \mathrm{c}$; postpaid.

Big Boston-The great favorite with truckers and gardeners, and is a fine large head Lettuce. Pkt. 5c; oz. 10c; $1 / 4$ lb. $30 \mathrm{c}$; 1b. $80 \mathrm{c}$; postpaid.

May King-This is an extra early quick-growing variety of the butterhead type Outer leaves have slight brownish tinge, while the heart is a beautiful yellow, very crisp and tender. It is extremely early and of large head. Pkt. 5c; oz. 10c; 1/4 ib. 30c; lb. $80 \mathrm{c}$; postpaid.

Improved Hanson-The most popular variety of the head type. Heads are green outside and white within. Pkt. 5c; oz. 10c; 1/4 lb. 25c; lb. 75c; postpaid.

California Cream Butter-One of the best of the Butter Head varleties. The outer leaves are marked with small brown spots. Crisp and tender and have a rich, buttery flavor. Pkt. 5c; oz. 10c; 1/4 lb. 25c; 1b. 80c; postpaid.

Grand Rapids-This requires less attention than the Black Seeded Simpson and will stand longer after maturity. Pkt. 5c; oz. 10c; 1/4 1b. 25c;1b. $75 \mathrm{c}$; postpaid.

Iceberg-A $n \in w$ variety. but very popular. Leaves are always crisp and tender either in early spring or hottest summer. Pkt. 5c; oz. 10c; 1/4 lb. 25c;1b. 80c; postpaid.

Early Prize Head-Extra early and produces large loose heads. Pkt. 5c; oz. 10c; 1/4 1b. $25 \mathrm{c}$; ib. $75 \mathrm{c}$; postpaid.

Denver Market-An early head Lettuce, the leaves being beautifully marked and blistered. Pkt. 5c; oz. $10 \mathrm{c} ; 1 / 4$ lb. 25c; 1b. $75 \mathrm{c}$; postpaid.

Hard Head-A ready grower; heads hard and firm. Pkt. 5c; oz. 10c; 1// 1b. $75 \mathrm{c}$ postpaid. 


\section{MUSK MELONS}

My Musk melon seed is grown especially for me by experienced melon seed grewers. and $1 \mathrm{~s}$ selected from choice melons. You will find my seed of the highest quality. Do not confuse my high-grade seed with the cheap melon seed sometimes offered by commission houses and others.

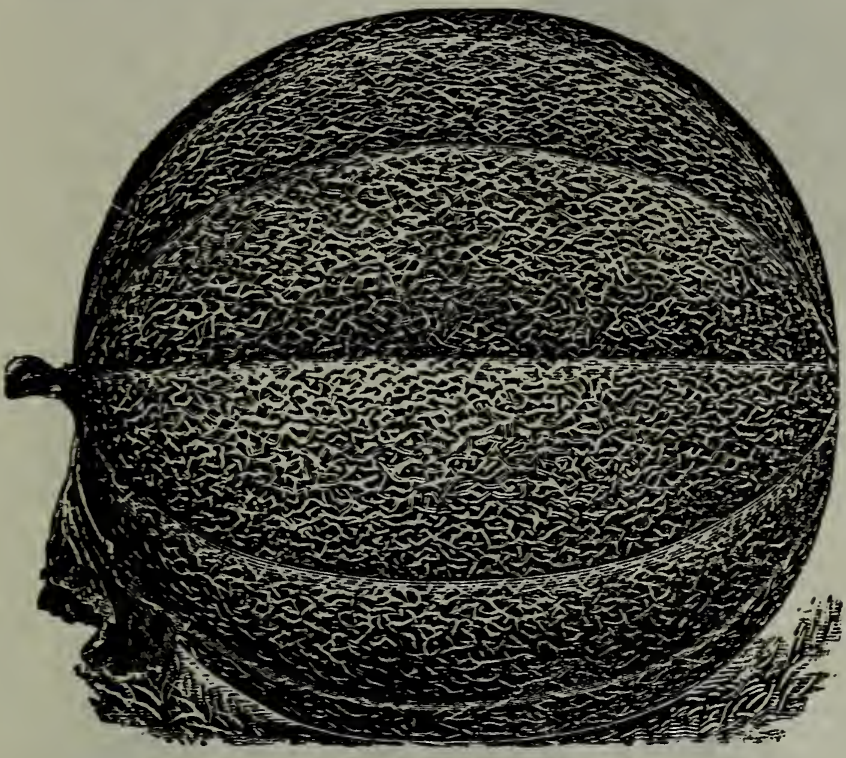

Zimmerman's Best Musk Melon.

Zimmerman's Best-I consider this the very best Muskmelon to be had. The flesh is a ricl orange in the center and edible to the very rind. It is about twice the size of the Rocky Ford and has a very attractive appearance and very sweet. Pkt. $10 \mathrm{c}$ : oz. $15 \mathrm{c} ; 1 / 4$ lb. $50 \mathrm{c}$; $1 / 2$ 1b. $90 \mathrm{c} ; 1 \mathrm{~b}$ 1.75; postpaid.

ZImmerman's Earllest LargeIt is not only the earliest of all but is of good size and of superior quality, which makes it different from the majority of early varieties. Flesh is of a rich orange color, with a small seed cavity and the flavor is excellent. Pkt. 5c; oz. 10c; $1 / 41 \mathrm{~b}$ $30 \mathrm{c}$; 1b. $\$ 1.00$; postpaid.

Extra Early Hackenaack-A very popular market melon. It is 10 days earlier than the ordinary strain of Hackensack. Pkt. 5c; oz. 10c: 1/4 1b. 25c; 1b. $80 \mathrm{c}$; postpaid.

Norfolk Button-An extra earIy melon of the Jenny Lind type. It has green flesh, sweet and spicy. Pkt. 5c; oz. 10c; 1/4 1b. 30c: lb. 90c: postpaid.

Zimmerman's Genuine Rocky Ford-My Rocky Ford seed is planted in every state and territory where melons can be grown, and have never recelved a single complaint. Leading market gardeners send to me every year for seed of this variety rather than save their own seed, because they know that my seed, saved from carefully selected melons of uniform size, will produce the very finest melons. The seed I offer is selected from choice melons only and I guarantee it to have been grown at Rocky Ford, Colo. Pkt. 5c; oz. 10c; 1/4 1b. 30c; 1b. $90 \mathrm{c}$ postpaid.

Extra Early Graud Raplds-This is claimed by many to be the very earliest melon grown. It is exceedingly early, but not of a very good quality. Pkt. 5c; oz. $10 \mathrm{c} ; 1 / 4$ 1b. $25 \mathrm{c}$; 1b. $75 \mathrm{c}$; postpaid.

Zimmerman's Succes-This is a fine melon grown for home or market use. Melons average 6 lbs. in weight and will discount any Rocky Ford ever put on your table. Flesh is light orange and melting rich flavor. Pkt. $5 \mathrm{c}$ oz. $12 \mathrm{c} ; 1 / 4$ Ib. $30 \mathrm{c}$; 1b. $\$ 1.10$; postpaid.

Excelwior Muskmelon-A grand variety. The skin is dark green finely netted; the flesh a rich orange and edible to the rind. Pkt. 5c; oz. 10c; $1 / 4$ lb. 30c; lb. $\$ 1.00$; postpaid.

Improved Montreal Market-The largest

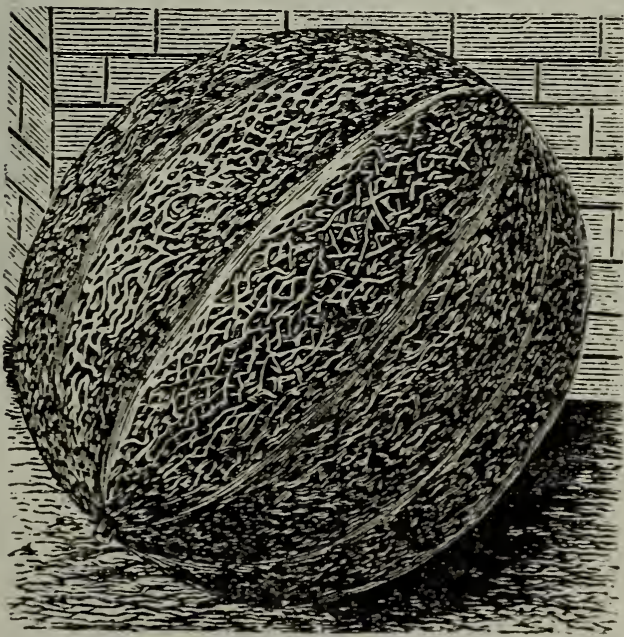
Muskmelon in the world, weighs from 25 to 50

lbs. Skin is green and strongly netted; large, round size and very attractive. Pkt. 5c; oz. $10 \mathrm{c}$ : $/$ lb. $25 \mathrm{c}$; lb. $80 \mathrm{c}$; postpald.

Osage-One of the best melons grown. The flesh is of salmon color, Juicy and sweet. Pkt. $5 \mathrm{c}$; oz. $10 \mathrm{c}$; $1 / 4$ 1b. $25 \mathrm{c} ; 1 \mathrm{~b} .80 \mathrm{c}$; postpaid.

Emerald Gem-The old standard varlety and still popular. Pkt. 5c; 0z. 10c; 1/ 1b $25 \mathrm{c}$; lb. $80 \mathrm{c}$; postpaid.

Giant Chicago Market-One of the largest varieties grown and of good quality. It is also a first-class shipper. Pkt. 5c; oz. 10c; $1 / 6$ 1b. 25c; 1b. 80c; postpaid.

Banana-An entirely distinct variety, bearing lont. slender banana-like irult. Pkt. se: oz. 10c; 1/4 1b. 30e; 1b. 90c; postpaid. 


\section{ONIONS}

My onion seed is fresh and thoroughly tested. Plant only tested Onion Seed.

Ziminerman's Early Globe-An extra early, perfect globe-shaped onion. It is of a real dark red color. Its earliness, together with large size, rich color and perfect globe shape, make it a most desirable onion for both home and market. Pkt. 10c; oz. $=20 \mathrm{c} ; 1 / 4$ lb. 60 c; $1 / 2$ lb. $\$ 1.00$; lb. $\$ 1.90$; postpaid.

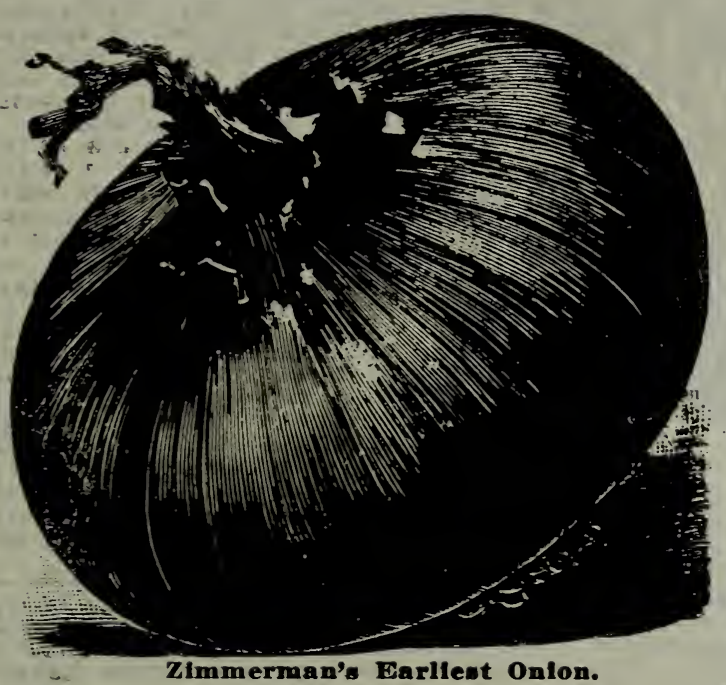

Zimmerman's Earllest-This extra early red onion has been carefully selected and is, I believe, the earliest of onions, being a ti.ifle earlier than my Early Red Globe but is flat. It is of medium size, fine grained, deep red color. They succeed in sold, mucky ground, where others wil fail. Pkt. 5c; oz. 15c; 1/4. 1b. $50 \mathrm{c} ; 1 / 21 \mathrm{~b}$ $90 \mathrm{c}: 1 \mathrm{~b} . \$ 1.75$; postpaid

Yellow Globe Danvers-I offer the earliest strain of Yellow Globe Danvers. They are of uniform large size and command the highest market price. The skin is a rich golden color; flesh is white mild and pleasant flavor. Pkt. $5 \mathrm{c}$; oz. $15 \mathrm{c} ; 1 / 4 \mathrm{lb}$. $45 \mathrm{c}$; $1 / 2$ lb. $75 \mathrm{c}$; ib. $\$ 1.40$; postpaid.

Extra Early Barletta-The earliest white variety, and fine for table use and pickling. Pkt. 5c;07. 15c; $1 / 4$ lb. $50 \mathrm{c} ; 1 / 2 \mathrm{lb}$. $90 c ; 1 b . \$ 1.75$; postpaid.

White Portugal or Silver Skin-A bea utiful standard white onion. They grow to a good size and ripen early and evenly. The flesh is mild and the skin is a clear silvery white. Pkt. 5c; oz. 20c; $1 / 4$ lb. $70 \mathrm{c}$ $1 / 2$ lb. $\$ 1.25 ;$ ib. $\$ 2.40 ;$ postpaid

Southport Red Globe-A perfect globeshaped onion. Rich deep red in color a seeper and of good flavor. Pkt. 5c; oz. 15c; 1/4 lb. 50c; 1/2 1b. $90 \mathrm{c} ; 1 \mathrm{~b} . \$ 1.60$ "4i Sonthport White Globe-Same shape and size as the Red Globe but a pure white color. Flesh is firm and fine grained. Pkt. 5c; oz. 20c; 1/4 lb. $70 \mathrm{c} ; 1 / 2$ 1b. $\$ 1.25 ; 1 \mathrm{~b}$. $\$ 2.40$ postpaid.

Southport Yellow Globe-Same shape as Red and White Globe, but is of a straw color; excellent keeper and sells readily on the market. Pkt. 5c; oz. 15c; 1/4 1b. 50c; 1/2 lb. $90 \mathrm{c}$; lb. $\$ 1.60$; postpaid.

American Prize-Taker-This is, a splendid variety nf the celebrated fancy Spanish Onions. They grow to an enormous size, as some have been known to weigh $51 / 2$ pounds each. Flesh pure white, fine grained, mild and delicate in flavor. Pkt. $5 \mathrm{c} ; 0 \mathrm{z}, 15 \mathrm{c} ; 1 / 4 \mathrm{~b}$. $45 \mathrm{c} ; 1 / 2$ lb. $75 \mathrm{c} ; 1 \mathrm{~b}$. $\$ 1.40$; postpaid.

Large Red Wethersfield-I have an unusually heavy niarket-gardener trade on this seed, which more than doubled last year-proof of the superior quality of MY ONION SEED. The skin is of a deep purplish red, flesh white and moderately fine grained. Pkt. $\mathrm{c}$; oz. 15c; $1 / 4$ lb. $45 \mathrm{c}$; $1 / 2$ lb. $80 \mathrm{c}$; lb. $\$ 1.50$; postpaid.

Mammoth Silver King-A large purg white onion, grows from 5 to 8 inches in size. The skin is a beautlfully silvery white, while the flavor is very mild and sweet. Pkt. $5 c$; $0 \%$. $15 \mathrm{c}$; $1 / 4$ 1b. $50 \mathrm{c}$; $1 / 2$ lb. $90 \mathrm{c}$; lb. $\$ 1.75$; postpald.

Australian Brown-A good keeper, fine in the market. The color a pale reddish brown and of good quality. Pkt. $5 \mathrm{c}$; oz. $15 \mathrm{c} ; 1 / 4$ lb. $45 \mathrm{c} ; 1 / 21 \mathrm{~b} .80 \mathrm{c} ; 1 \mathrm{~b}$. $\$ 1.50$; postpaid.

White Bermuda-My seed of this variety is as pure as can be obtained and is direct from Tenerife, one of the Canary Islands and the home of the Bermuda Onions. They are of large size, mild and easily cultivated. Pkt. $5 \mathrm{c} ; 0 \mathrm{z}, 20 \mathrm{c} ; 1 / 4 \mathrm{~b}, 75 \mathrm{c} ; 1 / 21 \mathrm{~b}$. $\$ 1.40 ;$ lb. $\$ 2.75$; postpaid.

Red Bermuda-The same form, size and description as the White Bermuda. The difference only in color. Pkt. $5 \mathrm{c} ;$ oz. $20 \mathrm{c} ; 1 / \mathrm{lb}$. $70 \mathrm{c} ; 1 / 2 \mathrm{lb}$. $\$ 1.30$; lb. \$2.50; postpald.

\section{Zimmerman's Select Onion Sets}

I watch the "Onion Set Question." I have to. I have a fine lot of sets this year.just as fine as you $\in$ ver saw; no "culls" in them.

Yellow Bottom Sets-Pt. 15c; qt. 25c; postpald. By, express or freight, peck 80c; bu. $\$ 3.00$

Red Bottom Sets-Pint 15c; qt. 25c; postpaid. By express or freight, peck $85 \mathrm{c} ; \mathrm{bu}$. $\$ 3.20$ White Bottom Sets-Pint 15c; qt. 25c; postpaid. By express or freight, peck 95c bu. $\$ 3.50$

Zimmerman Se€d Coinpany:

Hazelton, Kan, Feb. 18, 1911

I was well pleased with the seeds I received last year.-W. F. Burns. 


\section{PEAS}

are very scarce this yoar; good seed is exceedingly hard to secure. I had to pay am extra high price to zet sood stock, but I bought it. Look out for old peas this year. Beware of the "Cheap." I could have bought some "Low Priced" seed, but I didn't. I don't bandle that kind. Varietie marked are wrinkled.

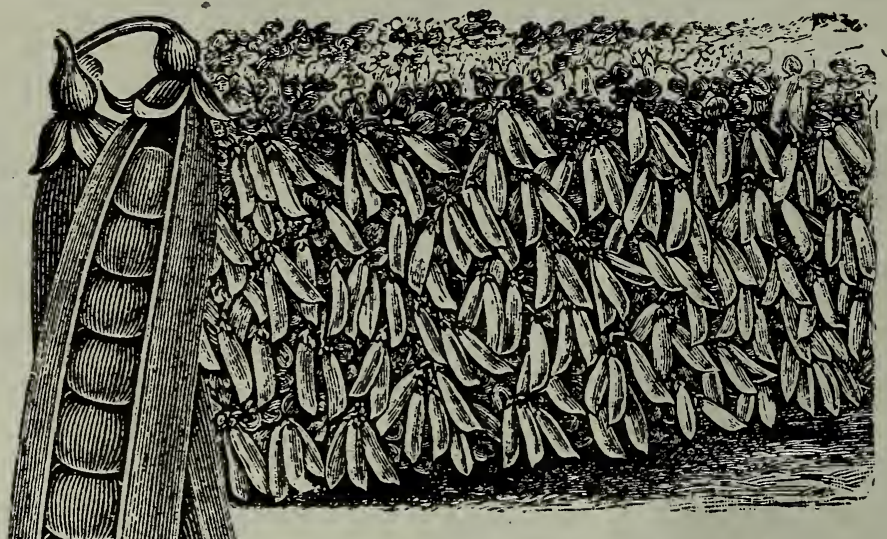

Early Winner Pea.

* Z i m m e r m a n', Early Winmer-The name suggests the pea. It is certainly a winner. I secured a small tock of this last season too late for my catalogue, but made a special offer late in the season. I consider this pea one of the finest vegetables I have over introduced. It is nearly as early as the Alaska or First and Best, but is wrinkled and about as large as any of the late varieties It bears continuously throughout the season and is a heavy bearer at that. Just think of $1 \mathrm{t}$ a large wrinkled pea, an everbearer and as early as the smooth varieties. In flavor it is unsurpassed by

any. Pea seed is very searce this year and I have only a limited stock of this variety and will advise ordering early. Pkt. $10 \mathrm{c} ; 1 / \mathrm{pt}$. $25 \mathrm{c}$; pt. $40 \mathrm{c}$; qt. $70 \mathrm{c}$; postpaid. By express or freight, $4 \mathrm{qts} \$ 1.75$, pk. $\$ 3.25$.

Two Weeks Early-I am still offering my Two Weeks Early as the earliest pea in the world. I have never been able to find one that will equal it for yield or regularity of growth, quality and productiveness. It is a smooth variety, but of fine flavor. Vines grow 18 inches high and are loaded with these delicious peas. This pea has more than filled the claim I have made for it. It will make a crop where others fail, and will be the first in the market. Wherever planted, they have never falled to bear abund. antly and are the first. They are not an ever-bearing pea, but produce a large crop and mature uniformly and the space can be used for some other vegetable. Pkt. 5e; is pt. 200; pt. 30c; qt. 50c; postpaid. By express or freight. 4 qts. $\$ 1.30$; pk. \$2.50.

*Little Gem-The old variety and very popular. Pkt. 5c; 1/2 pt. 20c; pt. 30c; qt. 50c; postpaid. By express or freight, 4 qts. $\$ 1.50 ; \mathrm{pk}$. $\$ 2.90$.

* Gradus or Prosperity-An early wrinkled pea, of large size and a great favorite with market gardeners. Produces long pods 3 to 5 inches in length, contains 8 to 10 peas. Pkt. 5c; 1/2 pt. 20c; pt. 35c; qt. 60c; postpaid. By express or freight, 4 qts. \$2.00; pk. \$3.20.

Alaska-An extra early pea and very popular, pods are well filled with smoth peas. Pkt. 5c; $1 / 2$ pt. $20 \mathrm{c}$; pt. 30c; qt. 50c; postpaid. By express or freight, 4 qts. \$1.25; pk. \$2.50.

First and Fest-An extra early smooth pea. Pkt. 5c; 1/2 pt. 20c; pt. 30c; qt. 50c; postpaid. By express or freight, 4 qts. $\$ 1.25 ;$ pk. $\$ 2.50$.

- American Wonder-A very popular early variety, grows about 6 inches in height. Pkt. 5c; 1/2 pt. 20c; pt. 30c; qt. 50c; postpaid. By express or freight, 4 qts. \$1.50; pk. \$2.00.

*Nott's Axcelsior-One of the very best Dwarf wrinkled peas in cultivation and produces pods 3 inches in length, containing 7 to 9 large wrinkled peas. Pkt. 5c; 16 pt. 20c; pt. $30 \mathrm{c}$; qt. \$50c; postpaid. By €xpress or freight, 4 qts. $\$ 1.50 ; \mathrm{pk}$. \$3.00.

*Imp. Stratagem-An excellent wrinkled pea, grows about 24 inches high, very vigorous and productive, and is a great favorite with market gardeners. Pods are oxtra large and well filled. Pkt. $5 \mathrm{c} ; 1 / 2 \mathrm{pt}$. $20 \mathrm{c}$; pt. $30 \mathrm{c} ; \mathrm{qt}$. $45 \mathrm{c}$; postpald. By express or fred ght, 4 qts. $\$ 1.50 ;$ pk. $\$ 3.00$.

* Blims. Everbearing-Vines grow 18 to 20 inches in height. Pods 3 to 5 inches long. Well fllled. It has a pecullar branching habit, forming as high as 10 stalks from a ingle root. Pkt. 5c; 1/2 pt. 20c; pt. 30c; qt. 59c; postpaid. By express or freight, 4 qts. $\$ 1.25 ;$ pk. $\$ 2.50$.

*Telephone-One of the largest peas grown. Vines srow $4 \mathrm{ft}$ high and are filled with large pods containing 8 to 10 peas of goud size and flavor. This is a most excellent pole or stick pea. Pkt. 5c; $1 / 2$ pt. 20c; pt. 30c; qt. 50c; postpaid. By express or i'reiglit, 4 qts. $\$ 1.50 ;$ pk. $\$ 3.00$.

* Chambinn of Lingland-A well known late variety heing one of the best tall peas. Pkt. $\bar{c}$; $1 / 2$ pt. $20 \mathrm{c}$; pt. 30c; qt. 50c; postpaid. By express or freight. 4 yts. \$1.30; pk. \$2.00.

lvbite Marrowfut-An old standard smooth pea. Grows about $4 \mathrm{ft}$. high. Pkt. 5c; $1 / 2$ pt. $12 \mathrm{c}$; pt. $20 \mathrm{c}$; qt. 35c; postuaid. By express or freight, 4 qts. $75 \mathrm{c} ; \mathrm{pk}$. $\$ 1.40$

Notice-While seed peas were scarce this year, I have the finest stock obtainable. sume old peas will probably be offered at a low price. Plant only fresh new seed -1 have it.

My peas are ot up in dry measure pints and quarts, about 1/s pint per quart more than the measures generally used. 


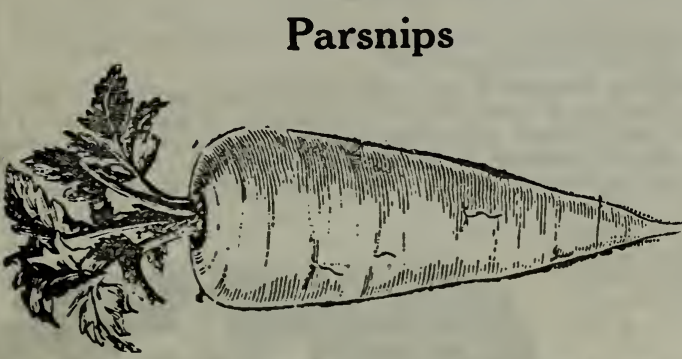

Hollow Crown Sugar or long Smooth-The oldest and one of the best varieties grown. White, sweet and tender Pkt. 5c; oz. 8c; $1 / 4$ lb. $15 \mathrm{c}$; $1 / 2$ 1b. $-25 \mathrm{c}$; 1b. $40 \mathrm{c}$; postpaid.

Guernser-The roots are short, ending abruptly with a small tap root. Pkt. 5c; oz. 8c; $1 / 4$ 1b. $15 \mathrm{c}$; $1 / 2$ 1b. $25 \mathrm{c}$; $1 \mathrm{~b}$. $40 \mathrm{c}$; postpaid.

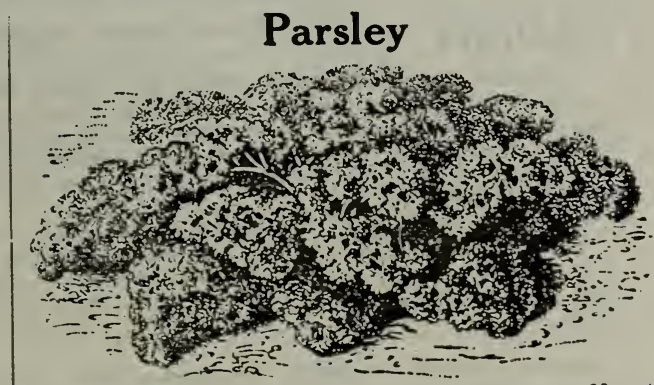

Champion Moss Curled-An excellent variety, the leaves are finely curled and of a dark green color. Pkt. 5c; oz. $8 \mathrm{c}$ : $1 / 4$ lb. $20 \mathrm{c}$; $1 / 2$ lb. $35 \mathrm{c}$; 1b. 60c; postpaid.

New Emerald-The plants are dwarf and compact. Pkt. 5c; oz. 8c; $1 / 41 \mathrm{~b} .20 \mathrm{c} ; 1 / 2$ lb. $35 \mathrm{c} ; 1 \mathrm{~b} .60 \mathrm{c}$; postpaid.

\section{Pumpkins}

Thanksgiving Pie Pumpkin-The finest and sweetest of all Pumpkins. I have been offering this variety for several years and have found none to equal it. They are not large, but just the proper size for easy handling and their quality is unsurpassed. If you like pumpkin pies, just plant some of this and you will be more than pleased. They are of an orange yellow and the flesh is fine grained. Pkt. 5c; oz. 10c; 1/4 1b. 20c; 1b. $60 \mathrm{c}$; postpaid.

Small Sugar-The old favorite Pumpkin. Pkt. 5c; oz. 8c; 1/4 1b. 20c; 1/2 1b. $35 \mathrm{c} ; 1 \mathrm{~b}$. 55c; postpaid.

wiuter Luxury-Very productive, fine gained, a golden russet color and excellent keeper. likt. 5c; oz. 8c: 1/4 lb. 20c; 1/2 lb. 35c; lb. 55c; postpaid.

Fing of the Iron, Mammoth Yellow It is the largest pumpkin grown, averaging from 100 to $200 \mathrm{lbs}$. Flesh fine grained and has an orange yellow skin. Pkt. 5c: oz. 15c; $1 / 4$ lb. 40c; 1/2 1b. $75 \mathrm{c}$; 1b. $\$ 1.25 ;$ postpaid.

and small and in one end while the large neck is solid meat Pkt $\mathrm{c} ; 0 \mathrm{z}, 10 \mathrm{c} ; 1 / 1 \mathrm{~b}, 25 \mathrm{c} ; 1 / \mathrm{g}$ lb. $40 \mathrm{c} ; 1 \mathrm{~b}$. $75 \mathrm{c}$; postpaid. Chere Pumpkin-This is a very good and well known variety. Good for private

gardening and stock. Pkt. 5c; oz. 8c; $1 / 4$ lb. 20c; 1/2 lb. 35c; lb. 60c; postpaid. $\mathrm{Pkt}$. 5c; oz. $8 \mathrm{c}$; $1 / 41 \mathrm{~b}$. $15 \mathrm{c} ; 1 / 2$ lb. 25c; 1b. $40 \mathrm{c}$; postpaid.

Caxhe or-Sometimes called Crooked neck. $60 \mathrm{c}$; posti aid.

Tenueixee Sweet Potato-Medium size and creamy white color; fine for cooking. Pkt. 5c: $07.10 \mathrm{c} 1 / 4$ lb. $25 \mathrm{c} ; 1 / 2$ lb. $40 \mathrm{c} ; 1 \mathrm{~b}$. $75 \mathrm{c}$; postpaid.

\section{Choice Peppers}

The New Mammoth- The largest and finest large as Procopp's Giant and mild as the Ruby King. ness. They are very shy seeders, which makes the seed scarce. Include a packet in your order. Pkt. 5c; $1 / 2$ oz. 10c; oz. 20c; 1/4 lb. 70c; postpaid.

Ruly ling-A large red variety and exceedingly mild and sweet. Pkt. 5c; $1 / 2$ oz.

10c: $0 \%$ 15c: 1/4 lb. 50c: postpaid.

Celential-Lp to maturity they are a rich creamy yellow, turning to a bright scarlet when ripe. Pkt. 5c: 1/207. 12c: 0z. 20c: 1/4 lb. 60c; postpaid.

Brocopy riant-This has long been the giant of the pepper family. Peppers are from $T$ to 9 inches long and just enough to be pleasant to the taste. Pkt. 5c; / $02.12 \mathrm{c}$ : oz. $20 \mathrm{c} ; 1 / 4$ lb. $60 \mathrm{c}$; postpaid.

Larze liell or sweet spanish-Suitablefor filling with cabbage, etc., and for mixed pickles. $\Gamma \mathrm{kt}$. $5 \mathrm{c}$; 1/207. 12c; oz. $20 \mathrm{c} ; 1 / 4$ lb. 50c; postpaid.

Folilen Dawn golden yellow, making them very attractive. Pkt. 5c; $1 / 2$ oz. 10c; oz. 20c; 1/4 Ib. 50c; postpaid.

Chluere ciant-Double the size of Ruby King and is early, notwithstanding its large size: flesh is mild and unusually thick. Pkt. $10 \mathrm{c} ; 1 / 2$ oz. $25 \mathrm{c}$; oz. $40 \mathrm{c} ; 1 / 4$ lb. $\$ 1.25$; postpaid. Long cnyenue- The old popular red variety; flesh is strong and hot. Pkt. 5c; $4 / 20 z$. $10 \mathrm{c}: 0 \% 15 \mathrm{c}: 1 / 4$ lb. $50 \mathrm{c}$ : post paid.

Chill-True Chili pepper; small and very hot. Pkt. 5c; 1/2 oz. 10c; oz. 20c; 1/ 1b. 60c; postraid.

\section{Salsify or Vegetable Oyster}

Mammoth Sandwich Imland-The very best variety grown. Pkt. 5c; oz. 10c; 1/4 1b. $35 \mathrm{c}$; $1 / 2$ lb. $60 \mathrm{c} ; \mathrm{lb}$. $\$ 1.00$; postpaid.

\section{Spinach} New Long Standiag-The best and most popular variety grown. Leaves are large,
thick and crumpled. Pkts. 5c; oz. 6c; $1 / 4$ lb. 12c; 1/2 1b. 20c; 1b. 35c; postpaid. lound

1/2 1b. $20 \mathrm{c}$; $1 \mathrm{~b}$. $35 \mathrm{c}$; postpaid.

Bloomedale or Savos Leaved-The market gardener's favorite. Pkt. 5c; oz. 6c; 1/4 1b.

12c; $1 / 2$ lb. $20 \mathrm{c}$; $1 \mathrm{~b}$. $35 \mathrm{c}$; postpaid

with light straw protection. Pkt.

Ec: 0z. 6c; $1 / 6$ lb. 12c: $1 / 2$ lb. 20e; 1b. 36c; ostbald. 
RADISH

My Radish seed is strictly. French grown which is acknowledged to be the very best; fresh and of strong germination.

Early Scarlet Crisp-This is a new variety which I secured late last season. If you were fortunate enough to secure some of the seed last year you know what it is. I do not hesitate to state that this is one of the very best radishes on the market. It is of medium size, dark red, grows rery quickly, which makes it crisp and brittle. Try a packet $o:$ more on my recommendatiou; you will be pleased. Pkt. 10c; oz. 15c; 1/4 lb. $10 \mathrm{c}$; $1 \mathrm{~b}$. $\$ 1.50$; postpaid.

New Lightning-I first offered this radish seed several years ago as one of the best in the early market. It is a beautiful variety; dark red in color and round in shape, and is the earliest in the world. Pkt. $5 \mathrm{c} ;$ oz. $10 \mathrm{c} ; 1 / 4$ lb. $25 \mathrm{c} ; 1 / 2$ 1b. $40 \mathrm{c} ; 1 \mathrm{~b} .75$; postpaid.

Early White Turnip Shaped-Very early and a clear pure white; mild, sweet flavor. It is also good for forcing. Pkt. $5 \mathrm{c} ; 0 \mathrm{z} .10 \mathrm{c} ; 1 / 41 \mathrm{~b} .20 \mathrm{c}$; 1/6 ib. $35 \mathrm{c}$; 1b. $60 \mathrm{c}$; postpaid.

Early Scarlet Globe-Very early, mild, crisp and tender. Pkt. 5c; oz. 10c; 1/4 1b. 20c; 1/2 1b. 35c; lb. $60 \mathrm{c}$; postpaid.

Crimson Giant-A radish reaching a large size, without getting hollow or pithy. Pkt. 5c; oz. 10c; $1 / 4$ lb. $20 \mathrm{c}$; $1 / 2$ lb. $35 \mathrm{c}$; 1b. $60 \mathrm{c}$; postpaid.

French Breakfast-An old favorite breakfast radish. Dark red with white tip. Olive shape. Pkt. $5 \mathrm{c}$; oz. 10c; $1 / 4$ 1b. $20 \mathrm{c}$; $1 / 230 \mathrm{c} ;$ ib. $50 \mathrm{c}$; postpaid.

New Leafless-A fine radish and attracts attention both on the market and in the garden. Bright scarlet, olive shape, very tender, and very few leaves. Pkt. 5c; oz. 10c; $1 / 61 \mathrm{~b}$. 20c; 1/8 1b. 40c; lb. $75 \mathrm{c}$; postpaid.

Early White, olive shaped-It is crisp, tender and a great favorite and is one of the very finest radish $\in$ s on the market. It is a handsome pure white variety. Pkt. 5c; oz. $10 \mathrm{c}$; $1 / 6$ 1b. 20c; 1/8 $1 \mathrm{~b}$. $30 \mathrm{c}$; 1b. $50 \mathrm{c}$; postpaid.

Rosy Gem-One of the earliest varieties in cultivation. Deep red at top and white at bottom. One of the earliest varieties in cultivation. Pkt. 5c; oz. $10 c ; 1 / 4$ 1b. 20c; $1 / 2$ 1b. $30 c ; 1 b .50 c ;$ postpaid.

White Strasburg-Roots are oblong, both skin and flesh pure white, flesh firm, crisp and tender and retains these qualities even when old. Pkt. $5 \mathrm{c}$;

oz. $10 \mathrm{c} ; 1 / 4$ lb. $20 \mathrm{c}$; $1 / 2$ lb. 30c; $1 \mathrm{~b}$. 50c; postpaid.

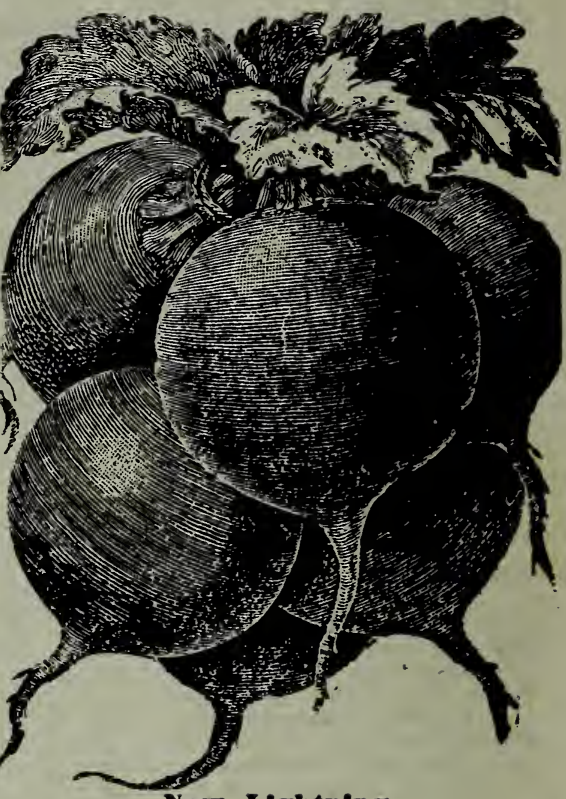

New Lishtning.

Early Scarlet White Tipped-For out-door culture. It is in great demand by the most critical growers, and we have the finest stock. Pkt. 5c; 0z. 10c; 1/4 1b. 20c; 1/2 1b. 30c; 1b. 50c; postpaid.

New Larly Giant-An extra early variety of large size and of fine flavor. Criwp and tender. Never gets pithy. Almost aw early as the earliest and twice the wize. Pkt. 5e; oz. 10c; $1 / 4$ lb. 25e; $1 / 2$ lb. $40 \mathrm{c} ; 1 \mathrm{~b}$. 75c; postpaid.

New White Iclele-Pure white, long, slender and the earliest of the long white radishes. The finest white variety in the world. Pkt. 5c; 0z. 10c; 1/4 1b. 20c; 1/2 1b. $85 \mathrm{c} ; 1 \mathrm{~b}$. $60 \mathrm{c}$; postpaid.

Chartiers-Long scarlet white tipped, tender and mild. Pkt. 5c; 0z. 10c; 1/4 1b. 20c; $1 / 2$ 1b. 35c; lb. $60 \mathrm{c}$; postpaid.

Long Scarlet Short Top-This has been the standard long variety for many years and is a favorite today. Pkt. 5c; $1 / 41 \mathrm{~b} .20 \mathrm{c} ; 1 / 21 \mathrm{b.35c} ; 1 \mathrm{~b} .60 \mathrm{c} ;$ postpaid.

New White Chinese-One of the very best large white winter varieties. Pkt. 5c: $1 / 6$ $20 \mathrm{c} ; 1 / 2$ 1b. $35 \mathrm{c}$; 1b. $60 \mathrm{c}$; postpaid.

Califoruia Mammoth Winter-An extra large, fine variety. They grow from 8 to

12 inches long and of perfect shape. Pkt. 5c;1/4 1b. 20c; 1/2 1b. 35c; 1b. 60c; postpald.

Long Black Spanish-A favorite winter radish and an excellent keeper. Pkt. 5c; $1 / 6$ lb. $20 \mathrm{c} ; 1 / 2$ lb. $35 \mathrm{c} ; 1 \mathrm{~b}$. $60 \mathrm{c}$; postpaid.

\section{Squash}

Warty Hubbard-This is the ldeal Hubbard for home and market use. Very sweet and superior to the other varieties. Pkt. $5 \mathrm{c} ; 0 \mathrm{oz} .10 \mathrm{c} ; 1 / 4 \mathrm{lb} .25 \mathrm{c} ; 1 / 2 \mathrm{lb}$. $45 \mathrm{c} ; 1 \mathrm{~b}$. $80 \mathrm{c} ;$ postpald. Imp. Mammoth Hubbard-A select atrain of the celebrated Hubbard Squash and noted for its immense size. Pkt. $5 \mathrm{c}$; oz. $10 \mathrm{c}$; $1 / \mathrm{t} 1 \mathrm{~b} .25 \mathrm{c} ; 1 / 21 \mathrm{~b} .45 \mathrm{c} ; 1 \mathrm{~b}$. 80c; postpaid.

Golden Hubbard-Deep orange-yellow; very attractive fine grained, cooks well and is of superior flavor. Pkt. 5c; oz. $10 \mathrm{c} ; 1 / \mathrm{h}$ lb. $20 \mathrm{c} ; 1 / 21 \mathrm{~b}$. $35 \mathrm{c} ; 1 \mathrm{~b}$. $60 \mathrm{c}$; postpaid.

Mammoth White Buwh Scallop-Known through the south as "Cymling." Pkt. 5c; oz.

$10 \mathrm{c} ; 1 / \mathrm{s}] \mathrm{b} .20 \mathrm{c} ; 1 / 2$ lb. $35 \mathrm{c} ; 1 \mathrm{~b} .60 \mathrm{c} ;$ postpaid.

Pike' Peak or Sibley-Skin if smooth greenish gray eolor. Pkt. 5e; ea. $10 \mathrm{c} ; 1 / \mathrm{s}$ ib.

20c; $1 / 2$ lb. $35 \mathrm{c}$; $1 \mathrm{~b}$. $60 \mathrm{c}$; postpaid.

Marblehead-About the size of the Hubbara and hell of bluah-sroen. Pkt. 5c: oz.

$10 \mathrm{c} ; 1 / 4$ 1b. $25 \mathrm{c} ; 1 / 6$ 1b. $45 \mathrm{c} ; 1 \mathrm{~b}$. $80 \mathrm{c}$; postpaid.

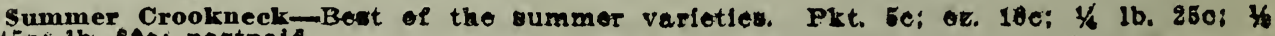

1b. 45e; 1b. soe; poutpaid:

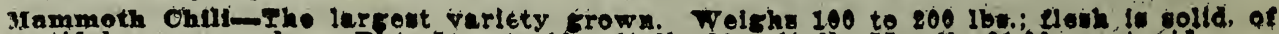

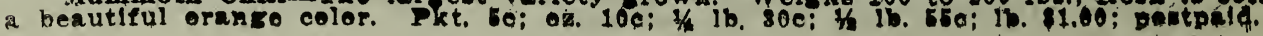




\section{TOMATOES}

My tomato seed is grown by the most skilleul growers in the world, and is not to be confused with the cheap seed secured from canneries, commission houses, etc. You will find my descriptions accurate and reliable.

New Crimson Ball-An extra early fine tomato, perfectly round, smooth as an apple und of beautiful crimson color, hence its name "Crimson Ball." it is not only extra early but in a continuous bearer. Ir weed is limited and I cannot fill large orders. See llintration on back cover. Pkt. 10e; $1 / 2$ oz. 20c; oz. 40e; $1 / 4$ lb. 81.40 ; postpaid.

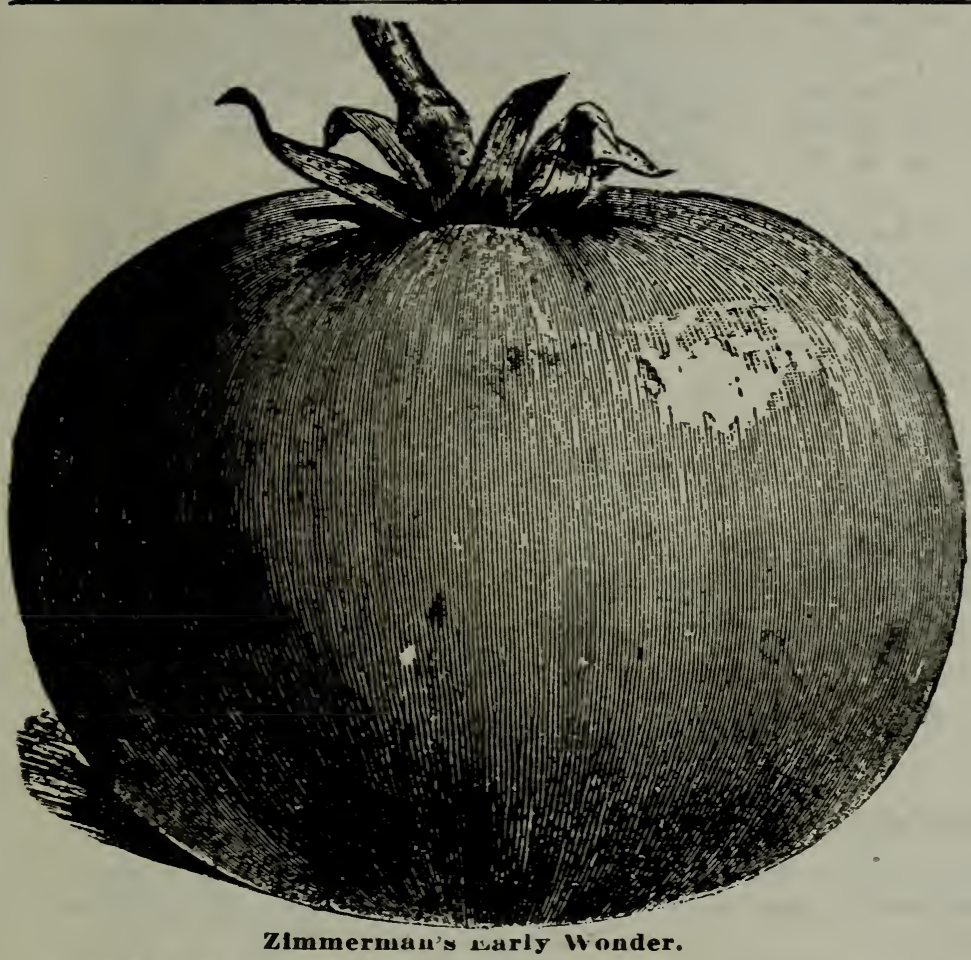

Zimmerman's E a r ly Wo n d r Tomato-The earliest tomato in the world. I have been of fering this varlety for $g$ years. It is perfectly smooth, round and of rich red color. The earliness and handsome appearance $m a k \in S$ it the grandest tomato ever introduced. The demand for this variety has been so great the past two seasons that my supply of seed was exhausted before the season was half over. I introduced this tomato in 1902. Pkt. $5 \mathrm{c}$; $1 / 2$ oz. $20 \mathrm{c}$; oz. $35 \mathrm{c}$ $1 / 4$ 1b. $\$ 1.25$; postpaid. June Pink-Extra early pink-fruited variety and absolutely blightproof. They stand shipping well. Pkt. 5c; $1 / 2$ Oz. 10c; oz. $20 \mathrm{c} ; 1 / 4$ ib $60 \mathrm{c} ; 1 / 2$ lb. $\$ 1.10 ; \quad \mathrm{lb}$ $\$ 2.00$; postpaid.

Earliana-An e $x+r a$ early variety, the favorite with market gardeners. Pkt. $5 \mathrm{c} ; 1 / 2$ oz. $12 \mathrm{c}$; oz. $20 \mathrm{c}$; 1/4 lb. $70 \mathrm{c}$; postpaid. Chalk's Early Jevrel-A grand tomato and a favorite with gardeners. Large and very
meaty. Pkt. 5c; 1/2 oz. 10c; oz. 20c; 1/4 1b. 60c; 1/2 1b. $\$ 1.10 ;$ postpaid.

Zimmerman's Improved Tree Tomato-The very finest of the tree tomatoes and earlie than the varieties generally offered. Fruit is round, few seeds, solid and excellent flavor. Pkt. 5c; $1 / 2$ oz. $15 \mathrm{c} ;$ oz. $25 \mathrm{c} ; 1 / 4$ lb. $80 \mathrm{c}$; postpaid.

Magnus-A handsome large potato-leaved variety; ripens evenly. Pkt. $5 \mathrm{c} ; 1 / 2 \mathrm{oz} .12 \mathrm{c} ;$ oz. $20 \mathrm{c} ; 1 / 4$ lb. $60 \mathrm{c}$; postpald.

Paragon-Large, solid, smooth tomato; deep red. Fkt. 5c; 1/2 oz. 12c; oz. 20c; $1 / 4$ 1b. $60 \mathrm{c}$; postpald.

Kansas Standard-Potato-leaved tomato and produces fruit in clusters. Vines grow three feet high. Is an extra good keeper and is a good shipper. Pkt. $5 \mathrm{c} ; 1 / 2 \mathrm{oz}$. $15 \mathrm{c} ; 0 \mathrm{oz}$ $25 \mathrm{c} ; 1 / 41 \mathrm{~b}$. $75 \mathrm{c}$; postpaid.

Matchless-This is the old favorite market gardener tomato; very large size and uniform; good keeper. Pkt. 5c; $1 / 2$ oz. $10 \mathrm{c} ; 0 z .20 \mathrm{c} ; 1 / 4$ lb. $60 \mathrm{c}$; lb. $\$ 2.00$; postpaid.

Ponderona-Very large purple varlety; solld and with few seeds. Pkt. 5c; 1/2 1b. $15 \mathrm{c}$ oz. $25 \mathrm{c}$; $1 / 6$ 1b. $90 \mathrm{c}$; 1b. $\$ 2.50$; postpald.

Golden Queen-A large yellow varlety of superfor flavor. Pkt. 5c; 1/2 oz, 10c; oz, 20c; /6 lb. 60c; postpaid. Red Pear-Fruit small and pear shape. Fine for preserving and plckling. Pkt. $5 \mathrm{c} ; 1 / 2$
oz. 10c; oz. 20c; 1/4 lb. $60 \mathrm{c}$; postpaid. Yellow Pear-Same as the Red Pear except in color. Pkt. 5c; 1/2 0z. 10c; oz. 20c; 1/4
1b. postpaid.

WESTERN GIANT-This is absolutely the largest tomato in the world. They are simply tremendous and the quality is excelleut. Ked, solid and very meaty. Plant some of my seed and see what grand tomatoes you get. Pkt. 5e; $1 / 2$ oz. 15e; oz. 25e; $1 / 41 \mathrm{~b}$. 80c;
postpaid.

Beauty-Smooth tomato, purple variety. Pkt. $5 \mathrm{c} ; 1 / 2$ oz. $10 \mathrm{c} ; 0 \mathrm{z} .20 \mathrm{c} ; 1 / 41 \mathrm{~b} .60 \mathrm{c} ; 1 \mathrm{~b}$ \$2.00; postpaid.

Acme-Purplish red tomato. Pkt. 5c; 1/6 oz. 10c; 08. 20c; 1/ 1b. 60c; 1b. \$2.00; postpaid.

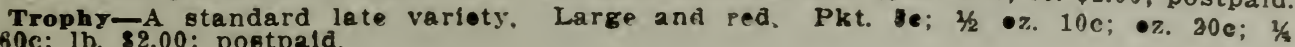
Ib. $60 \mathrm{c}$; 1b. $\$ 2.00$; postpald. 


\section{Garden Turnips}

Golden Jelly-A delicate flavored yellow variety; flesh crisp and firm. Most excellent for table use. Roots medium size, round and very smooth. It is an excellent keeper. Pkt. 5 c; oz. 10 c; $1 / 4$ lb. 25c; lb. 75 c; postpaid.

Early White Milan-The earliest of all. It is a beautiful pure white. The foliage is scant and short. Both the skin and flesh are snowy white. Pkt. 5c; oz. 10c; $1 / 4$ lb. 25c; lb. $75 \mathrm{c}$; postpaid.

Purple Top Milan-A popular variety and a good early turnip. It is smooth with a purple top. Pkt. 5 c; oz. 10c; $1 / 4$ lb. 25c; lb. $75 \mathrm{c}$; postpaid.

Early Flat Dutch-An extra early turnip of good size. Pkt. 5c; oz. 10c; $1 / 4$ lb. 20c; lb. 50c; postpaid.

Purple Top Strap Leaved-The standard purple-top variety; good flavor; fine grained and a good keeper. Pkt. 5c; oz. 10c; $1 / 4$ lb. 20c; lb. 50c; postpaid.

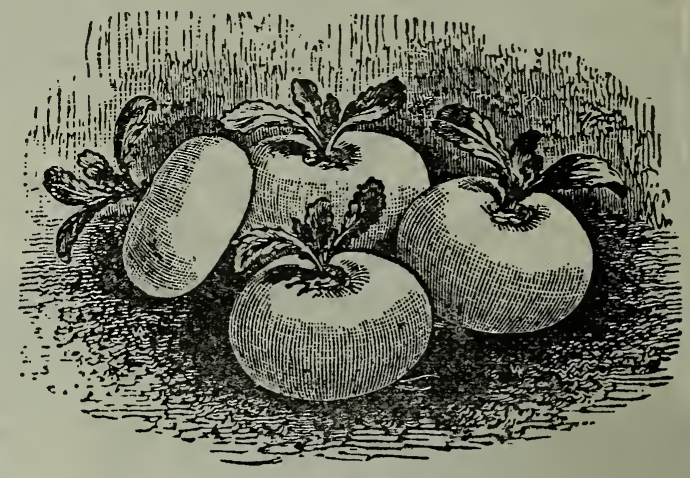

White Milan.

White Egg-A rapid grower. Egg-shaped white variety. Pkt. 5c; oz. 10c; 1/4 lb. 20c; lb. $50 \mathrm{c}$; postpaid.

Large White Globe-A free growing turnip, suitable for table and stock. Pkt. 5c; oz. $10 \mathrm{c} ; 1 / 4$ lb. 20c; lb. 50c; postpaid.

Cow Horn-Grows long; is an excellent cooking turnip. Pkt. 5c; oz. 10c; 1/4 1b. 20c; lb. 50c; postpaid.

Seven Top-Cultivated for the tops which are used for greens. Pkt. 5c; oz. 10c; 1/4 lb. 20c; lb. 50c; postpaid.

\section{Rutabaga or Swede Turnips}

Zimmerman's Heavy Cropper-This is the King of Swede turnips. The heaviest, hardiest, best shaped and most productive. Flesh is rich yellow and fine flavor. Pkt. 5c; oz. $10 \mathrm{c} ; 1 / 4$ lb. 20c; lb. 50c; post paid.

Mammoth Red Top Globe-A free growing variety and useful for both table and stock. Pkt. 5c; oz. $8 \mathrm{c}$; $1 / 4$ lb. $15 \mathrm{c}$; lb. $45 \mathrm{c}$; postpaid.

Improved American Purple Top-Yellow flesh. One of the best varieties for table and stock feed. Pkt. 5c; oz. 8c; $1 / 4$ oz. 15c; lb. 45c; postpaid.

Zimmerman Seed Company:

Trousdale, Okla., March 19, 1911.

I was so well pleased with the few seeds I bought from you last year I am sending you my order now.-Mrs. B. A. Meinert.

Zimmerman Seed Company:

Groom, Texas, March 27, 1911.

Seed corn received and I am well pleased with it.-Henry Kihler.

Zimmerman Seed Company:

Eutaw, Alabama, Feb. 10, 1911.

I wish to thank you for the seed just received and also for your kindness in filling order so accurately.-Very truly yours, Edward Brodnax.

Zimmerman Seed Company:

Manchester, Okla., Feb. 14, 1911.

I think your seeds are the very best.-Mrs. May Powers.

Zimmerman Seed Company:

Wamego, Kan., Feb. 13, 1911.

I ordered a few seeds from you last var, which proved very satisfactory.-J. W. Jennings, M. $U$. 


\section{Miscellaneous}

YELON PEACH-The fruit is the shape, size and color of an orange, while the flesh is pure white. They may be sliced and fried and also make delicious preserves, and are superior to peppers for use as mangoes. Pkt. 5c; postpaid.

GARDEN LEMoN-Smaller than the Melon Peach, but decidedly more acid, thus dispensing with the sliced lemon, so essential in putting up the melon peach. The fruit is striped dark green. Hkt. 5c: postpaid.

GROUND CHERI - Produces handsome fruit of yellow color: fine for canning, preserving, pies, etc. They are about $1 / 2$ inch in diameter and have a strawberry flavor. Excellent $w$ hen dried in sugar like raisins. Pkt. 5c: postpaid.

BIRSSELS SPROUTS-Resembles miniature cabbage. Very tender and of excellent flavor and hardy. Pkt. 5c; oz. $15 \mathrm{c}$; 1/4 lb. $503: 1 / 2$ lb. $90 \mathrm{c}$; postpaid.

BROCCOLI-Similar to Cauliflower. Will head in October or November. Pkt. $5 \mathrm{c} ; 0 z$. $25 \mathrm{c} ; 1 / 4$ lb. $90 \mathrm{c}$; postpaid.

CHICOR1-Used as a substitute for coffee. Pkt. 5c; oz. $10 \mathrm{c} ; 1 / 4$ 1b. 25c; $1 / 2$ 1b. $40 \mathrm{c}$ postpaid.

COLLARDS-The most satisfactory variety. Largely grown in the south for "Greens."

Pkt. 5c; oz. 10c; $1 / 4$ lb. $30 \mathrm{c}$; postpaid

Endive-The best variety. Preferred to lettuce by those who have tried it. Pkt. 5c; oz. 10c; $1 / 4$ lb. $35 \mathrm{c} ; 1 / 2$ lb. $60 \mathrm{c} ; 1 \mathrm{~b}$. $\$ 1.10$; postpaid.

GARLIC-Choice sets $35 \mathrm{c}$ per $1 \mathrm{~b} ; 3$ lbs. 903 ; postpaid. By express or freight, $25 \mathrm{c}$ per $1 \mathrm{~b}$

BORECOLE OR KALE-Divarf Green Curled-This is select stock; tender and of excellent flavor. Pkt. 5c; oz. 10c; postpaid. Siberian-Low spreading habit. Pkt. 5c; oz. $10 \mathrm{c}$; postpaid.

OKKA OR GUMBO-White Velvet-The finest variety. The pods can be split and stored for winter soups. Pkt. $5 \mathrm{c}$; oz. $10 \mathrm{c} ; 1 / 4 \mathrm{lb}$. $25 \mathrm{c} ; 1 \mathrm{~b}$. $75 \mathrm{c}$; postpaid.

RHUBARB-Victoria Giant-The standard variety. Pkt. 5c; oz. 12c; 1/4 1b. $40 \mathrm{c} ; 1 \mathrm{~b}$ $\$ 1.35$; postpaid.

LEEK-Large London-This is claimed to be more delicate than the onion for soup. Pkt. 5c; oz. 10c: $1 / 4$ lb. 30c; 1/2 lb. 50c; postpaid.

MUS'TARD-Giant Southern Curled-Flavor sweet and pungent. Large leaves, often measuring 12 to 14 inches. Pkt. 5c; oz. $8 \mathrm{c} ; 1 / 4$ lb. $20 \mathrm{c} ; 1 \mathrm{~b}$. $60 \mathrm{c}$; postpaid.

White Mustard-Leaves are light green, mild and tender. Pkt. 5c; oz. 8c; 1/4 ib. 15c; lb. $40 \mathrm{c} ;$ postpaid.

Erown Mustard-Stroner and more pungent than the white. Pkt. 5c; oz. 8c; 1/4 1b. 1 c): lb. $40 \mathrm{c}$; postpaid.

PEANUTS-White-Combines earliness, size and prolificness. Plkt. 5c; 1/4 oz. 12c; pt. -0c: qt. 35c; postpaid. By express or freight, peck $70 \mathrm{c}$; $1 \frac{1}{2}$ bu. $\$ 1.30$; bu. (22) $\$ 2.50$.

CRESS OR PEPPER GRASS-Early Curled-A well-known salad. Pkt. 5c; oz. $30 \mathrm{c} ; 1 / 4$

lb. $\$ 1.00$; postpaid.

Water Cress-To be planted around water. Pkt. 5c; postpaid.

GOURDS-We offer the following sorts: Dish-Cloth Gourd or Sponge Vine, Nest Egg, Dipper, Hercules Club, Sugar Trough and Mixed. Price of any, pkt. 5c; postpaid.

HERBS-Anise-Used for seasoning.

Borage-Leaves are used for flavoring; flowers good food for bees.

Catuip-Used for bee pasture, flavoring and teas.

Coriander-Seeds are used in manufactu $\cdot \mathrm{e}$ of confectionery.

Dill-The seeds have an aromatic odor and are used largely for pickling with cucumbers.

Horehound-Used as medicine for cough.

Hop Seed-rkt. $15 \mathrm{c}$ or 2 for $25 \mathrm{c}$.

Lavender-Used for perfume.

Safron-Used for coloring and flavoring certain dishes.

Sage-More used than any other herb for seasoning.

Summer Savory-Used for flavoring soups and dressings.

Winter Savory-Csed for flavoring soups.

Thym-Used for seasoning and medicinal qualities. packet.

Packets of any of the above 5c each; postpaid. Except Hop Seed, which is $15 \mathrm{c}$ per

\section{R. H . J A M E S \\ Grower of Vine Seeds}

Zimmerman Seed Co., Topeka, Kans.

Gentlemen:

You can put this seed out with the fullest confidence that it will give satisfaction. All grown from my own stocks and is pure. The Rocky Ford Cantaloupe is the Pollock rust-resistant, very similar to but better than Eden Gem or Netted Rock strains. Your seed is from the field I got the crate from which took first prize at the State Fair. Yours truly,

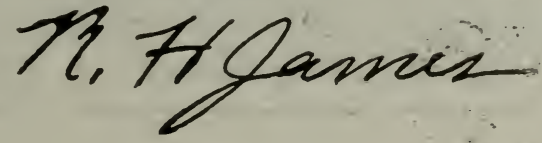




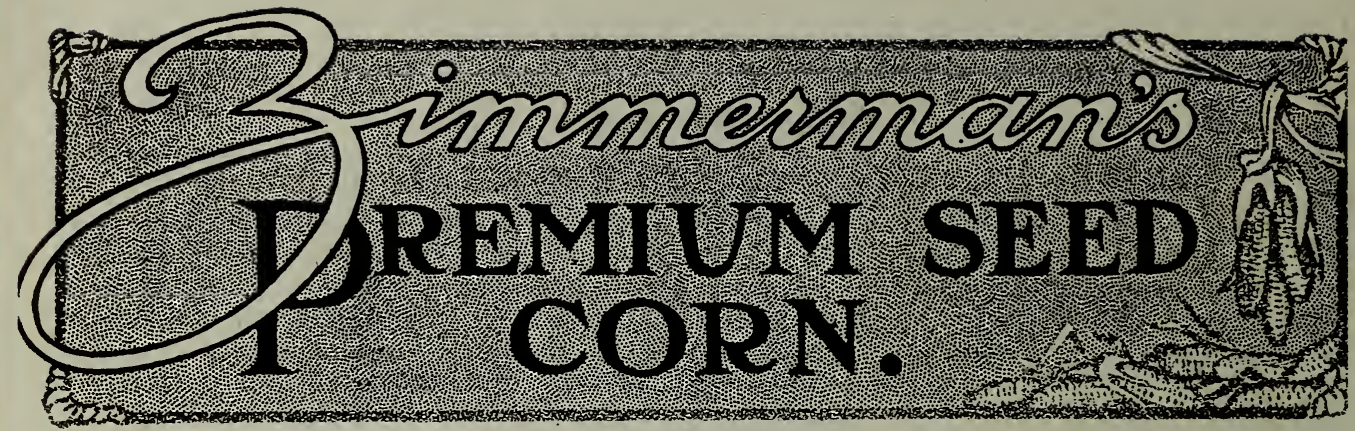

My Seed Corn is grown under special contracts and only the choicest ears are s6lected for seed. It is carefully sorted, hand picked, tipped, butted and graded. Every bushel is sold with the guarantee that if not as represented you may return it to me at once.

\section{The World's Purest and Finest Seed Corn!}

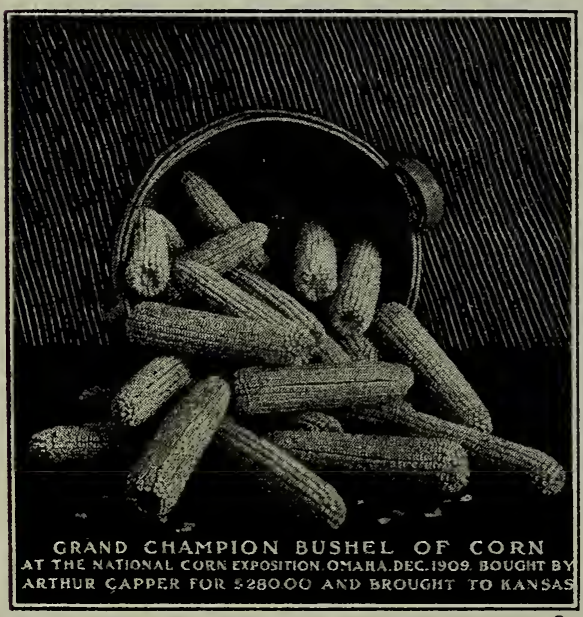

\section{"Grand Champion" WHITE}

Grown from this Grand Prize Bushel for which Arthur Capper Paid $\$ 280.00$

\section{Unequaled Opportunity for a few Quick Buyers}

\section{Here's the Proof!}

Topeka, Kan.

To Whom It May Concern: This is to certify that I purchased the Prize bushel of seed corn in the World's Contest at the National Corn Exposition, Omaha, Neb., December, 1909, for which I paid $\$ 280.00$. Some of the seed I gave to Mr. H. V. Cochran, a seed corn specialist of this, Shawnee, county.

(Signed)

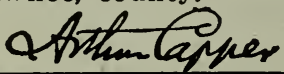

Topeka, Kan., Dec. 1, 1911.

To Whom It May Concern:

This is to certify that I secured from Mr. Arthur Capper, seed from the prize bushel of corn for which he paid $\$ 280.00$. I planted same and certify that the seed now being offered by the Zimmerman Seed Co., of Topeka, Kan., is from the original lot and that they have purchased my entire seed crop.

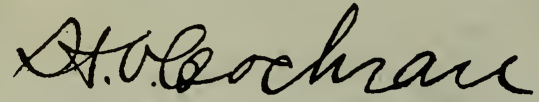

I have here a seed corn which is the purest and finest in the world. This is a strong statement, but the facts merit the statement. The original seed from which my "Grand Champion" seed was grown was shown in the world's contest at the National Corn Exposition, Omaha, Neb., was awarded the first prize and was purchased after the show by Mr. Arthur Capper, the Topeka publisher, for $\$ 280$.

My grower secured some of the seed from Mr. Capper and the seed I offer was grown from this stock, and you will find it the equal of the original bushel, which brought perhaps the highest price ever paid for a bushel of seed corn. It was grown for me by Mr. Cochran under a special contract.

The corn is a large pure white, deep grain; matures in less than 100 days and is an extra heavy yielder. If you want a seed corn of the finest possible type, do not fail to order some of this seed. Herewith you will find a statement from Mr. Capper, verifying the price paid for the seed. Also one from $\mathbf{M r}$. Cochran.

Price of this extra selected seed, tipped, butted and graded, is as follows: Pkt. 10c; pt. 25c; qt. 40c: postpaid. By express or frelght, peck $\$ 1.00 ; 1 / 2$ bu. $\$ 1.90 ; \mathrm{bu}$. \$3.75; two or more bushels at $\$ 3.50$ per bu. 


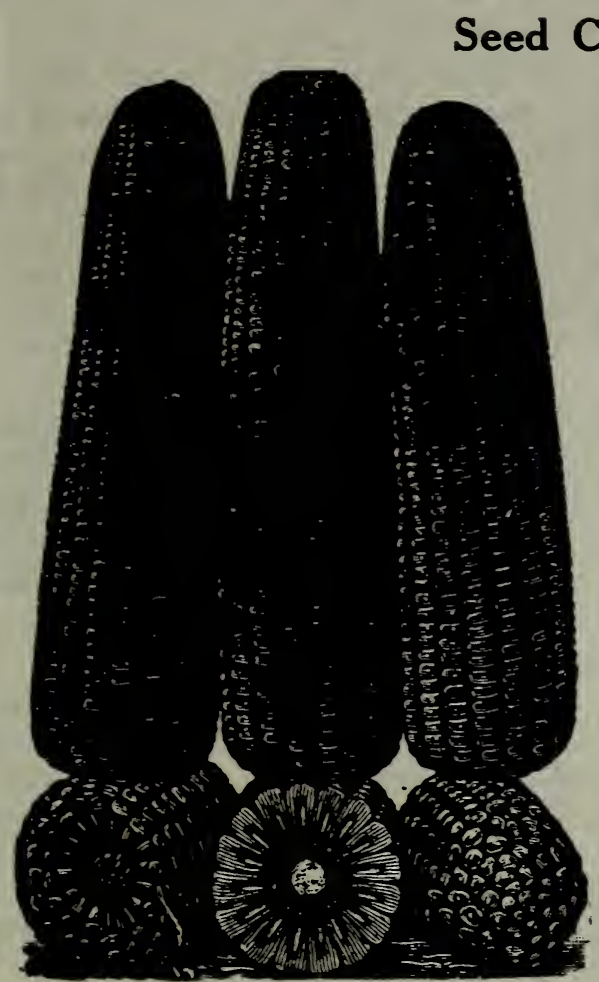

Zimmerman's 80-Day.

want. A load of this corn is always attractive and brings top prices on the market. Pkt. 5c; pt. 15c; qt. 25c; postpaid. By express or freight, selected, tipped, and graded, pk. 60c; $1 / 2$ bu. $\$ 1.05$; bu. $\$ 2.00$; four or more bushels at $\$ 1.80$ per bu.

Improved Reid's Yellow Dent-You will find my improved strain larger and heavier than the old ordinary, and it is equally as early, ears from 8 to 11 inches in length and filled with deep yellow grains, and it is a fine producer. Pkt. 5c; pt. 15c; qt. 25c; postpaid. By express or freight, selected, tipped and graded, pk. $60 \mathrm{c}$; $1 / 2$ bu. $\$ 1.05$; bu. $\$ 2.00 ; 4$ or more bushels at $\$ 1.80$ per bu.

Improved Leaming - This is one of the earliest yellow dent corns in cultivation, ripening in 90 to 100 days from planting. The ears are large and handsome, with deep, large grains; orange jellow color and red cob. Stalks produce two good ears each, which husk and shell very early. Pkt. 5c; pt. 15c; qt. 25c; postpaid. By express or freight, selected, tipped and greded, pk. 60c; 1/g bu. 81.05 ; bu. $\$ 2.00 ; 4$ or more buthels at $\$ 1.80$ por bu.
Zimmerman's 80-Day Corn-Early as the Pride of the North, but much larger eared and will yield with Reid's Yellow Dent, and other late varicties. I have been selling this corn the last few years all over the country and I have never received a single complaint. I planted this com myself and harvested corm fully matured in less than 8.j days. If rou want early teed you will find this corn most valuible. Ears run \& to 10 inches in length. kernels ô medium size, a rich yellow color and fill the cob to the very tip. It is not a big corn, but is perfectly reliable. Pkt. jc; pt. 15c; qt. 25̄c; postpaid. By express or freight. $1 / 2$ pk. 50c; pk. 90c; $1 / 2$ bu. $\$ 1.30$; bu. $\$ 2.50$. Four or more bu. at $\$ 2.25$ per bu.

Zimmerman's Perfected Golden Beauty-My Perfected Golden Beauty produces larger and heavier ears than the old Early strain. Ears that run from 10 to 14 inches in length and filled to the very tip with big, solid grains. My Perfected Golden Beauty is just what you

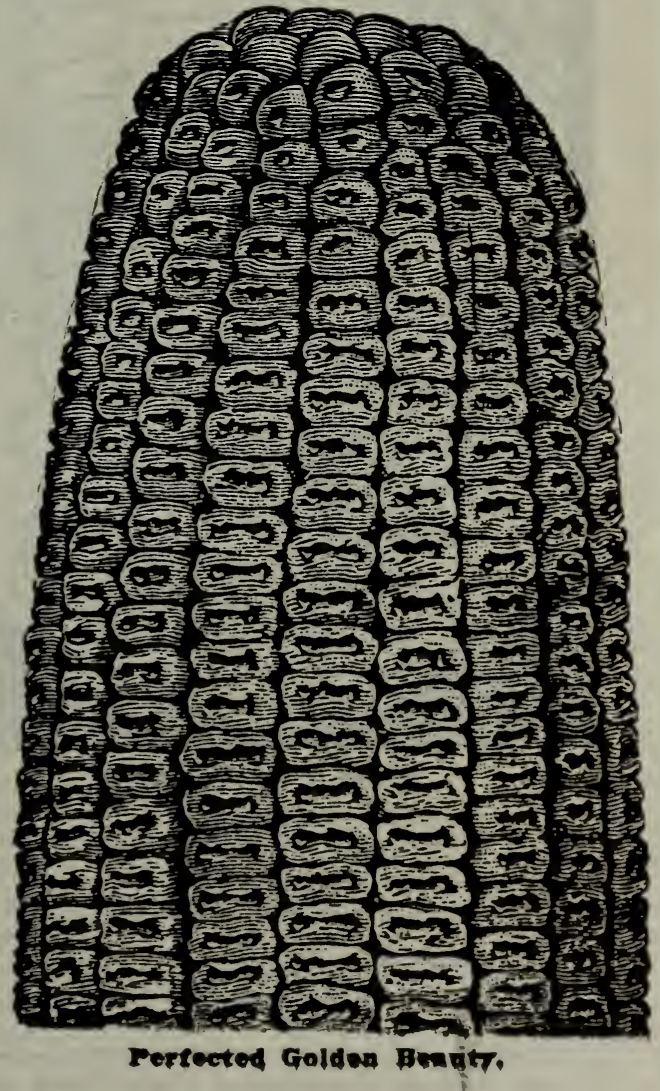




\section{Seed Corn-Continued}

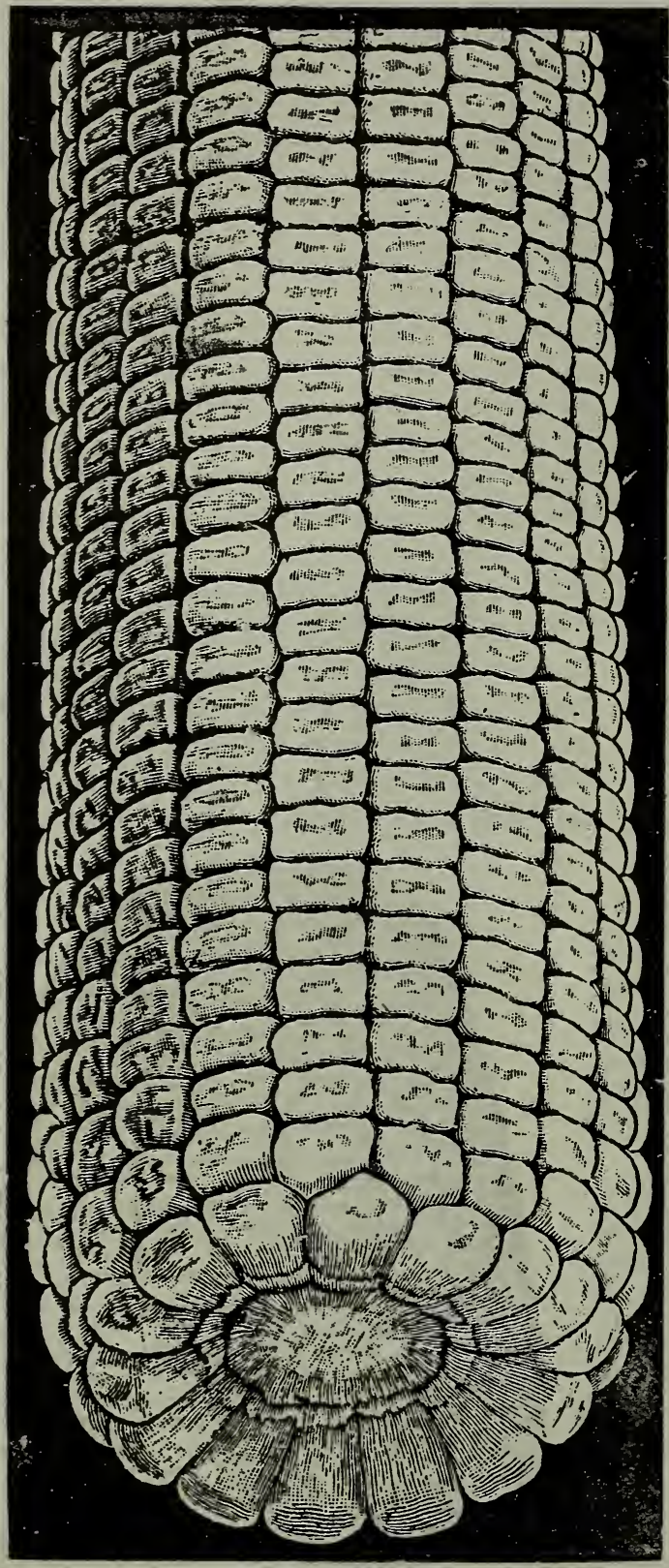

Hevne Coumts White.
Premium Strain Boone County White.

Boone County White-My strain of this favorite corn is furnished me by one of the very best seed corn growers in Kansas. This corn has never been defeated in a contest the last few year. It was awarded first prize at the Stat Fair of Topeka; first at Manhattan. Kan., in state contest; awarded diploma in National contest, Columbus, 0 . Other prizes too numerous to mention. The seed I offer is pure and sack after sack will show the same uniformity of kernels, the same color of grain. Boone County White is a well known standard variety which runs 12 to 18 inches in length. This corn is also grown for me by Mr. H. B. Cochran, the grower of the Johnson County IVlite, above mentioned. Pkt. 5c; pt. 15c; qt. 25c; postpaid. By express or freight, selected, tipped and graded, $1 / 2$ pk. 40c; pk. 60c; $1 / 2$ bu. $\$ 1.05$; bu. $\$ 2.00$; four or more bushels at $\$ 1.90$ per bu.

Silver Mine-One of the very earliest White Corns. It is a heavy yielder, producing ears of good size, containing 16 to 20 rows of derp, white grains. Pkt. 5c; pt. 15c; qt. 25c; postpaid. By express or freight, $1 / 2$ pk. $40 \mathrm{c}$; pk. $60 \mathrm{c} ; 1 / 2$ bu. $\$ 1.05$; bu. $\$ 2.00$. Four or more bus. $\$ 1.75$ per bu.

For Seed Potatoes, Field Seeds, etc., see Special Circular in this Catalogue.

Instead of putting the Field Seeds and Seed Potatoes in my catalogue as is the general custom, I have this year issued a special Field Seed circular, giving full description and latest prices. You will find this circular enclosed in this eatalogue. If for any reason you fail to find one, write at once and a copy will be mailed you.

Zimmerman Seed Company:

Haskell, Okla., Feb. 6, 1911.

I like your seeds and will order from you next year.-J. M. Edwards.

Kelly, Kan., March 1, 1911.

Zimmerman Seed Company:

You sent me good seed last year. Lots of people around here do not realize the difference between sood seed and the poor trash which you buy here. 

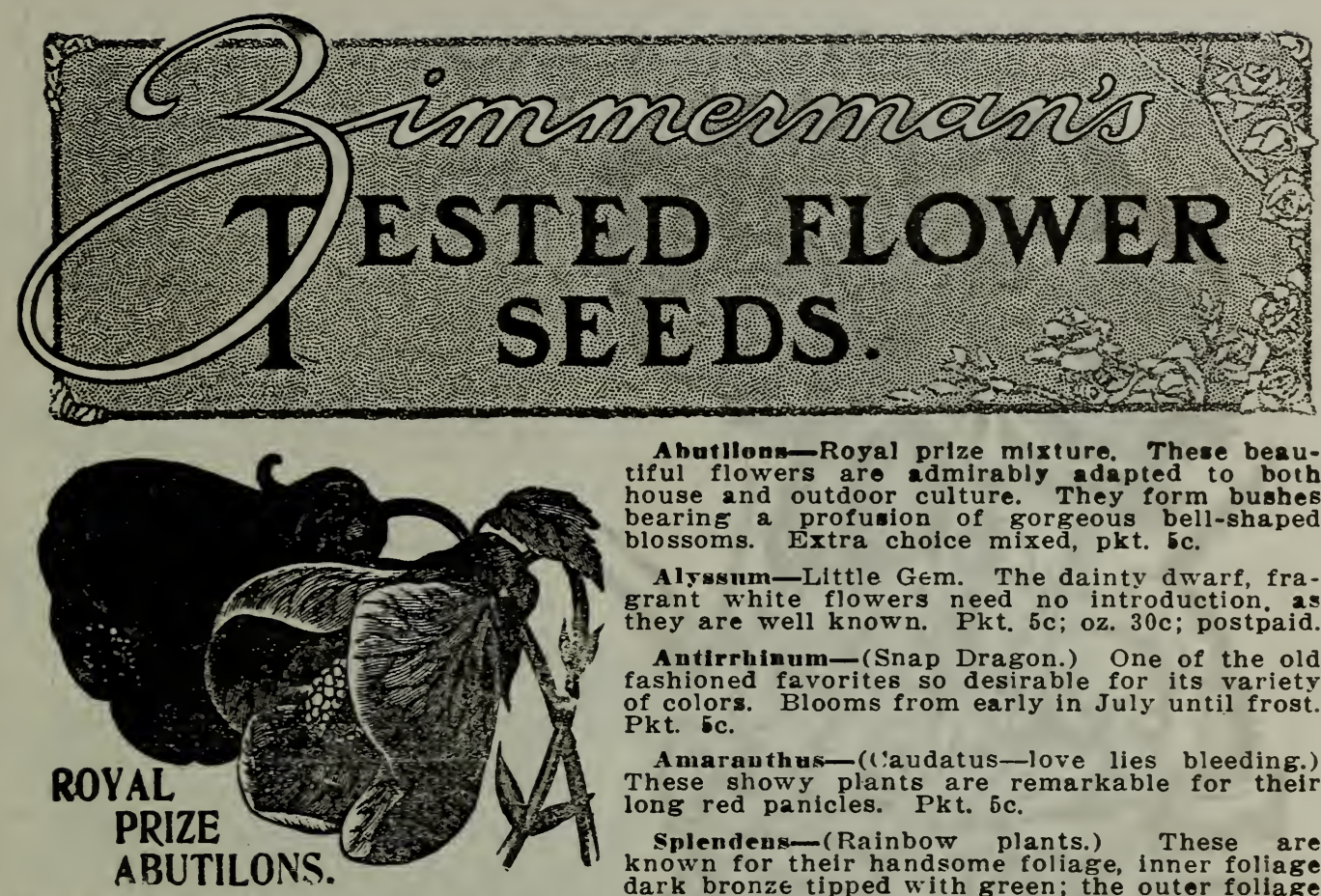

Abutlionn-Royal prize mixture. These beautiful flowers aro admirably adapted to botb house and outdoor culture. They form bushes bearing a profusion of gorgeous bell-shaped blossoms. Extra choice mixed, pkt. 5c.

Alyssum-Little $G \in m$. The dainty dwarf, fragrant white flowers need no introduction as they are well known. Pkt. 5c; oz. 30c; postpaid.

Antirrhinum-(Snap Dragon.) One of the old fashioned favorites so desirable for its variety of colors. Blooms from early in July until frost. Pkt. 5c.

Amarawthus-(laudatus-love lies bleeding.) These showy plants are remarkable for their long red panicles. Pkt. 5c.

Splendens-(Rainbow plants.) These are known for their handsome foliage, inner foliage dark bronze tipped with green; the outer foliage when exposed to light becomes gorgeous crimson and gold. Pkt. 5c.

Amarnithes Mired-Contains the above varieties and many more. Pkt. 5c.

Ageratum hardy annual. The flowers are bush-like, resembling an inverted tassel and are excellent for garden and winter blooming in the house. Pkt. 5c.

\section{Asters}

Timmerman' Early Beauty-I believe my Early Beauty is the most beautiful extra early Asters ever offered. It resembles a perfect Chrysanthemum with all the beauty of that flower. Its blossoms are borne on long stems, making it desirable for cutting. White, pkt. 10c; Pink, pkt. 10c; Mixed, pkt. 10c.

Pacony Flowered-Plants grow about 20 inches high and have long stems. Flowers are very double and shaped like a paeony. Mixed colors, pkt. $5 c$.

Lavender Gem-This is of the Ostrich-feathered type, the flowers being irregularly slashed and ringed, and are very double. Pkt. 15c; 2 for $25 \mathrm{c}$.

Rojal Purple-This is a handsome purple Aster. Pkt. 10c.

Dwarf Queen-Fxcellent for pot culture as well as for bedding. Mixed, pkt. 10c;

Branching-Grown from seed, have long stems

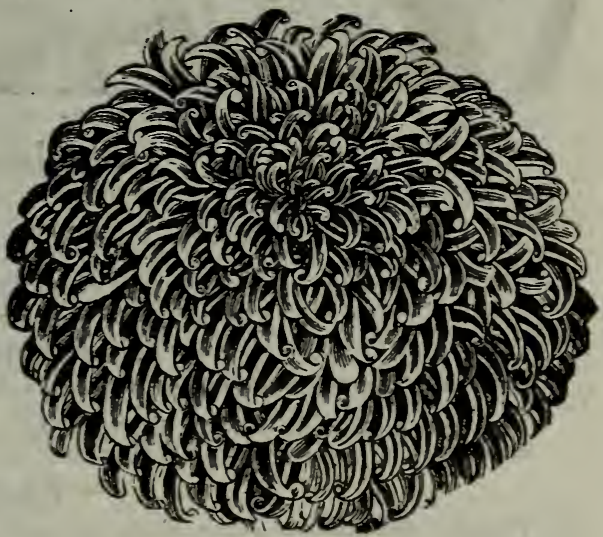

Early Beauty.

and are admirable for cutting. Pure White, pkt. 10c; Pink, pkt. $10 \mathrm{c}$

vietoria-One of the handsomest varieties of Asters. Flowers are large globular shape and very double. Mixed pkt. $5 \mathrm{c}$.

Comet-12 to 15 inches high, of branching habit. Carmine, pkt. 10c; Light Blue, pkt. 10c: Fine Mixed, pkt. $5 \mathrm{c}$.

Zlmmerman' Special Mixture-This contains the finest varieties and choicest colors. which are my own mixtures, and I feel sure if you wish an assortment of colors, this make a handsome bed. Pkt. 5c.

CETOISA

Dwarf leathered-Desirable for both bedding and pot culture. It reesmbles an ostrich plume. They greatly please lovers of the beautiful. Mixed, pkt. 5c.

Triumph of the Fxpomition-The beautiful bronze foliage and brilliant scarlet bloom of this plant are similar to that of Scarlet Sage. Desirable because of its early flowering and continuing to bloom until frost. Pkt. $5 \mathrm{c}$.

CHOICE BAISAM.

Camella Flowered Mixed-One of our specialties and we know we have as fine ceed as it is possible to procure. Flowers are double and very large. Pkt. 5c; White, pkt. 5c; Scerlet, pkt. $5 c$.

CINERARIA.

Hohrida Finest Mixed-nne of the choicext of plants for housa culture. In this mixture is every lovely celor to be had. Pkt. 10 . 


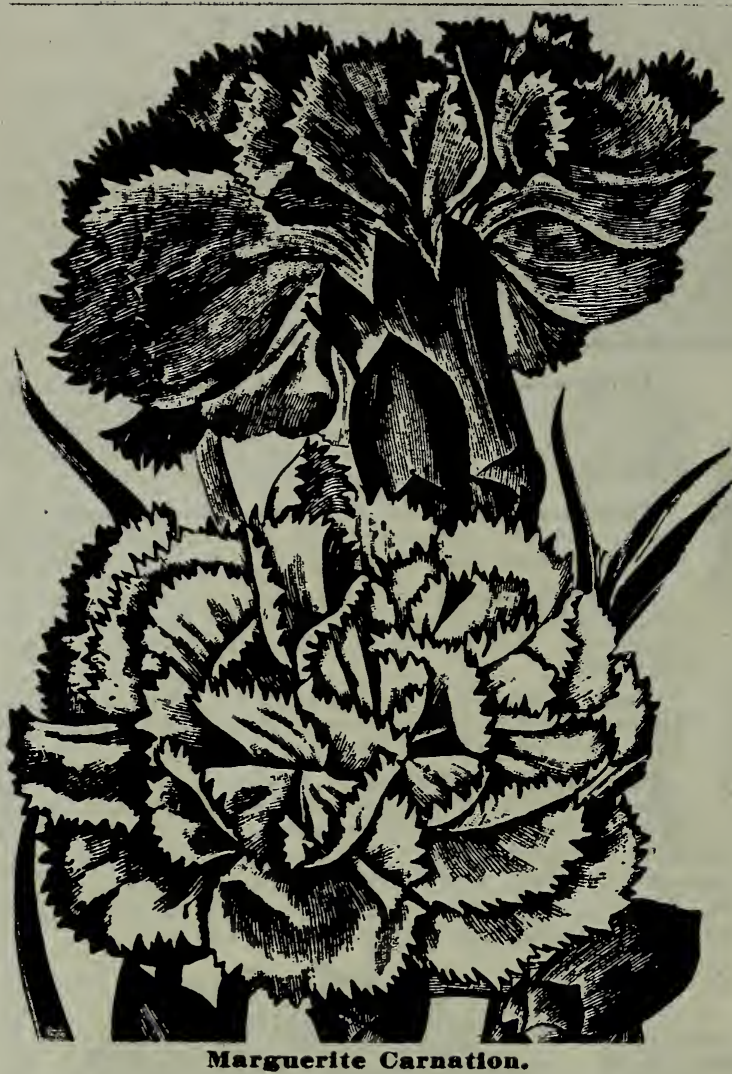

Dianthus (Marabillis)

\section{Coxcomb}

Queen of Dwarfs-Something new in Coxcomb. Bears large crimson combs, is very dwarf in habit, making it fine for borders and handsome for potting. Pkt. 5c.

Finest Mixed-Contains all the finest and best. Pkt. 5c.

\section{Canna Seed}

Giant Mixed-Has been saved from the choicest Cannas of our own growing and will produce a grand assortment of the finest varieties. Pkt. $5 \mathrm{c}$.

\section{Carnations}

Marguerite-Easily raised from seed. They flower in about four months from time of sowing. They are of vigorous, dwarf, erect growth, requiring no supports. Fine mixture of all colors. Pkt. 5c.

Giants of Callfornia-These are of dwarf, bushy habit. On account of its hardiness and abundance of brilliant and fragrant bloom it will be sure to please you. Pkt. 10c.

Bird of Paradise- This is truly a novelty, being one of the most interesting plants in cultivation. Produced in trusses and of yellow color, pistils of a rich red color spread out in fan shape. No description can do justice to this beautiful plant. Pkt. $5 \mathrm{c}$.

\section{Centaurea(Bachelor's Button)}

Double Mixed-The regular oldfashioned Bachelor Button. An old favorite. All colors. Pkt. 5c.

Cyanus-Sometimes called "Blue Bottle," "Korn Blume," etc. Mixed colors, pkt. 5c.

A new and unique type of Pinks. Flowers are feathery tinged, extra large and mixed colors. Pkt. $10 \mathrm{c}$.

\section{Coleus}

Leaves are broad and long, comprising all the shades of yellow, red, green, from the darkest to lightest. Fine mixed, pkt. $5 \mathrm{c}$.

\section{Dianthus (Chinese Pink)}

Pkt. 5c.

Dwart Fire Ball-Dwarf, compact in growth, petals fringed, deep red and very double.

The Bride-Pure white with deep purplish red center. Pkt. 5c.

Double Chinese Pinks-Giant Sweet William, excellent flowers. Pkt. 5c.

\section{Choice Dahlias}

Double Mixed-I offer Dahlia seed that if sown in early spring and then transplanted outdoors as soon as weather permits will produce an abundance of bloom by. fall." All kinds of double mixed. Pkt. $5 \mathrm{c}$.

Tom Thumb-These grow from 12 to 15 inches high and are covered with showy flowers. Mixed colors, pkt. bc.

\section{Comos}

I have the early flowering kind which produces bloom from July to November White or Pink, pkt. bc. Mixed, comprising every color, pkt. 5c.

\section{California Poppy (Escholtzia)}

My Special Mixture contains rare shapes, double and single. Pkt. 5c.

\section{Candytuft}

Hyaeinth Flowered-Flowers are immense size and resemble a Hyacinth. Pure white with long stems. Pkt. 10c.

Dwarf or Tom Thumb-May be sown at intervals of two or three weeks. Pkt. 5c.

White or Snowflake-Pkt. $5 c$.

Mixed Colorm-All colors. Pkt. $5 \mathrm{e}$.

\section{Chrysanthemum}

Yellow-A new color, very soft shade of lemon and perfectly double. Pkt. 5c; $1 / 2{ }^{*} 0 z .25 \mathrm{c}$ White These are double an of smow white color. Flowers through the summer and fall. Pkt. Be: 13 oz. $25 \mathrm{e}$.

Double Mised-Thi is a fine mixture of the very oholcest varietles. Pkt. 100; plets. abe. 


\section{HELIO TROPE.}

A hardy perennial, which is easily grown from seed.

Fine Mixed-Contains the choicest varieties. Pkt. $5 \mathrm{c}$

ICE PLANT.

Attractive on account of its peculiar green wavs foliage, whic his covered with t coating resembling crystals of ice. Pkt. Бc.

LARKSUR.

Emperor-A well-liked variety for its richness of color. Wach plant often bears flets or more erect spikes of flowers. Pkt. $5 \mathrm{c}$

HOLL YHOCK.

Giant Double Mixed-As fine and beautiful as the most double rose. Plants grox 4 to 6 feet high and produce flowers of every shade and color. Pkt. 5c.

FOR-GET-ME-NOT.

Alpestris-Blue and White. Pkt. $5 \mathrm{c}$.

Eliza Fon robert-Sky blue with yellow eve. Pkt. 5c.

Semperflorens-Blue and extra early. Pkt. 5c; Fine mixed, pkt. 5c.

Gollen-The foliage has a ferny appearance. making it good for bouquets. Pkt. 5c.

\section{Zimmerman's Nasturtiums}

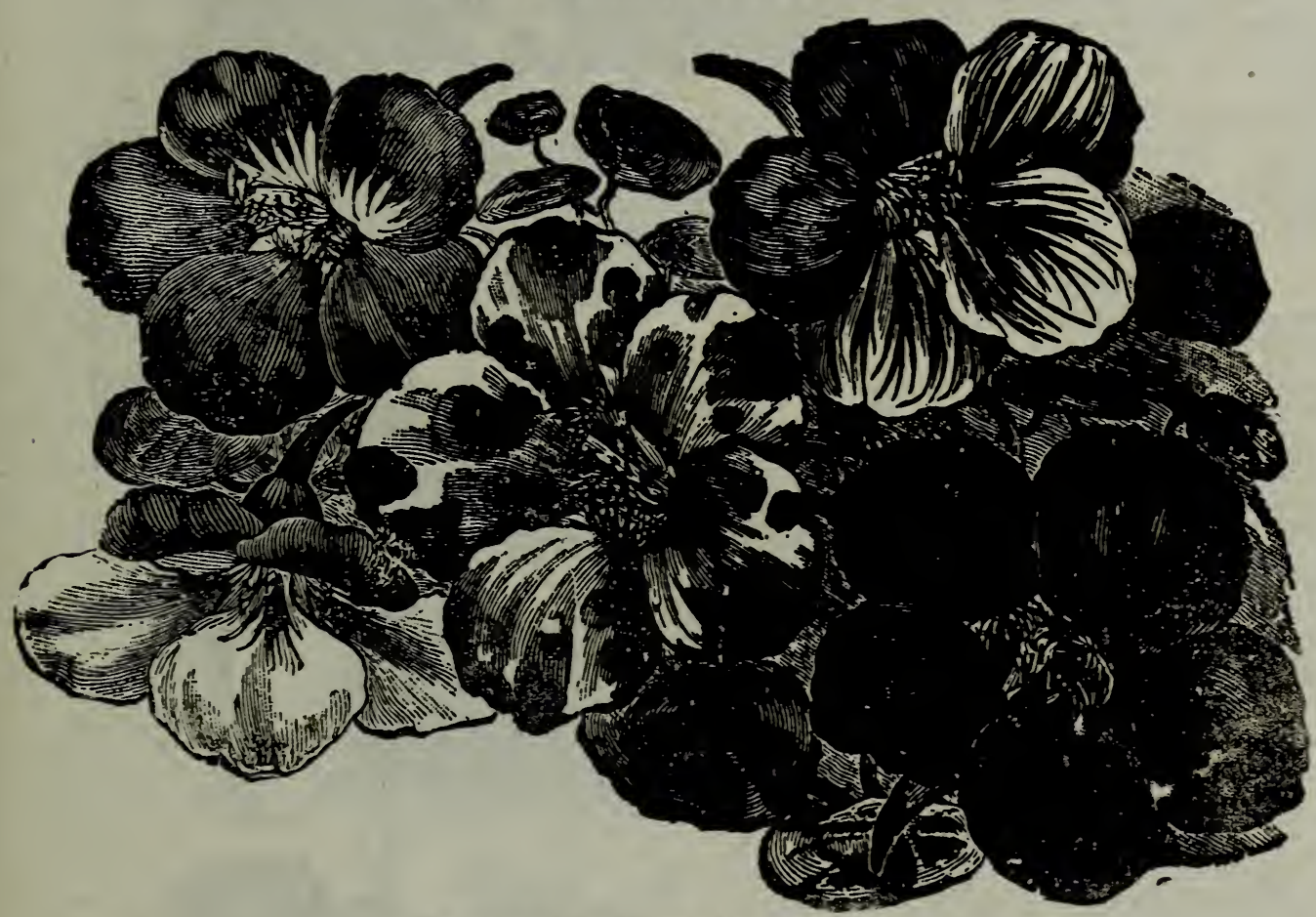

Zimmerman's Mixed Nasturtinms.

Hybrids of Madam Gunther-It is difficult to excel this in richness of color. The are climbers and continuous bloomers. There is scarcely a tint or shade that is not in this. Pkt. 5c; 0z. $10 \mathrm{c}$; $1 / 4$ lb. $35 \mathrm{c} ; 1 \mathrm{~b}$. $\$ 1.00$; postpaid.

Chameleon-i beautiful new variety and entirely distinct. On the same plant will be found self-colored flowers, others stained and blotched, others broadly edged and banded with light or dark shades. Pkt. 5c; 0z. 10c; $1 / 41 \mathrm{~b}$. 40c; postpaid.

King Theodore-A striking variety. A rich deep crimson with dark leaves. Pkt. 5c; oz. $10 \mathrm{c} ; 1 / 4$ lb. $35 \mathrm{c}$; postpaid.

Fire Fly-New and very attractive. the petals are beautifully marbled and striped. Pkt. $5 \mathrm{c}$; oz. $10 \mathrm{c} ; 1 / 4$ lb. $35 \mathrm{c}$; postpaid.

Dark Crimson-Deep velvety red or brownish red. Pkt. 5c; oz. 10c; 1/4 1b. 35c; postpaid.

Scarlet-Flaming red. Pkt. 5c; oz. 10c; 1/4 1b. 35c; postpaid.

ZIMMERMAN'S SELECT MIXTURE-This mixture will be found to contain all the choicest and finest varieties of Nasturtiums. It contains the rich, velvety Lobb, Madam Gunther, the new Chameleon. Firo Fly, in fact everything of especial merit. You will find it satisfactory in every way. Pkt. $5 \mathrm{c}$; oz. $10 \mathrm{c}$; $1 / 1 \mathrm{lb}, 35 \mathrm{c}$ : postpaid.

Trailing Nasturtiums-Lobb's Trailing. All cholce colors will be found in this; rapid growers. Pkt. 5c; oz. 10c; 1/4 lb. $35 \mathrm{c} ;$ postpa!d.

\section{DWARE N ISTURTIUIS.}

Select Dwarf Mixed-This is our specialiy prepared mixture of all the dwarfs. They are compact and bushy, foliage fo both dark and light type, colors very bright and pleas. ing. Pkt. 5c; oz. $10 \mathrm{c} ; 1 / 4$ lb. $35 \mathrm{c}$; 1b. $\$ 1.00$; postpaid.

Beauty-Gorgeous red and orange. Pkt. $5 \mathrm{c}$; oz. $10 \mathrm{c}$; $1 / \mathrm{ib}$. $35 \mathrm{c}$; postpald.

Pearl-Clear tint of lemon, fading to a primrose. Pkt. $10 \mathrm{c}$; $1 / 6$ 1b. 35c; postpald

Prince Henry-One of the most distinct and charming varieties, delicate tints of rose and straw color. Pkt. $3 \mathrm{c}$; oz. 10c; $1 / 4$ lb. 35c; postpaid.

Cloth of Gold-Compact growth with bright golden yellow leaves and brilliant scarlet flowers. Fkt. $5 \mathrm{c}$ : $n \%, 12 \mathrm{c} ; \mathrm{1} / \mathrm{ib}$, $4 \mathrm{c}$ : pmatpaid. 


\section{Single Mixed-Best single variety. Pkt. 5c. Double Mixed-Fine double flowers. Pkt. 25c. \\ The free flowering quality of these make them especially suitable for rockeries, pots, edging flower beds, etc. Pkt. $5 \mathrm{c}$. \\ GA ILLARDIA.}

Gaillardia-Mixed sizes and colors, very double, borne on long stems. Makes it excellent for cutting. Pkt. 5c. MIGNONETE.

New Golden Machet-Prized for its fragrance and earliness. It is a delicate shade of lemon, foliage dark green. Pkt. 5c.

Improved Sweet MachetPkt. $5 \mathrm{c}$.

Migmonette Mixed-This is the best mixture. Pkt. $5 \mathrm{c}$.

Mixed-Bloom the first year and are very showy. Flowers measure 8 inches in length. Fkt. כ̄ c.

\section{PANSIES}

Zimmerman's Giant German Mixture.-We scarcely know how to describe this grand mixture because we calunot do it justice. It contains the richest reds, all the distinct colors of Trimardeaus, the great Masterpiece with its delicate veinings and ruffled petals. It is the grandest mixture obtainable and we have spared no expense to make it so. Plit. $10 \mathrm{c} ;$ oz. $24 \mathrm{c} ; 1 / 2$ oz. $\$ 1.00 ; \mathrm{oz}$. $\$ 1.90$; postpaid.

Pausy Mixture-This is a special mixture of the best known varieties Each strain is exceptionally fine for tedding. Pkt. 5c; oz. 12c; $1 / 2$ oz. 60c: oz. \$1.00; postpaid

Californin vixture-California seed is what is generally sold by seedmen, cornuosed of fine varieties, but not so rich or large as my impurted German seed. Pkt. 5c; $1 / 2$ oz. $40 \mathrm{c}$; oz. $75 \mathrm{c}$; postpaid

Masterpiece- $-\mathrm{N}$ e $w \quad G$ i a $n t$ Curled. Nearer to double Giant Pansies than anything ever introduced under that name In reality the number of petals is the sarne as that in other pansy flowers. but they are crimped and curled so that they look double. The flowers are large, uften 3 inches across and the colors are very odd and striking. Pkt. 10c; 3 for $25 \mathrm{c}$; $3 \dot{2}$ oz. $\$ 1.00$; oz. $\$ 1.90$; postpaid.

Snow Queen-Very fine. A pure Satiny White. Plit. 5c.

lellow-Distinct variety. Pkt. 5c.

Purple Mantle-A deep rich purple. Pkt. 5 c.

lied Rillng Hoon-Several shacies. of flaming-red. Plit. 5c.

Vicloria Ked-Pretty shade of crimson. Pkt.5c.

I'urple-Deepest shade of purple known.

Pkt. 5c.

King of the $=$ Hlacks-Flowers almost coal black, very velvety. The black is considered one of the finest by the most oritical. Pkt. 5c.

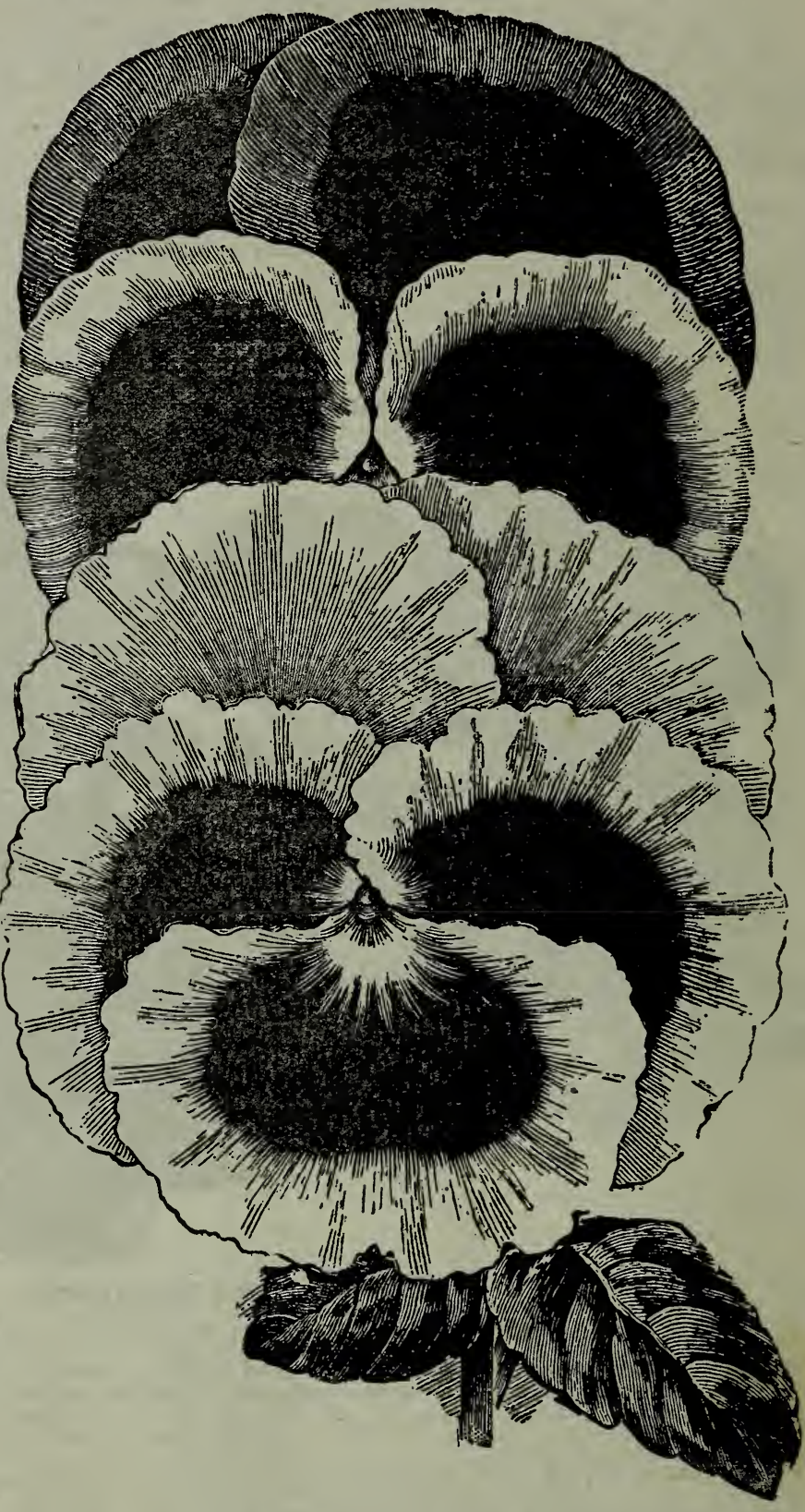

Zimmerman's Giant Pansies.

Silver Edge-Dark purple, silver border. Pkt. 5c.

Priuce Bismarck-Beautiful shades of brown and golden-bronze, marbled. Pkt. 5c.

Pheasant's Eye-Upper petal sky-blue with violet edge, lower ones mottled and variegated.. Pkt. 5c.

Faust-Deep fetty black. Pkt. Sc.

Sweet Scented-This is tho result of crossing. the Pansy with the Sweet Violet Very fragrant, large and have great di. versity of color: possess the hardiness of violets. Pkt. 100: 3 for $2.6 \mathrm{c}$ 
IA R VEL OF PERU. (Four O'Clock.)

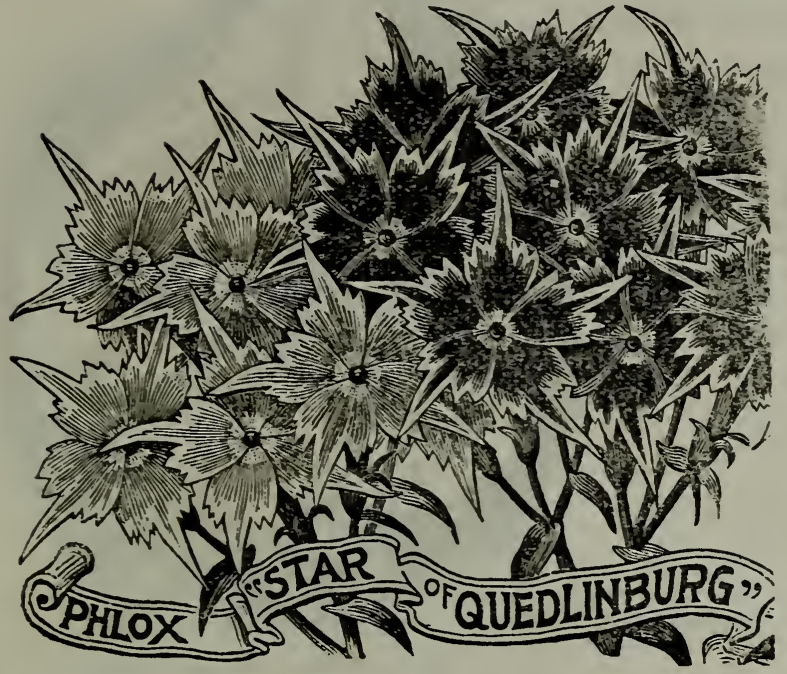

PHLOX.

Star of Quedlinburg-A very beautiful and attractive strain of Pholox. Blossoms are curious pointed and slashed. Pkt. $5 \mathrm{c}$.

Splendens-Pretty red flowers with white eyes. Pkt. 5c.

Alba Grandiflora-These are magnificent pure white flowers. Pkt. 5c.

Fine Mixed-This is a fine mixture of all the prettiest colors and the finest varieties. Pkt. 5c.

\section{PETUNIAS.}

For easy culture, freedom of bloom, fragrance and variety of colors it is hard to surpass the Petunia. I offer the choicest large flowering variety.

Hybrida Striped-Each plant forms a complete bush 5 to 10 inches in height. Flowers are blotched and striped. Pkt. $5 \mathrm{c}$.

Choice Mired-A select mixture containing a great assortment of colors. Pkt. 5c.

Zimmerman's Giant Double Mixed-This mixture is composed entirely of the very finest of Double Petunias. If you would have the very finest and largest flowering Double Petunias, you have it here. Pkt. 20c; two for $35 \mathrm{c}$.

RICINUS (Castor Oil Beans)-Plants grow 14 to $20 \mathrm{ft}$. high. Large scalloped leaves. thickly set from top to bottom of bamboolike stems makes them useful for shading purposes: at the same time they are very ornamental. Pkt. $5 \mathrm{c}$.

Sensitive Plante-Touch the foliage and it immediately. wilts, but soon revives. Bears pretty pink flowers. Pkt. 5c.

SALVIA. (Scarlet Saze.)

Splendens-A most gorgeous plant. For months the great spikes of flaming scarlct alriost cover the foliage. Pkt. 5c.

\section{KENILWORTH IVY.}

Easy growing from seed and one of the most beautiful basket or vase plants. It is a hardy perennial and likes shade and mois, ture. Pkt. 5c.

\section{PRIMULA. (Chinese Primiose.)}

Fine Mixed-This contains a mixture of all varieties and colors. Will give a succession of flowers throughout the season. Pkt. $5 \mathrm{c}$.

\section{SMILAX.}

One of the most desirable window vines over grown. Its graceful foliage of rich glossy green has a most desirable effect. plet. $5 \mathrm{c}$

Frair Dalbz a beautiful limht lavender. rufned a nd nuted. Plit. Oc: oz. 10e:
Every conceivable color in this mixture. Pkt. 5c.

PORTULACA. (Moss.)

Double IRose Filowered-?rsem bles a miniatuie rose: nuthing prettier. Pkt. $5 \mathrm{c}$.

Sinale llica-Preferred by many to the double. Pkt. $5 \mathrm{c}$.

\section{KOCHIA TRICOPHYLLA.}

An ornamental plant growing rapidly from seed. In the fall the plants are covered with scarlet flowers. Very attractive. Pkt. 5c.

\section{MARIGOLD.}

Lemon Queen-Large and very double, an inch in diameter and cover the plants profusely. Pkt. 5c

African Double Nixed-All varieties mixed. Pkt. $5 \mathrm{c}$.

\section{IIMULUS. (Minkey Flover.)}

Tigrinus-Excellent for baskets and vases. It is famous for its rich and beautifully blotched and singularly shaped flowers and tender foliage. Pkt. $5 \mathrm{c}$.

\section{SELEC'T POPPIES.}

Suowdrift-One of the most beautiful of Poppies; pure white flowers, perfectly double. Pkt. 5c.

Shirley-My strain of Shirley Popples contains new and beautiful forms, colors in single, $s \in m i-d o u b l e$ and double. rkt. $5 \mathrm{c}$.

Golden Gate-These have fine blooms in a combinatoin of colors. Pkt. 5c.

Iixed-Containing all the popular varieties and species of Poppies; a mixture which grows beautifully and attractive. Pkt. 5c.

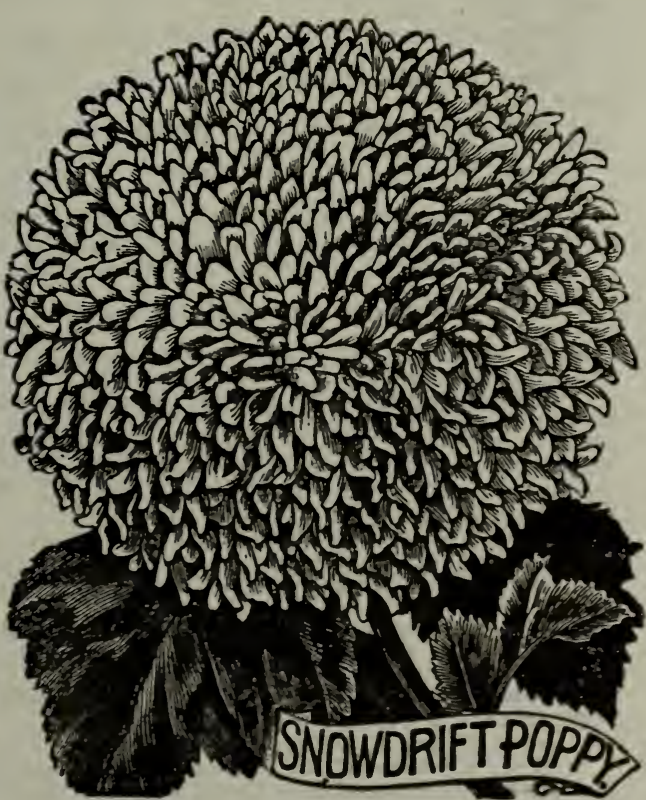


VERBENAS.

Italinu Striped-Large showy striped flowers of many colors. Pkt. 5c.

Mammoth Mixed-Composed of the rery finest large verbenas, of bright colors. Pkt. $5 \mathrm{c}$.

ZINNIAS.

Mammoth Mixed-Mixture of the largest Zinnias. Very double and show rare shades not found in most collections. Flowers are striped and marked in scarlet, gold and white. Pkt. bc.

Pompone Mixed-Cone-shaped flowers, ranging from pink to scarlet, and from pure white to cream and buff. Pkt. $5 \mathrm{c}$.

Double Lilliput Mixed-Forms bushes 15 inches high and covered with tiny double flowers about the size of a dalsy. Pkt. 5c.

\section{SUNFLOWER.}

Many Flowernig Double-These grow very tall and perfectly double, and one flower at $\epsilon$ ery leaf. Produce great quantity of seed, which is good for chickens. Plkt. 5c.

Minature-Very dwarf and bushy, with small leaves; flowers are very minute and pretty. Plants resemble the Dahlia. Pkt. sc.

\section{sTOCKS.}

Globe Pyramidal-Has immense stocks of double flowers, measuring from 2 to 3 inches in diameter. Mixed, pkt. $5 \mathrm{c}$.

Ten Weeks-The old favorite 10-week stocks. Pkt. 5c.

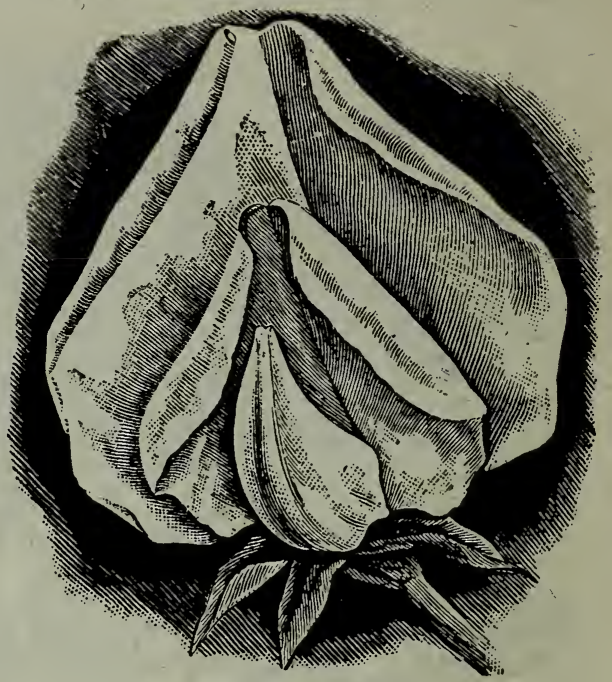

Snow White Sweet Peas.

SWEET WILIIAM.

Choice Mixed-This contains double and single, ali colors mixed. Pkt. 5c.

\section{Select Sweet Peas}

\section{ZIMMERMAN'S SELECT MIXTURE.}

This contains the very finest varieties and mixed according to my directions.' 'Pkt. $5 \mathrm{c} ;$ oz. $10 \mathrm{c} ; 1 / 4$ lb. $20 \mathrm{c}$; lb. $50 \mathrm{c}$; postpaid.

Snow white-This is a most beautiful Sweet Pea. It is early. of extra large size, while it is pure snow white, which makes it one of the most beautiful of Sweet Peas. Each stem has 3 to 4 blossoms open at the same time. Pkt. 5c; oz. 10c; 1/4 1b. 25c; ih. 60c; postpaid.

Prices of any of the following varieties, pkt. 5c; oz. $10 \mathrm{c} ; 1 / 4$ lb. 20c; 1b. 50c; postpaid: Mont Blane-Very early and of pure white color.

Blanche Burpee-Very large and pure white.

Queen Vietoria-Light primrose, shaded with purple.

Sunbeams-Light primrose and red.

Dainty-Large white with pink edge.

Sensation-A beautiful buff and pink.

Katherine Tracy-A soft, rosy pink,

with light edge.

Venus-Salmon-buff with rose pink shading.

Prima Donna-Large size and a bright pure pink.

Apple Blossom-Heavy shade of pink and rose on silvery-white.

Royal Rose-Deep crimson at center, with soft pink wings.

King Edward VII-Extra large size; deep crimson shading lighter at the wings.

Searlet Gem-Flower's are almost a daz-

zling scarlet.

Prince Edward of York-Scarlet on salmon.

Miss Wilmott-Standard is orange-pink, shading to rose.

ZIMMERMAN'S SUPERB MIXED SPENCERS-My mixture of the "Spencer" type of Sweet Peas is composed entirely of the very finest named varieties and mixed in my own seed-room and $I$ know it is the very finest assortment posible to secure. Contains some of all the varieties named below. This assortment with its large, crumpled and wavy flowers comprises all colors. and hues. Pkt. 5c; $1 / 2$ oz. 12c; oz. 20c; 1/4 1b. $35 \mathrm{c} ; 1 \mathrm{~b}$. 90c; postpaid.

Nora Unwin-A giant white, finely waved and fluted; the finest White Spencer. Pkt. 5c; oz. $10 \mathrm{c} ; 1 / 4$ 1b. $25 \mathrm{c}$.

Burpee's White spencer-A grand and beautiful pure white variety. Pkt. 5c;oz. 10c;

1/6 1b. $25 \mathrm{c}$.

Primrone Spencer-A pure yellow. Pkt. 5c; oz. 12c; 1/4 lb. 30c.

Primrome Spencer-A pure yellow. Pkt. 5c; oz. 12c; $1 / 4$ 1b. $30 \mathrm{c}$. Pkt. $5 \mathrm{c} ;$ oz. $10 \mathrm{c} ; 1 / 4$ 1b. $25 \mathrm{c}$.

True Countess Spencer-In size, form and coloring they are most beautiful, of a dark rose pink. Pkt. 5c; oz. $10 \mathrm{c}$; $1 / 4$ lb. $25 \mathrm{c}$

John Ingram $-A$ beautiful shade of rose. Pkt. $5 \mathrm{c} ; 0 \mathrm{z} .10 \mathrm{c} ; 1 / 4 \mathrm{~b} .25 \mathrm{c}$.

E. J. Castle-Rich carmine with salmon shading. Pkt. 5c; oz. 10c; 1/4 1b. $25 \mathrm{c}$.

Queen Alexandra-Glant scarlet flowers. Pkt. Ee; oz. $10 \mathrm{c} ; 1 / \mathrm{t} 1 \mathrm{~b}$. 25c.

Holen Lewi-Artistically ruffled: very large flowers of crimson and orange. Pkt. $5 c ; 0 \% 10 \mathrm{c} ; 1 / 4$ 1b. 250. 


\section{Select Bulbs-(Fine Named Cannas)}

The following comprises a list of the best Cannas. Price dormant roots, 16c each; 3 for $40 \mathrm{c}$; 12 for $\$ 1.50$; postpaid.

Allemannea-Orange red with gola bor-

der dotted with red. 4 to $6 \mathrm{ft}$. high.

Betsy Ross-Rose ping: $3 \mathrm{ft}$.

David Harum-Bright Scarlet, dark follage: $3 \frac{1}{2} \mathrm{ft}$.

Dr. Nansen-Deep yellow

Fiorence Vaughan-Yelow, crimson spots; 3 to $4 \mathrm{ft}$.

Gladiator-Tail variety, yellow with crimson dots.

Loufaiana-Brilliant scarlet; 6 to $7 \mathrm{ft}$. $3 \mathrm{ft}$.

adelphia-One of the bGet crimson:

Queen of Holland-Deep rich orange; 8 to $4 \mathrm{ft}$.

The Express-Immense cluster, tine bedaler; 8 ft.

Mixed Cannas $10 \mathrm{c}$ each; 3 for $25 \mathrm{c} ; 12$ for $\$ 1.00$; postpaid.

\section{DAHLIA BULBS.}

We have the finest line of Dalhia Bulbs obtainable and prices are very low.

California-Large double yellow free bloomers.

Nymphea-Shell pink with blush center

Croquette-Dark red.

Ifriem Hildi-A Cactus Dahlia, beautiful shell pink, petals are twisted and extra long flowers.

May Lomas-Large white, shading to rosy lavender.

Prices of any of the above $15 \mathrm{c}$ each; 6 for $75 \mathrm{c}$ : $\$ 1.25$ per doz: postpaids.

Jamaca-Large dark purple.

Twentieth Century - White with yellow center.

Blue obon-Almost a solid biue.

Progress-Fancy decorated soft rose striped crimson.

Livoni-Very double and soft bluish

The following two varieties are extra fine $15 \mathrm{c}$ each; 6 for $80 \mathrm{c}$; 12 for $\$ 1.50$; postpaid.

Queen Enmer-Combination of colors and the finest of the Paeony flowored class, pink with gold markings of inner petals.

Silviu-Soft pink with white center, extra large.

Mixed Dahlias- $10 \mathrm{c}$ each; 6 for $50 \mathrm{c} ; 1$ doz. for $90 \mathrm{c}$; postpaid.

\section{BEGONIAS.}

Tuberous Rooted-These are fine for pot culture or bedding. Low compact growth, waxy green leaves form a beautiful background for flowers which range from ivory white and scarlet through tints of rose, crimson, orange and bronze yellow.

Single Mixed-Good, strong tubers, each 10c;3 for $25 \mathrm{c} ; 12$ for $80 \mathrm{c}$; postpaid.

Double Mixed-Each 12c; 12 for \$1.00; postpaid.

Gladiolus Mixed-All colors, by mall postpaid, 10c; 12 for 50c; postpald. By express. $\$ 3.00$ per hundred.

DAHLIAS.

Large variety, consisting of all colors. We can furnish.

PAEONIES.

Once planted will last a lifetime. Pink or Crimson, 25c each; 6 for $\$ 1.25$. Pure White, $30 \mathrm{c}$ each; 6 for $\$ 1.50$; postpaid.

OXALIS,

White, pink and red colors or mixed; prices, 4 for $5 \mathrm{c} ; 12$ for 10c; 25 for $15 \mathrm{c}$; 50 lor $40 \mathrm{c}$; postpaid.

\section{CALADIUM.}

Elephant Eurs-Most effective for single plant on the lawn or massed in large beds. Has light green leaves, often $3 \mathrm{ft}$. by 20 inches. $12 \mathrm{c}$ each; 3 for $30 \mathrm{c}$; postpald.

\section{TUBEROSE.}

Excelsior Pearl-We handle nothing but the highest type of tuberose. Flowers are pure waxy white and very sweet scented. $5 \mathrm{c}$ each; 3 for $10 \mathrm{c} ; 12$ for $40 \mathrm{c}$; postpaid.

\section{GLOXIANIA.}

These are beautiful bevond description. Flowers quickly after planting. Why not stait some for Easter Decoration? Mixed, $12 \mathrm{c}$ each; 3 for $30 \mathrm{c}$; 12 for $\$ 1.00$; postpaid.

\section{Climbers}

Japanese Moruing Glories Mixed-They are of gigantic size, from 4 to 6 inches across and contain every color, and blending of colors, in the rainbow. Are striped, blotehed. mottled often having from 10 to 12 colors in a single flower. Pkt. 5c; postpaid.

Cypress Vine- Has the finest dark green follage of any op the garden vines. It wlll grow on trunks of old trees and fences and trellis. Pkt. 5c; postpald.

Canary Bird-Delicate vine, with handsome follage and bears an abundance of canary-colored flowers. Pkt. $5 \mathrm{c}$

Wistaria-Called Hyacinth Bean, etc. One of the prottlest climbers: covered with heautiful flowers. Pkt. 5c.

Cobae Vine-Very rapid annual climber, running up 20 to $30 \mathrm{ft}$. in season. Bell. shaped flowers of purplish lilac color. Pkt. 5c.

Zimmerman Seed Company:

Centralia, Kan., March 87, 1911.

I will certainly speak a sood word for your seed, as wo have used it and know it is O. K. -W. R. Murphy.

Zimmerman Seed Company:

Lost Apringe, Kan., Feb. 28, 1911.

Recived my order; everything correct. Thunk yeH for your prompt attentlon.- Pery truly yours, Mrs, Claud Waylan. 


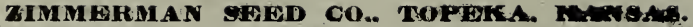

\section{Roses and Plants}

Orders for Roses and Plants will be filled separately from seed or other orders and will be shipped as soon as the weather will permit. When an entire collection is not desired, selection of any of the varieties offered may be made at $15 \mathrm{c}$ each. postpaid.

\section{SUNFLOWER COLLECTION.}

Six Hardy Everblooming Roses for 60c; postpaid.

Etolle De Lyon-A beautiful pure yeliow tea rose, bearing flowers early and late. Stands both heat and cold. One of the best for general use.

Etoile De France-A grand, new velvety crimson rose, hardy and everblooming. It is fine for cut flowers. Taken all in all, it's one of the best of its class.

Gruss Au Teplitz-Splendid new everblooming. This is the reddest of all red roses and one of the best for the amateur, who has no green house and depends on the garden for flowers; it succeds under most ordinary cultivation and conditions. The foliage is beautiful.

Kaiserin Augusta Victoria-One of the finest white roses, combines all the good qualities.

Killarney-Flowers are rich rosy pink of large size; the buds are long and pointed.

Wellesley-A Hybrid Tea, and free bloomer.

Price 45 c postpaid.

THE LA FRANCE SET.

La France Set-The old garden favorite, the queen of all Rosts. No variety surpasses its silvery rose coloring.

Duchess of Albany-This Rose is much like La France, except its color is more brilliant, it being a very gorgeous red.

Champion of the World-A lovely clear deep pink. Flowers large size.

Princess Ronnie-A richer crimson was never seen in a Rose, while its fragrance is even more delicate than the La France.

\section{HAPPY HOME COLLECTION.}

16 handsome hardy roses for $\$ 2.00$, postpaid -6 red, 6 pink, 1 striped and 3 white. This assortment comprises none but the most desirable varieties and will give pleasure to all purchasers.

Alfred Colcomb-Crimson: Anne De Delsbach, shell pink; Caprice, striped, pink and white; Coquette Des Alps, Blush White; Coquette Des Blanches, cream; Francois Levet, cherry red; Gen. Jacqueminot, scarlet; John Hopper, rose pink; Mad Gabriel Luizet, coral; Mad Plantier, white; Magna Charta, pink; Mrs. Jno. Laing, pink; Oakmont. deep pink; Paul Neyron, pink; Ulrich Brunner, cherry red; Prince Camille De Rohan, maroon.

\section{THE THKEE SOUPERT ROSES.}

\section{2c; Postpaid.}

Hardy and continuous bloomer. If you want roses that will give you absolute satisfaction from the day they are planted, we would urge that you plant these famous varleties. Of dwarf, stocky, uniform growth.

Clothilde Soupert-Color a French white, deepening to a rosy-blush in the center. Its greatest value lies in its compact, vigorous habit and wonderful profusion of bloom, even the smallest plants being literally covered with flowers.

Iellow soupert-The same as the foregoing, except color which is white on a beautiful light yellow.

Pink Soupert-Same as Yellow Soupert except color which is a fine rose pink, but variable. several shades being borne at the same time.

\section{VEILCHENBLA U OR RIIIE ROSE.}

$15 \mathrm{c}$ each; postpaid.

(Violet-blue seedling from Crimson Rambler.)

After years of effort rosarians have been rewarded by the production of a blue rose, which will be welcomed with the greatest interest by all lovers of the garden. This new climbing rose surpasses all others of recent introduction in having a pure blue color. The flowers appear in large clusters, after the manner of the Crimson Rambler, and semi-double ard of medium size. Upon first opening, the color is partly bright red and partly bright rose, turning soon to a steel blue. The color is best described by saying that it resembles the color of early violets. This variety is a strong grower, has shining green foliage and few thorns. Be the first in your neighborhood to show this grand rew novelty.

"FLOWER OF FAIRFIELD," THE EVERBLOOMING CRIMSON FAMBLER.

For many years past it has been the f.ndeavor of every rose grower to produce a climbing variety that would be of perpetual flowering habit. The many beautiful varieties of Rambler Roses were valuable acquisitions, but none of them could be called perpetual or everblooming, they producing on?y one crop of flowers during the season. It is a sport from the famous Crinson Rambler; it is of the same color if not a shade more brilliant, and has better resisting power to the sun. Flower of Fairfield blooms very profusely on young wood the first year after planting. It is very effective for covering walls, trellises or arches, and is equally attractive for table decoration or other use as cut flowers.

BA BY IRAMBLER-The everblooming I'warf Crimson Rambler, in bloom continuously. This rose begins to bloom when very small. forming clusters of flowers as large as the Crimson Rambler. It is a brilliant red, of bushy habit, compact growth, forming plants $11 / 2 \mathrm{ft}$. high in a 6 -inch pot. This rose bids fair to be the most popular for bedding, for it wili bloom all suminer.

The following varieties are valued for training over arbors, trellises and verandas,

etc. Price 12c each; 3 for 30c; postpaid.

Criman Hambler-This is a splendid rose, and another year's trial proves that it is perfectly hardy, making shoots 10 to $12 \mathrm{ft}$. in a season. Produces 25 to 30 flowers in clus. ter, entirely covering the plant from the ground to the top with a mass of bright, glow.

ins crimson. It has been very largely advertised and is very popular.

The White Rambler-Pure white, small double flowers. It is a fiting companion tor 
the Pink Rambler, closely resembling it in foliage as well as in the great cluster of pure white flowers.

Dorothy Perkins-A grand new sort remarkably like Crimson Rambler. but the flowers are more double and of a beautiful shell pink color. Very hardy.

\section{AMERICAN BEA UTY.}

$16 \mathrm{c}$ each; postpaid.

Color deep pink and crimson, handsome flowers. These are the most beautiful and popular roses grown.

HARDY FLOWERING SHRUBS.

Shrub orders must reach us not later than April 18th. We cannot fill orders for shrubs after that time.

Althea (Rose of Sharon)-Covered with rose-like flowers durnig August and September, when other flowers are scarce. We have three colors-red, purple and white, all double. Each 12c; 2 for 20 c; postpaid.

Snow Bull (Ordinary)-Price $12 \mathrm{c}$ each; 2 for $20 \mathrm{c}$; postpaid.

Snow Ball (Japanese) - Very choice. both in foliage and white blossoms. Difficult to propagate, hence its higher price Price, $15 \mathrm{c} ; 3$ for $40 \mathrm{c}$; postpaid.

Hydrangea Panticulata Grandiflora. (The Hardy Hydrangea.)-Every branch is crowned with an immense panicle of fleecy white flowers, changing to a pink hue from August to October. $10 \mathrm{c}$ each; postpaid.

Hydraugea Oraska-Japanese valiety; produces immense heads of pink flowers. A little shade and plenty of water meets all their demands. Set away in the cellar to rest in the winter. Price, $16 \mathrm{c}$ each; postpaid.

Hydrangea Thos. Hoge-Large white. May be grown for lawn or pot plant on the veranda: Price, $15 \mathrm{c}$ each; postpaid. One each of Thos. Hogg and Otaska for 30c; postpaid.

Spirea (Meadow Sweet)-This class of shrub will amply repay one with an abundance of flowers: easy cultivation, rapid growth, etc.

Spirea Vau Inuttel-A plant that sends up many tall shoots, which curve carefully toward the ground loaded with white bloom in May or June.

Spirea Bumalla-A d d arf variety, rose colored flowers, bears all summer. Price, 12c each; 5 or more at $10 \mathrm{c}$ each; postpaid.

\section{HARDY PERENTIAL PHLOX.}

$15 \mathrm{c}$ each: 6 for $80 \mathrm{c}$; 12 for $\$ 1.50$; postpald.

Aug. Riviere, bright red; Cocinea, scarlec; Coquette, white with crimson eye; Cross of Honor. White with band of rose in center of each petal, forming a Maltese cross; Eclair, reddish carmine with dark eye: Edgar Quinet, rosy amarinth: Isabey, orange salmon with crimson center; Lothair, soft, redish pink, rose eye: Madain Benzansom, deep crimson: Pantheon, salmon rose, free flowering; The Queen, pure white.

Rubeckia (Golden Glow) Doulle These are one of the handsomest ormamental plants for the garden, lawn or park. Easy to grow: sure to bloom; great vellow flowers as fine as cultiavted Chrysanthemums. Price, $10 \mathrm{c}$ each; 3 for $25 \mathrm{c}$; postpaid.

\section{COLEUS PLANTS.}

Coleus or Folinge Plant-We offer a variety of Coleus, the most desirable for bedding. 12c each: pustpain.

Gulden Bellier-Deep yellow variety.

Fire firnul-I lark crimson. shaded garnet.

Johu Good-Light green, spotted yellow.

SIIASTA DAISY.

The new giant Daisy is one of the best of Mr. Luther Burbank's productions, bearing only a slight restmblance to the common dalsy. The new Shasta Daisies often measure 4 to 5 inches across and are borne on stems 2 to 3 feet long. They succeed anywhere and in hot or cold locations blooming throughout the season in great profusion. Price. $12 c$ each; 3 for 30 c; postpald.

\section{IIIRDY IIERBACEOUS PLANTS.}

To this class of plants belong those that are hardy. Once planted they live forever.

Japnuese Irix-The truly lovely Iris is among the most desirable summer flowering plants: many flowers measure from 10 to 12 inches in diameter. Price, $12 \mathrm{c}$ each; $6 \mathrm{for}$ 60c; postpaid

lily of the Valley-These dainty flowers should be in a moist, shadv location. Once planted the crowns increase each year, soon making a large bed. which blooms every year. Strong crowns, 6 cents each: 12 for 50 c: postpaid.

BleellinL Menrt-One of the fine old favorites of Grandmother's garden. Produces rose colored heart-shaned flowers in abundance in April and May. Strong roots. Each, $15 \mathrm{c} ; 3$ for $40 \mathrm{c}$ : postpaid.

Cimbrella punt-This plant is as handsome as a fern or palm for decoration. It will grow in water and is useful for aquariums and fountains. Each, 14c; 3 for $30 \mathrm{c}$; postpaid.

\section{HA IRDY CLIMBEIRS.}

rlemntis-These ornamental, hardy vines for house fronts, or may be used with fint effect on fences, etc. We list the best varietles: Duchess of Fdinburgh, double white; Henryi, pure white: Jackmanni, flowers large, rich, velvety, produced in masses; Madam Baron Veillard. quite like its parent, Jackmanni, but colnr bright lavender; Madam Edouard Andre. nearest to red in the Clematis family: Paniculata, small flowers borne on long stems, in clusters, in August: Ramona, large lavender, blue flowers, often 9 inches across.

Price. 14c each: 3 for $30 \mathrm{c}$ : postpaid. 1 each of the seven varieties for $60 \mathrm{c}$,

Cinnimon Vine-Very rapir climber, and will grow for years. Strong tubers. 10c each; 3 for $20 \mathrm{c}$; 12 for $50 \mathrm{c}$; postuaid.

\section{HON EYSUCIKI,ES.}

Humh-Red and white Tartarian, 12c each or 2 for 20c; postpaid

Chineme-Reddish green foliage, red flower. buds when expanded show cream petals. Hnil' Jnנnn-Pure white flowers changing to yellow. Bloom from July to November. Monthly Fragrant-All the name implies: red and yellow blossoms.

Scarlet Triumph-Red trumpet-shaped flowers.

Price. 12c each; one of each variety for $40 c$; postpald.

English Ivy-Hardy; follage dark green and glossy. Good for covering walls and 
Bround where grass will not grow. Price, 12c each; 3 for 30c; postpaid.

Wisteria - Valuable where tall growing vines are desired. Flowers are long and in clusters.

CARNATIONS.

$15 \mathrm{c}$ each; 3 for $40 \mathrm{c}$.

Beacon-A splendid red variety. Large and gracefully formed.

Enchantress-Exquisite delicate shade of silvery pink.

Harlowarden-A bright dazzling crimson, large and best of its color.

James Whitcomb Riley-A pure yellow carnation.

May Day - Exquisite shade of satiny pink.

White Enchantress-Absolutely pure white in color.

winsor-A clear silvery pink.

Price, 12c each; three for $30 \mathrm{c}$; postpaid.

Black Hawk-Dark crimson-scarlet, looks like velvet. purple.

Dr. Enguehard-Japanese incurved. Color, a true pink, without the least trace of

Golden Glow-A bright yellow of velvety finish.

Glory of the Pacific-Pink color and of magnificent size.

Intensity - Flowers of massive size, deep, rich, velvety crimson color.

Jeannie Nonin-Large size, perfectly globular, finely finished, pure white.

Major Bonaffon-Color soft, clear yellow.

\section{FERNS.}

Boston Sword Fern-One of the most popular sorts. Splendid for pots, vases or hanging baskets, especially desirable grown in wire hanging baskets in which they thrive well and make very ornamental plants. $15 \mathrm{c}$ each; postpaid.

Asparagus Sprengerli-It is a fine plant for hanging baskets, with graceful arooping fronds sometimes 4 feet in length. The color of the foliage is a rich shade of green and will retain its freshness for weeks after being cut. $15 \mathrm{c}$ each; postpaid.

Asparagus Plumosus Nanus-This variety is often called the Shaking Fern. Its $\mathrm{fine}$ bright green, feathery foliage.surpasses the Maiden Hair Fern in a delicacy of texture. The sprays, after being cut off, will last for a long time and are indispensable as a green, in floral decorations. 150 each; postpaid.

ostrich Plume Fern-Combines graceful pluminess and charm with additional features of good shape and size. Price, 15c each.

\section{POULTRY SUPPLIES}

Special Catalogue of Incubators, Brooders and P oultry Supplies Sent Free.

PURITY BABY CHICK FEED.

My Baby Chick Food is composed of pure grain and seed, cleaned in a mill built expressly for that purpose. It is then run through two sets of screens, taking out all dust and dirt, leaving only the pure nutritious muscle material cut the proper size for baby chicks. This food complies with the Pure Food Laws, and is Registered and Analysed by the State of Kansas. More chicks die when 3 to 10 days old than at any other time. Clean grain and muscle material is what they want, and this food supplies the want and the price is low. $25 \mathrm{lbs}$. at $75 \mathrm{c} ; 50 \mathrm{c}$ lbs. $\$ 1.40 ; 100$ lbs. $\$ 2.50$. If you do not find it as represented you may return it to us at once.

\section{SPECIAL UNPARALLELED OFFER}

Combination Seed Drill, Plow and Cultivator Given Away Absolutely Free.

There is a great demand for garden cultivators and drills, but most small gardeners cannot afford to deners cannot afford to duce our seeds and get you to send us a neighborhood order we will send this complete drill, plow and cultivator, absolutely free, with an order for garden and flower seeds, amounting to $\$ 10.00$ and over. It is a practical tool, strong. durable and simple. It does not clog and will drop any quantity of seed desired.

Your boy will keep your grarden clean by "playing farming." Why not get up a neighborhood order and secure one of these drills? Your boy could get up an order for $\$ 10.00$ in the neighborhood with a few hours' work, and he will then have this special garden outfit.

The average price of Garden Drill, Cultivator, etc., run from $\$ 6.00$ to $\$ 10.00$ for the machine alone. We are giving it away free with a $\$ 10.00$ order for vegetable and 1 lower seed. Field Seed is not ineluded in this offer.

Read what some of the people who have one say about it. well pleased with it.
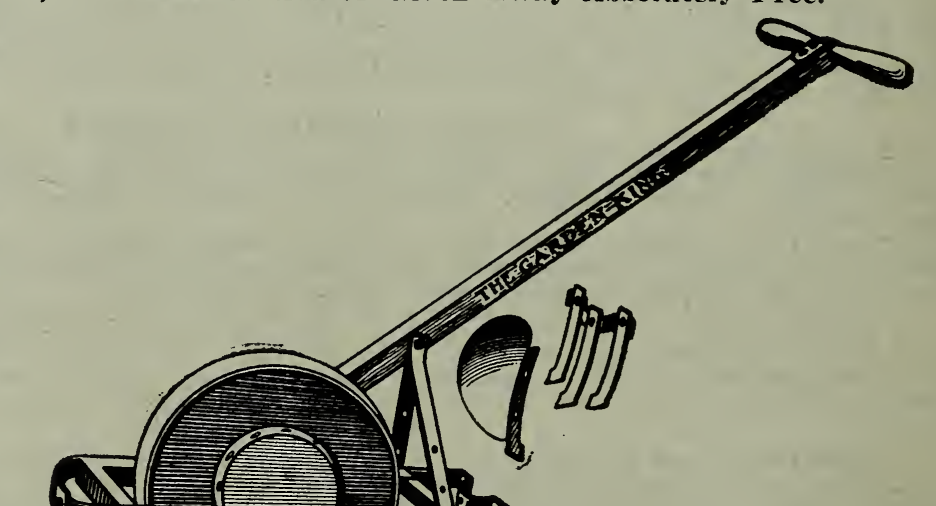

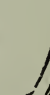

t.

Mr. J. D. Zackory, Magnolia, Ark.: Am well pleased with the Drill.

Mrs. Iillze Mulchi, Norden, Nebr.: I llke the Seed Drill very much. 


\section{WHOLESALE PRICE LIST FOR MARKET GARDENERS}

No order for less than $\$ 5.00$ will be accepted at these prices. Shipments at these prices by express or freight not prepaid. $1 / 2$ lb. at pound rate, $1 / 2$ pk. at peck rate, $1 / 2$ bu. at bushel rate. Cash in full must accompany all orders. I hope to receive your order and will give it prompt and careful attention.

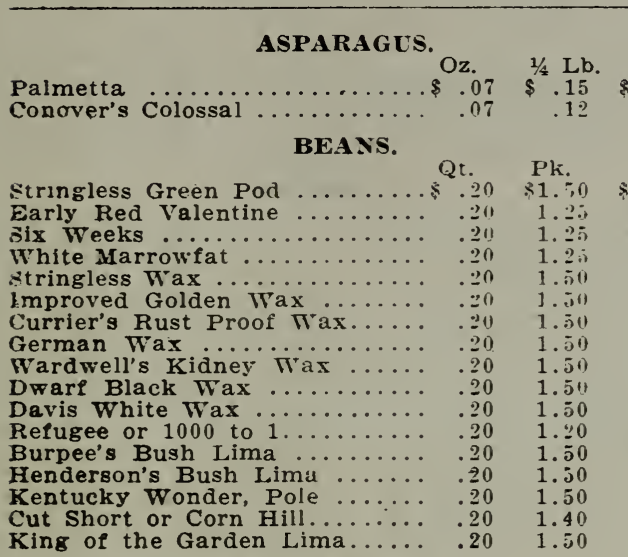

GARDEN BEETS.

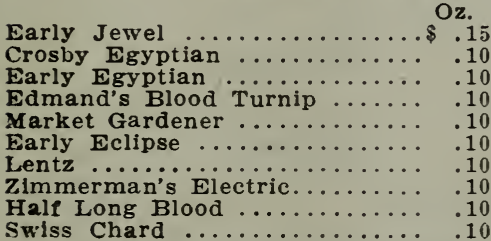

BEETS FOR STOCK.

Golden Tankard ........... \$ .05 Improved Mammoth Prize ...... .05 Long Red $\ldots \ldots \ldots \ldots \ldots \ldots \ldots, .05$

Lane's Imperial Sugar .......... .05

Improved Wanzleben Sugar .... .05 BROCCOLI.

Large White .............. .20 \$ .75

BORECOLE OR KALE.

Dwart Green Curled .........\$ .08 \$.15

CABBAGE.

First to Head ............. .20

All Head Early $\ldots \ldots \ldots \ldots \ldots \ldots \ldots$ \% .15

Early Jersey Wakefield $\ldots \ldots \ldots$.....

Early Winningstadt...........

Zimmerman's Earliest ......... .15

Extra Early Etampes ......... .15

Early Summer ..............

Early Flat Dutch $\ldots \ldots \ldots \ldots \ldots \ldots \ldots \ldots \ldots \ldots$

St. Louis Market from st. L.... .20

Zimmerman's Sure Head ..... . 15

Giant Flat Dutch ...............

Short Stem Drumhead ........ .12

Danish Ball Head $\ldots \ldots \ldots \ldots \ldots$.......

Mammoth Red Rock ......... .18

Savoy Drumhead ...........

\section{CAULIFLOWER.}

\begin{tabular}{llrrr} 
& \multicolumn{3}{c}{ Pkt. } & $1 / 4$ \\
Early Snow & Oz. & $1 / 4$ L.b. \\
Dwarf Erfurt $\ldots \ldots \ldots \ldots$ & .12 & $\$ .55$ & $\$ 2.00$ & $\$ 7.50$ \\
Early Paris Forcing $\ldots \ldots$ & .15 & .60 & 2.25 & 8.50 \\
& .05 & .20 & .60 & 2.00
\end{tabular}

\section{CARROTS.}

Ox-Heart or Guerrande $\ldots \ldots \ldots \ldots$

Danvers Haif Long..............

Improved Long Orange .......... .08

Large White Belgian $\ldots \ldots \ldots \ldots$
Large Yellow Belgian.. $.6 \ldots$

\section{CELERY.}

Golden Self Blanching (French) \& .25 White Plume $\ldots \ldots \ldots \ldots \ldots \ldots \ldots . .15$ Giant Pascal ......................
$1 / 4$ Lb. Lb.

$\begin{array}{rr}.35 & 1.25 \\ .30 & 1.00\end{array}$

$\begin{array}{rr}.30 & 1.00 \\ .30 & 1.00\end{array}$

$.30 \quad 1.00$

.301 .00

.30
35
1.00

1.25
1.00

1.25

\& .15

.15
.15
.15

.15

$\$ .75 \quad \$ 2.50$

$.35 \quad 1.25$

.35
.35 1.25

$.40 \quad 1.45$

$.35 \quad 1.15$

$.35 \quad 1.25$

วิ 2.00

1.20

1.10

1.10

1.30
1.30

1.50

1.50

2.00

1/4 Lb. Lb.

$.25 \quad .75$

.25

.20
.20

.20

$\$ .85$

.40
.30
.35

.35

.60

.60

.60

$\$ 3.00$

1.30

1.25
Large Rooted

CHICORY

COLLARIS.

Georgia or Southern ........ $.0 \$ \$ .20 \$ .70$

SWEET CORN.

Extra Early Adams.. \$ $\$^{1 / 2} \mathbf{P t}$. Pt. Qt. $\$$ Q $\$$ Pk. Bu.

Peep-O-Day

$10.15 \quad .20 \quad 1.00 \quad 3.75$

Zimmerman's E a 1 . 1 :

Molden Bantam

Early Minnesota

Perry's Hybrid

Mammoth Cory

Crosby's Early

Country Gentleman

Stowell's Evergreen

Late Mammoth

Black Mexican

Sugar Drip ....

$\begin{array}{ll}.10 & .15 \\ .10 & .15 \\ .08 & .10 \\ .08 & .10 \\ .08 & .10 \\ .08 & .10 \\ .10 & .15 \\ .08 & .10 \\ .08 & .10 \\ .10 & .15 \\ .10 & .15\end{array}$

$\begin{array}{rrr}.20 & 1.00 & 3.75 \\ .20 & .90 & 3.50 \\ .15 & .90 & 3.50 \\ .15 & .90 & 3.50 \\ .15 & .90 & 3.50 \\ .15 & .90 & 3.50 \\ .20 & 1.10 & 4.00 \\ .15 & .90 & 3.25 \\ .15 & .90 & 3.25 \\ .20 & 1.00 & 3.75 \\ .25 & 1.25 & 4.50\end{array}$

POPCORx.

White Pearl.

Lb. 25 L.bs.

Queen's Golden

White Rice .........

New Early Marvel

CUCUMBER.

Zimmerman's Earliest $\ldots \ldots \ldots \ldots \$$. 15

Early Perfection

Arlington White spine

Early Cluster ................ 10

Chicago Pickling

Boston Pickling

White Wonder

New Everbearing

Improved Long Green ....... 10

Davis Perfect

Cool and Crisp ................ 10

Japanese Climbing.

West India Gherkin

EGG PLANT.

Black Beauty . .

$\begin{array}{cccr}1 / 2 & \text { Oz. } \\ 3 & \text { Oz. } & 1 / 2 . L b \\ \$ .20 & .40 & \$ 1.25 \\ . & .15 & 30 & 1.00\end{array}$

Improved Purple

ENDIVE.

Green Curled

Bulbs

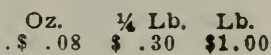

\section{GARLIC.}

KOHL-RABI.

White

........

\section{LEEK.}

Large London

LETTUCE.

New Early Head ........... . $10 \$ .35 \$ 1.20$

Zimmerman's Earliest

New Early Crisp

Early Curled Simpson

Black Seeded Simpson

Grand Rapids

Crisp as Ice

Improved Hanson

California Cream Butter ....... .08

Early Prize Head $\cdots \cdots \cdots \cdots \cdots, .08$

Denver Market ......................

White $\ldots \ldots \ldots \ldots \ldots \ldots \ldots$.

iUstaRd.

Southern Curled $\ldots \ldots \ldots \ldots \ldots \ldots \ldots, \quad 05$

$\$ .08 \$ .20$

MUSHROOM SPAWN.
$\$ .40 \$ 1.40$

1.40

$\$ 1.00$

$\begin{array}{rr}.35 & \$ 1.20 \\ .20 & .70 \\ .20 & .70 \\ .20 & .60 \\ .20 & .60 \\ .20 & .60 \\ .25 & .75 \\ .20 & .60 \\ .20 & .60 \\ .20 & .60 \\ .20 & .60 \\ .20 & .60 \\ .20 & .60 \\ .20 & .60\end{array}$

$\begin{array}{lr}.10 & .25 \\ .10 & .25 \\ .15 & .45\end{array}$

Lb. 5 Lbs. 
MOSX METONS.

Zimmerman's Best $\ldots \ldots \ldots \ldots \ldots$ Ox. Zimmerman's EarllestLarge .... .10

Paul Rose ................. .10

Norfolk Button ............. .10

Extra Early Hackensack ...... 10

Rocky Ford .............. 10

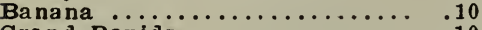

Gránd Rapids

Zlmmerman's Excelsior ....... .10

Emerald Gem ............... 10

Osage $\ldots \ldots \ldots \ldots \ldots \ldots \ldots \ldots . .10$

Montreal Market ............. 10

Burrell's Gem .............. .10

Tip Top $\ldots \ldots \ldots \ldots \ldots \ldots \ldots \ldots \ldots \ldots \ldots \ldots$
Success $\ldots \ldots \ldots \ldots \ldots \ldots$

WATERMELONS.

Early Sugar .............\$ 10

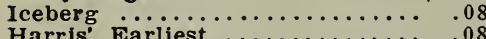

Harris Earliest $\ldots \ldots \ldots \ldots \ldots \ldots \ldots, .08$

Black Diamond $\ldots \ldots \ldots \ldots \ldots \ldots \ldots \ldots . .08$

Halbert's Honey ........... .08

Rattlesnake ................ .08

Light Icing ..............

Peerless or Ice Cream........ .08

Mountain Sweet $\ldots \ldots \ldots \ldots \ldots \ldots . .08$

Kentucky wonder $\ldots \ldots \ldots \ldots \ldots \ldots . .0 \%$

Mer's Sweet

Triumph $\ldots \ldots \ldots \ldots \ldots \ldots \ldots \ldots \ldots . .08$

King of Mammoth .......... 08

Kleckley's Sweet ............ .08

Kolb's Gem .............. .08

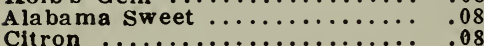

Citron $\ldots \ldots \ldots \ldots \ldots \ldots \ldots \ldots \ldots, \quad .08$

OKRA.

White velvet $\ldots \ldots \ldots \ldots \ldots \ldots \ldots \$ .08$

ONION SEED.

Yellow Globe Danvers ........\$ .10

Zimmerman's Earliest Red .... 10

Early Red Globe ............ 10

Australian Brown .............. 10

White lortugal or silver Skin...

Southport Red Globe ......... .10

Southport White Globe ....... .15

Large Red Wethersfield ....... . 10

Anierican Prize-Taker .......... 10

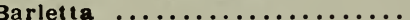

Manımoth silver King ........ 10

White Bermuda ............ .15

Red Bermuda $\ldots \ldots \ldots \ldots \ldots$
Southport Yellow Globe $\ldots \ldots \ldots$

PUMPKIN.

Thanksgiving Pie $\ldots \ldots \ldots \ldots \ldots \ldots .08$

Small Sugar

Japanese Pie $\ldots \ldots \ldots \ldots \ldots \ldots \ldots \ldots, .08$

Cashaw

King of Mammoth .......... .10

Common Field ............. .05

Kentucky Fleld ........... .05

Cheese Pumpkin $\ldots \ldots \ldots \ldots \ldots \ldots . .05$

PARSNIP.

Hollow Crown Sugar $\ldots \ldots \ldots \ldots, .05$

Guernsey $\quad \ldots \ldots \ldots \ldots \ldots \ldots \ldots$
ONION sETs.

Yellow Bottom $\ldots \ldots \ldots \ldots \ldots \ldots \$$.10

Red Bottom ...............

White Bottom $\ldots \ldots \ldots \ldots \ldots \ldots \ldots, \quad .12$

PEAS.

Two Weeks Early ..........\$ .30

First and Best ............ .30

American Wonder .............. $\quad .35$

Alaska .....................

Little Gem $\ldots \ldots \ldots \ldots \ldots \ldots \ldots \ldots \ldots, \quad .30$

Gradus or Prosperity .........

Improved Stratagem ........ . .30

Nott's Excelsior ............ .35

Zimmerman's Reliance ......... .30

Bliss' Everbea ring ............. .30

Champlon of England $\ldots \ldots \ldots \ldots, \quad .30$

Telephone ................ .30

Whlte Marrowfat ........... .25

Early Winner $. . \ldots \ldots \ldots \ldots \ldots \ldots . .40$

PARSLEY

\$ L L $10 . \mathrm{Lb}$.

.25

.25

25
.25

25
.20

. 25

25

.30
.25

.25
.25

.25

25

.30
.30

$\$ .35$

.15

.20

.15

.15

.15

.15

.15

.15

.15

.15

.28

.16

.15

.15
.20

.18

$\$ .15$

$\$ .25$

.30

.30
.25

.25
.40

.25

.35

.30
.30

.30
.40

.30

.50

.50
.25

$\$ .18$

.15

.18

.18

.15

.15

.15

.12

.12

Pk.

.70
.75

.75
.80

$\$ 2.10$

2.00
2.75

2.10

2.25
2.75

2.00

2.00
2.50

2.50
2.25

2. 25

2.00

1.25

1.25
3.00

Bu.

7.50

9.51 \begin{tabular}{r|r} 
Eb. & \\
1.40 & $\mathrm{C}$ \\
.80 & $\mathrm{~N}$ \\
.75 & \\
.75 & \\
.75 & \\
.60 & \\
.75 & $\mathrm{R}$ \\
.75 & 1 \\
1.00 & $\mathrm{C}$ \\
.75 & \\
.75 & $\mathrm{~S}$ \\
.75 & $\mathrm{~L}$ \\
.75 & $\mathrm{C}$ \\
.90 & \\
.90 &
\end{tabular}

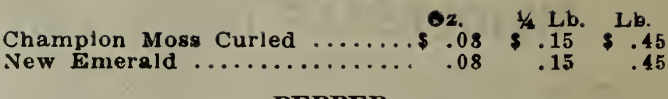

PEPPER.

New Mammoth ............. $.20 \$ .60 \$ 2.20$

Ruby King ............... .15 $\$ .50 \$ \ldots .90$

l'rocoop's Giant $\ldots \ldots \ldots \ldots \ldots \ldots \ldots . .15 \quad .50 \quad 1.90$

Chili ........................ $15 \quad .50 \quad 1.75$

$\begin{array}{lllll}\text { Lolden Dawn Mango ......... } & .15 & .50 & 1.75 \\ \text { Sweet Spanish or Large Bell... } & .15 & .50 & 1.75\end{array}$

Long Red Cayenne ............ $.15 \quad .50 \quad 1.75$

RADISH.

Early Scarlet Crlsp .........\$ .10 \$.35 \$1.00

$\$ .90$ Early Scarlet Globe $\ldots \ldots \ldots \ldots \ldots .05$

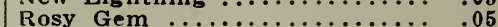

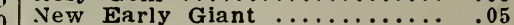

Early Turnip Red ............ .05

60 Early Turnip White Tipped .... .05

(1) Early Turnip White ........ .05

Chartiers $\ldots \ldots \ldots \ldots \ldots \ldots \ldots .05$

New Leafless $\ldots \ldots \ldots \ldots . .05$

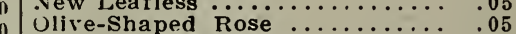

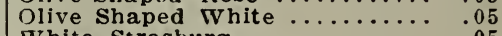

White Strasburg .............. 05

New white Chinese ...................

Rose China Winter ............. 05

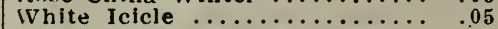

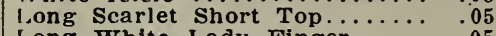

.50

.60

(

\section{RHUBARB.}

SPINACH.

New Long Standing ........... $55 \$ .08 \$ .15$

Round Thlck Leaved ...........05 .08 .08

Prickly Wlnter................ .05, .08 .15

1.00 Bloomdale or Savoy Leaved.... $.05, .08$.15

1.50

90

1.25

1.10

1. 30

1.10

1.90

$\begin{array}{r}.90 \\ \hline\end{array}$

$\$ .60$

.51

.611

.711

.35

.40

.35

$\$ 2.5$ n

2.75
3.00

$\$ 8.00$

7.511

10.011

8.10
8.50

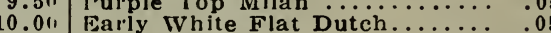

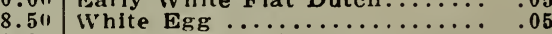

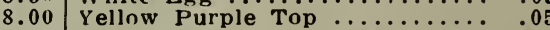

4.75 Red Top Globe Rutabaga........ 05

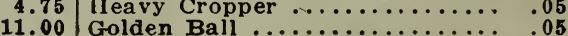

$\$ 1.00 \$ 3.50$

$.50 \quad 1.75$

$.50 \quad 1.75$

$.50 \quad 1.75$

$.75 \quad 2.25$

$.50 \quad 1.75$

$\begin{array}{ll}.50 & 1.75 \\ .50 & 1.75\end{array}$

$.50 \quad 1.75$

$.50 \quad 1.75$

$.75 \quad 2.25$

$.75 \quad 2.25$

$.50 \quad 1.75$

$.50 \quad 1.75$

$.50 \quad 1.75$

$\begin{array}{ll}.50 & 2.00 \\ .50 & 1.75\end{array}$

TURNIP.

Purple Top Strap Leaved......\$.05

$\$ .15 \$ .40$

$.15 \quad .50$

.15 .50

$\begin{array}{ll}.15 & .40 \\ .15 & .40\end{array}$

$.15 \quad .35$

$.15 \quad .35$

$.15 \quad .40$
$.15 \quad 2.50$ 

ORDER SHEET
ZIMMERMAN
SEED CO., Topeka,
Kansas
Date,
1912
Name
Write your name plain and distinct)
AMOUNT ENCLOSED
Post Office
County
R. F. D.
State
Send This Order by State whether by Mail, Express or Freight
Express Office
Post Office Order $\$$
Express Order
$\$$
Cash $\quad-\quad \$$
Draft - $\quad \$$
Stamps $\quad-\$ \ldots+\ldots .$.
Freight Office
When ordered by express or treight, give express or freight offlce

POSTPAID BY MAIL. We pay the postage on packets, ounces, $1 / 4$ pounds, $1 / 2$ pounds, pounds, pints and quarts. All you have to do is to make out a list of the seeds wanted, attach the price to each and send the amount by money order, draft or registered letter.

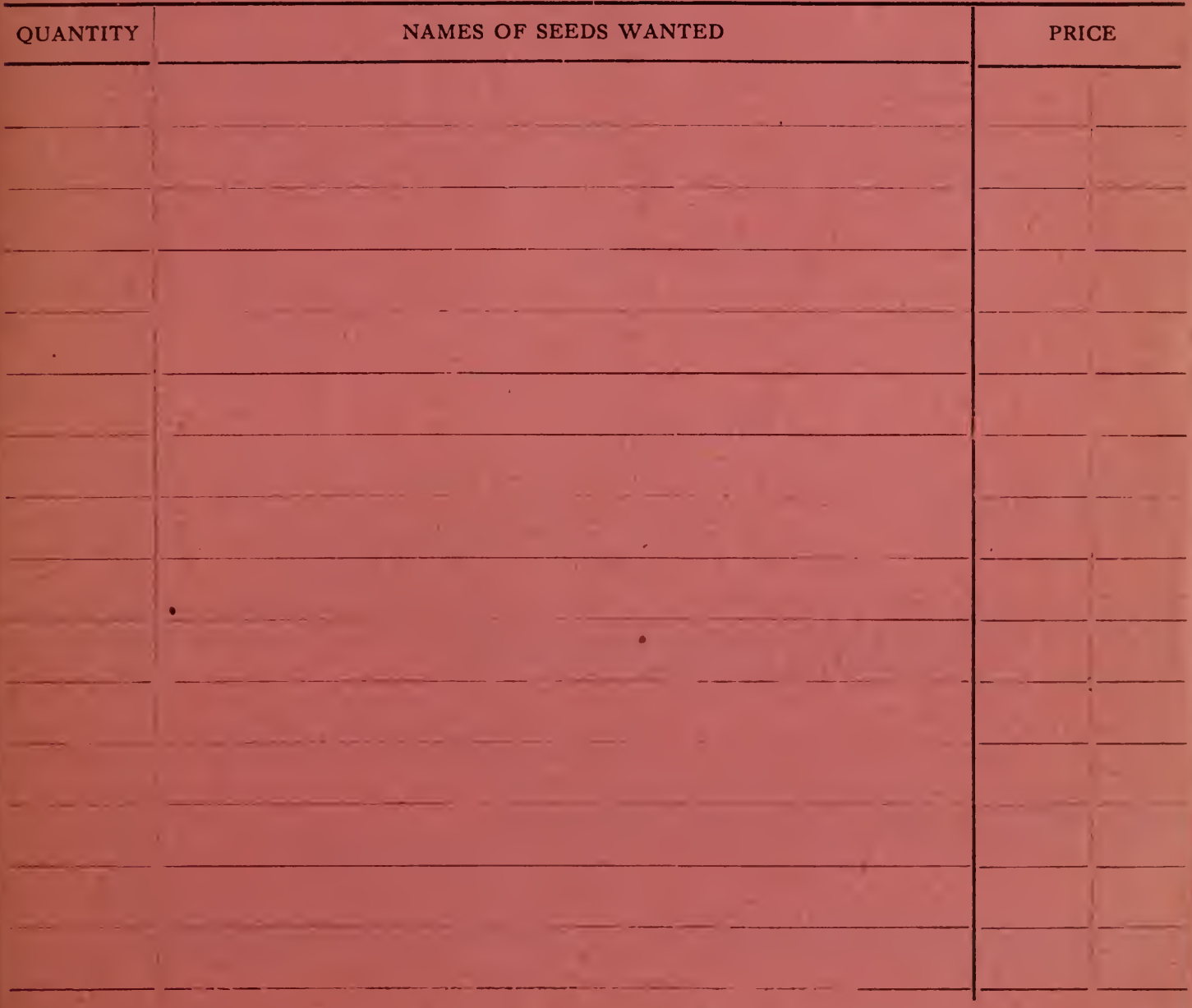




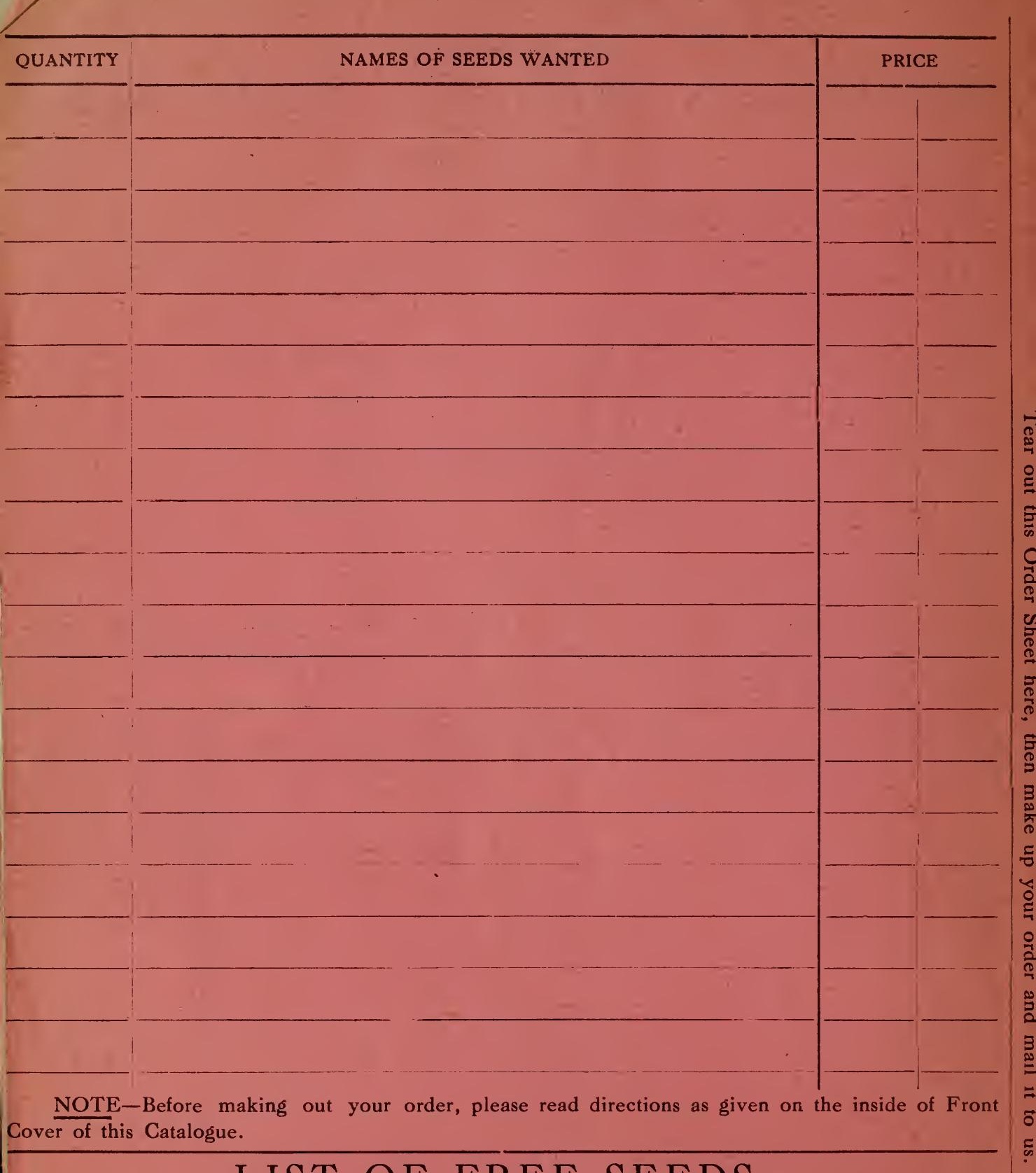

\section{LIST OF FREE SEEDS:}

For every ONE DOLLAR'S worth of seeds ordered in PACKETS and OUNCES, you may select TWENTY-FIVE CENTS worth in Packets and Ounces FREE. Write your FREE selections in space below. Collections cannot be given Free. 


\section{Field Seeds-Continued}

Soy Beans-Early Yellow-The earliest and best variety. One peund, 20 cents, postpaid. By express or freight, one-half bushel $\$ 1.70$; bushel $\$ 3.25$.

Castor beans-Uestroys moles, etc. One pound, 15 cents, postpaid. By express or freight, 10 cents per pound.

Cow Peas-Either the New Era, Whippoorwill or Black-Eyed. $\$ 3.50$ per bushel.

Tobacco-Either Connecticut Seed Leaf or Big Havanna. Packet, 5 cents; one-half ounce, 16 cents; ounce, 20 cents; one-quarter pound, 75 cents; pound, $\$ 2.80$, post paid.

Bıomus lnezmis-1 his is becoming very popular; grows from 3 to 5 feet high, and is a drouth resister. It will succeed in a wider ralige of temperature than any other grass will on poor land, and will become permanent pastuse. Sown 20 to 30 pounds per acre. Pound, 30 cents, postpaid. By express or freight, 100 pounds, $\$ 10.00$.

Red '1op-Succeeds besi in moist land. Pound, 30 cents, postpaid. By express or freight, peck, 80 cents; bushel, $\$ 3.10$.

Milo Maiz_-Resembles Kaffir, but preferred by many to Kaffir. Pound, 16 cents, postpaid. By express or freight, $\$ 2.50$ per hundred.

English Blue Grass-(Meadow Fescue)-Pound, 15 cents, postpaid. By express or freight, bushel, 22 pounds, $\$ 7.50$.

Orchard Grass-Does well in the shade. $\$ 2.75$ per bushel.

German Millet-\$2.50 per hundred.

Siberian Millet- $\$ 3.00$ per hundred.

Japanese Millet or "Billion Dollar Grass"-Packet, 5 cents; pound, 30 cents, post paid. By express or freight, $\$ 4.00$ per hundred.

speltz or Emmer-Will grow anywhere and makes a good pasture when in the green stage. One pound, 15 cents, postpaid. By express or freight, 90 cents per bushel.

Quick Growing Lawn Grass-My special mixture will insure a beautiful, compact, even sod. It includes the finest door or yard grasses, with a select proportion of Kentucky Blue Grass, etc. Our Lawn Grass is liot "dished out of any old seed," but is carefully selected. It is not the cheapest but is the best lawn mixture offered. Pound, 30 cents; 3 pounds, 75 cents, postpaid. By express or freight, 5 pounds, $\$ 1.25 ; 50$ pounds, $\$ 12.50$.

Sweet Clover or Bokarah-This produces abundance of small white flowers which are fine for bees. It is rapidly coming into use throughout this section. It is good for pastures. 30 cents per pound, postpaid. By express or freight, 50 pounds, $\$ 10.00$; 100 pounds, $\$ 19.00$.

Pearl Millet-Has recently b en called Peicillaria and sold at high prices, but is the old Pearl or Cat Tail Millet. In drills sow 3 to 4 pounds per acre; broadcast, 8 pounds per acre. Pound, 20 cents, postpaid. By express or freight, 10 pounds, $\$ 1.20 ; 50$ pounds, $\$ 6.00$.

Teosinte-Relished by sheep, logs and cattle. Plant in drills 3 feet apart, 2 or 3 seeds every foot, 4 pounds per acre. Ounce, 8 cents, one-quarter pound, 25 cents; pound, 80 cents; 3 pounds, $\$ 2.25$, postpaid.

Flax-Sow about 40 pounds pe* acre. Packet 5 cents; pound, 20 cents; 3 pounds, 55 cents, postpaid. By express or freight, peck, 90 cents; bushel, $\$ 3.00$.

Barley-Champion Beardless--By express or freight, peck, 50 cents; bushel, \$1.75. Sixrowed Barley, peck, 40 cents; bushel, $\$ 1.50$.

Japanese Buckwheat-It is the hardiest and most productive Buckwheat grown. Pound, 16 cents, postpaid. By express or freight, pack, 40 cents; bushel, $\$ 1.50$.

Jerusalem Corn-Pound, 20 cents, postpaid. By express or freight, 50 pounds, $\$ 2.75 ; 100$ pounds, $\$ 5.00$.

Broom Corn-(Oklahoma Dwarf)-Is early, of dwarf habit, resists drouth, and is very productive, making a fine paying crop for new settlers. Drill 3 pounds of seed per acre. Pound, 15 cents, postpaid. By express or freight, peck, 55 cents; one-half bushel, $\$ 1.20$; bushel, $\$ 2.25$.

Improved Evergreen-Pound, 15 cents, postpaid. By express or freight, peck, 55 cents; bushel, $\$ 2.25$.

NOTICE for Seed Corn see Catalogue.

\section{Sweet Potatoes}

We exercise the greatest rare in parking Sweet Potatnes, but, owing to their extreme tenderness, cannot guarantee safe arrival, esnecially on long distances. The plants are shipped onlv bv express. We have good storks of Yellow .Tersey. Yellow Nansemond. Red Jersey, Red Nansomond. Red Bermuda. Snithern Oroen and Yams. Perk, 40 cents; bushel, \$1.25.

Sweet Potato Plants-Yellow, Red and Southern Oween. 50 for 30 cents; 100 for 50 cents, by mail postpaid. By express, 500 for 80 cents; 1,000 for $\$ 1,50$.

NOTICE-For Seed Corn see Catalogue. 


\section{Seed Oats}

Oats are very scarce this year, and a great deal of last season's crop has been carried over. We guarantce our seed to be new 1911 crop. We do not run a feed store, onsequently we buy oats only for seed. It is carefully screened and graded.

Rcd Texas-More generally planted in Kansas and the Southrest than any other oat. I have a nice stock cirect from Texas. By express or freight, busiel, 90 cents.

Kherson-One of the earliest varieties and a heavy yielder. By express or freight, bushel, 75 cents.

Early Russian-A very popular hardy and excellent seed oat. By express or freight, bushel, 75 cents.

Zimmerman's Early Winner Oat-The earliest and hardiest oat grown and a decided im. provement over the old 60-day oats. As a seed oat it cannot be surpassed, having a very thin shell which makes it practically all meat. Plant my Early Winner for an early oat crop this season. It will nay you. By express or freight, bushel, $\$ 1.00$.

\section{Potatces}

Seed Potatoes-I griarantee my seed Potatoes to be strictly Red River grown and selected for seed. My pure seed Potatoes are not to be confused with the cheap table Potatoes sometimes offered by commission houses for seed at a low price. In planting potatoes get pure seed:

Early Delight-A cross between the Early Ohio and Six Weeks; coubinirg the heavy yielding qualities of the Ohio with earliness of the Six Weeks, thereby makirg it an ideal potato. It is of handsome form and light color; comes true and not easy to "scab." Peck, 40 cents; one-half bushel, 75 cents; bushel, $\$ 1.40 ; 3$ or more bushels, $\$ 1.50$ per bushel.

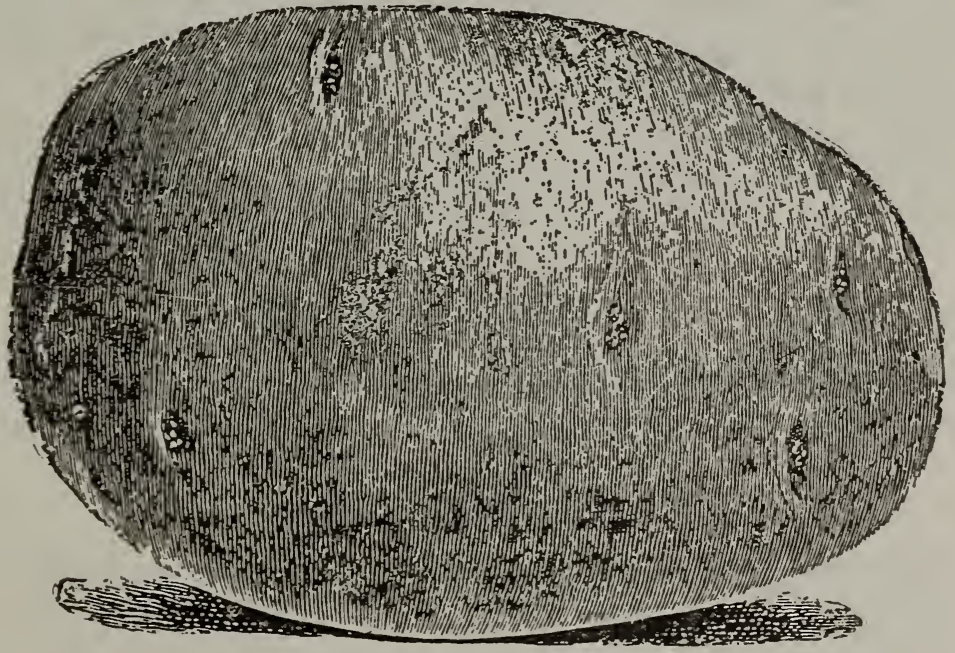

Zimmerman's Early Delight.

Early Orio-The most popular potato in the West. I guarantee my stock standard; to be strictly Red River grown, which is the finest quality. Don't buy chenp seed potatoes. Peck, 40 cents; one-half bushel, 70 cents; bushel, $\$ 1.30 ; 3$ or more bushels at $\$ 1.25$ per bushel.

Early Triumph-Combines productiveness, earliness, with heavy yielding qualities; color is a light red and they grow to a large size. Peck, 45 cents; one-half bushel, 80 cents; 3 or more bushels at $\$ 1 . \dot{5} 0$ per bushel.

Early Rose-This is the old staniard early potato. Extra large size, and a good producer. Peck, 40 cents; one-half bushel, 70 cents; bushel, $\$ 1.30 ; 3$ or more bushels at $\$ 1.2$. per bushel.

Six Weeks-The earliest potato in existence and has been a leading garden potato. Peck. 40 cents; one-half bushel. 70 rents; bushel, $\$ 1.30 ; 3$ or more bushels at $\$ 1.25$ per bushel.

Burbank-The standard late notato; large. heavv vielding and the favorite main crop po. tato. Peck, 40 cents; one-half bushel, 70 cents; busbel, $\$ 1.30$ per bushel; 3 or more bushels at \$1.25 per bushel. 

No seedman I know of makes such liberal offers, or supplies the same high grade seed at as low prices. By simply publishing a plain, neat catalogue, which tells the plain truth, I make a large saving in expense. I also deal directly with the growers, thus eliminating the middleman's profits. It will pay you to send me your order. Try it this year.

\section{Complete Flower Garden for 25 Cents}

I offer the following 15 packets for only 25c, postpaid. A regular 75 c collection. All are easily grown from seed and you will find this will make a gorgeous flower bed:

Aster, Fine Mixed. Ayssum, Little Gem, heautiful pure white. Carnations, New Marguerite, grand mixture. Candytuft, Fine Mixed. Cosmos, Fancy Mixed. Larkspur, Finest Mixed. Mignonette, All the Best Mixed. Nasturtium, Grand Mixture. Portulaca, Choice, All Colors. Pansy, Grand Mixture of Giant Varieties. Fetunia, Fancy Colors, Grand Display. Phlox, Finest Mixed, Elegant Assortment. Poppy, All Sorts and Colors. Sweet Peas, Our Select Mixture of the Finest and Best. Verbenas, Fine Collection of Mixed Colors.

\section{Grandmother's Flowers}

When we get down to the facts, there is nothing more beautiful than the old-fashioned flowers, such as our grandmothers raised. With this thought in mind I have prepared a special collection composed entirely of old-fashioned flowers, which for beauty and attractiveness cannot be excelled. One packet each of the following varieties sent postpaid for only 25c:

Bachelor's Eutton-Always a favorite. Coxcomb-The choicest old-fashioned feathered varieties. Cypress-The finest of any garden rines. Four 0'Clock-Too well known to need any description. Forget-Me-Nots-Largest flowering varieties. Larkspur-Well liked for its rich colors. Marigold-All rarieties mixed. Hollyhock-Singles and doubles mixed. Morning Glory-The genuine Japanese varieties. Petunias-Finest mixed. Poppy-Finest mixed. Rose Moss-Finest varieties and free blcomers. Sunflowers-Double and many flowering. Snapdragon-Always will be a great farorite. Touch-Me-Not-Just the old-fashioned varieties. Zinnias-Best varieties mixed.

\section{Surprise Flower Garden}

This mixture is made up of over 75 varieties of easy culture. . Some very rare flowers will be found in this collection. A great deal of pleasure may be derived from this collection. Get it for the children, that they may learn the different flowers. Large pkt. of over 75 rarieties for only j̃e.

\section{ZIMMERMAN SELD CO. Topeka, Iransas}




\section{ZIMMERMAN'S \\ Complete Garden Collections}

We have prepared the following collections very carefully and believe they cover the requirements of the average private garden. They are from our regular High Grade Stock, FRESH AND PURE, and you will find them great money savers, as we have fixed the price very low. READ THEM CAREFULLY.

\section{One Dollar Packet Collection}

We send you 39 full size packets, postage paid for only $\$ 1.00$

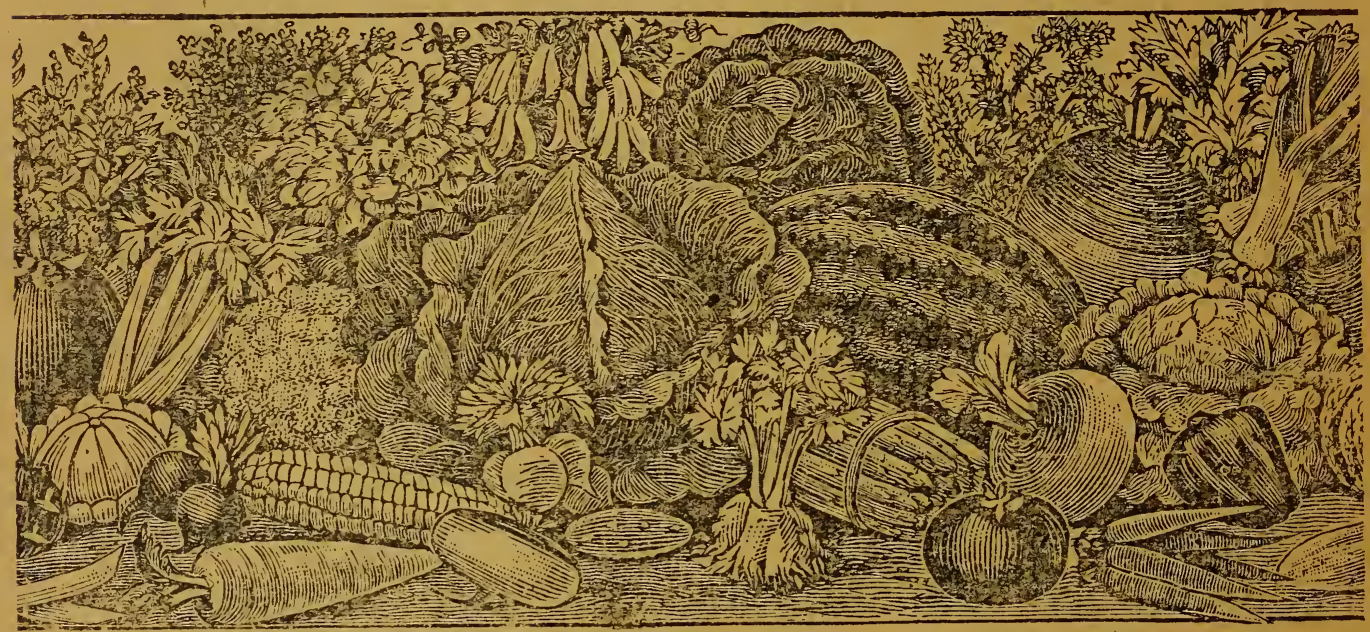

Asparags-Palmetto. Bus Lima. Red Valentine. Bush LeetEgyptian. I.entz. Cablage-Extra Early. Late Variety. Carrot-Danver's Half Long. Celery-White Plume. Sweet Corn-Evergreen. Curumber-Zimmerman's Earliest. Watermelon-7immerinan's Earliest. Improved Hanson. Musk Melon-Montreal Market. Danvers. Peas Kolb's Gem. Kentucky Wonder. Onion-Large Rer Wethersfield. Yellow Globe Danvers. Peas -Nott's Excelsior. Yorkshire flero. Pie. Parsnip- Hollow Crown Lightning. Long Scarlet Short Top. Spinach-New Iong Stanfling. Salsify-Mammoth Sandwich Island. Squash-Hubbard. mato-Paragon. Gold Dust (Red). Turnip-Early Flat Dutch. Yellow Purple Top. In addition, you may solect 25e worth, in packets, FREE. All postpaid for \$1.00.

\section{$\$ 1.00 \mathrm{Boz}$ Home Garden $\$ 1.00 \mathrm{Box}$}

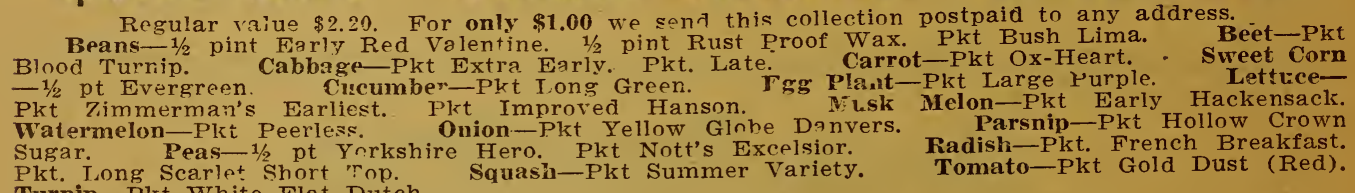
Pkt. Long scarlet Short inp.

In a making the value of this collection $\$ 2.20$, which we are offering for ONLY $\$ 1.00$ postpaid.

\section{$\$ 2.00$ Box Family Garden $\$ 2.00 \mathrm{Box}$}

This collection has provon very popular and will supply the average family with choice vegetables
ONL $\$ 2.00$. Our seeds have a rate of 20 per

cent less than regular merchandise, making the crst light. Turnip. Cabbage-Pirt Es rly. Pkt T,ate. Calentine. 1/2 pint Bush Larrot-Pkt Half Long Danvers. $1 / 2$ pint Earlv. Pint Stowell's Evergroon. Cucumber-Pkt Zimmerman's Earliest. Pkt Long

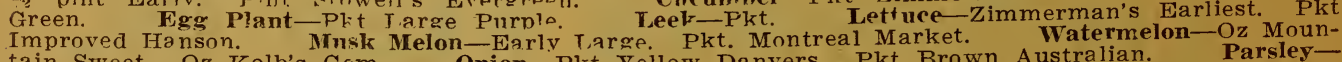
tain Sweet. Oz Kolb's fam. Onion-Plyt Yellnw Danvers. Pkt Brown Australian. Pkt. Parsnip-Pkt Hollow Crown Sugar. Peas-Pint Nott's Excelsior. Pint Everbearing. Oz New Iightning. Pepper-Pkt Ruby King. Pkt. Cayenne. White Inicle. Pkt. Long Scarlet Short Top. Salsify-Pkt. Pkt. Squash-Pkt Summer Pkt Hubbard. Tomato-Pkt Early Wonder. Pkt. Western Giant. Turnip-Plit White. Milian.

In addition, you may select 50e worth in packets FREE, malking this a grand collection. 


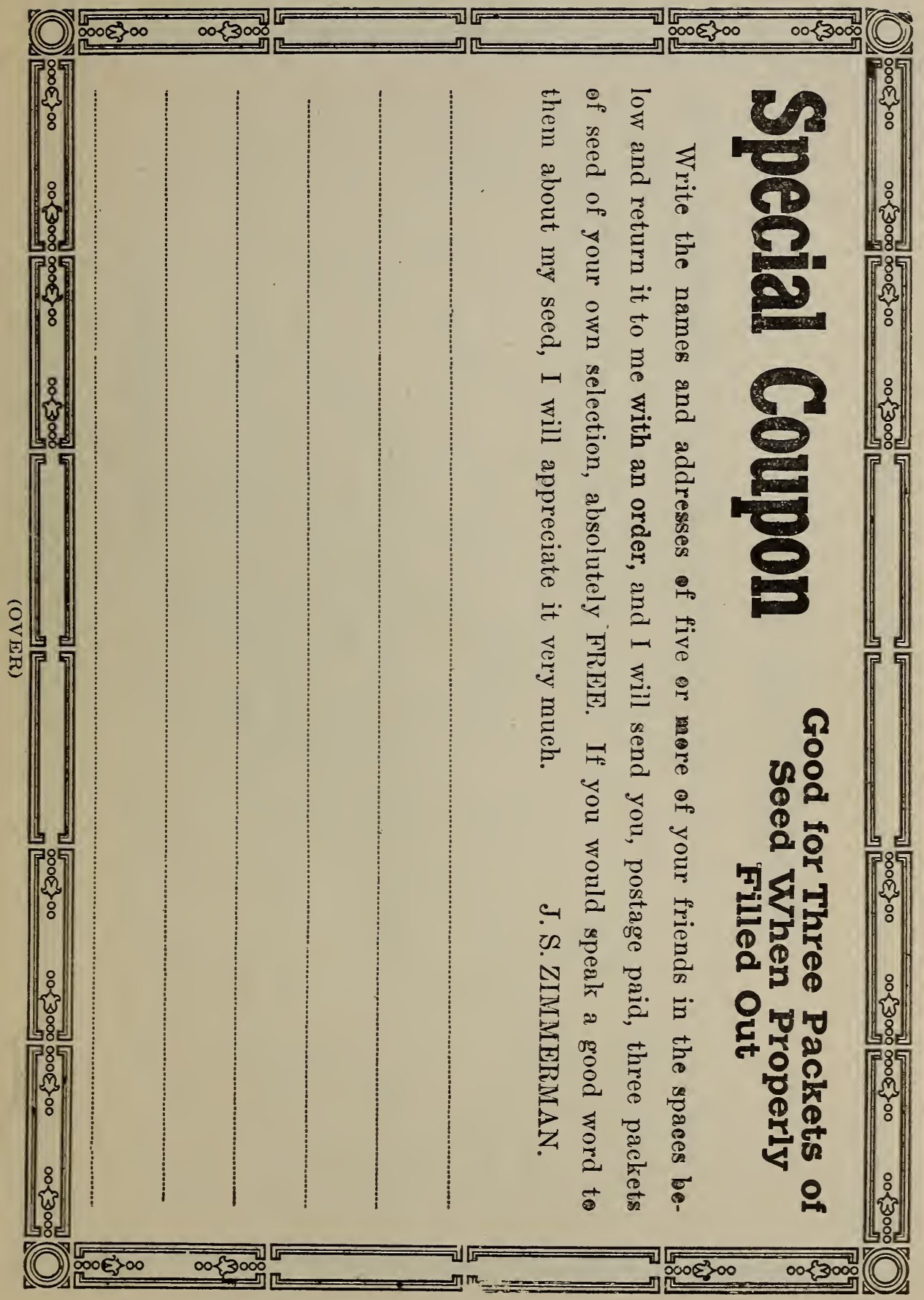



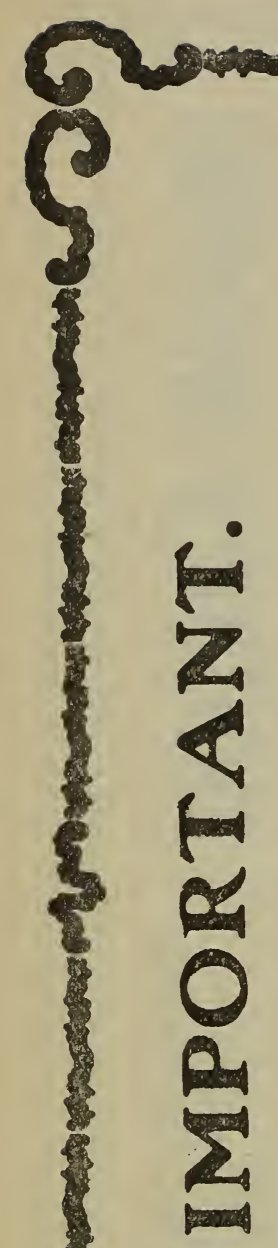

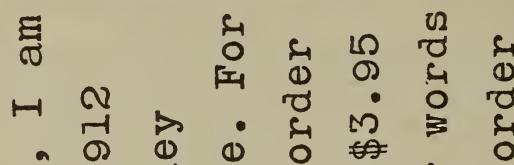

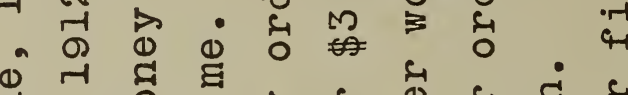

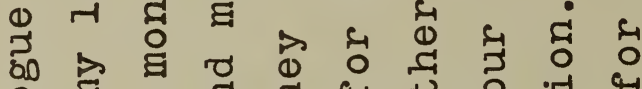

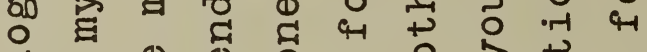

त)

+0 ० 0 व 10 (1) ब

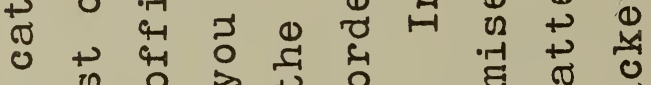

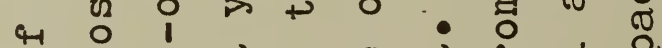

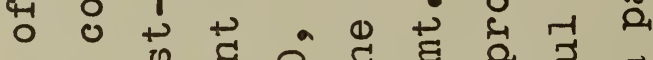

(1)

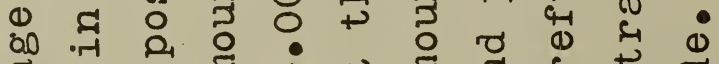

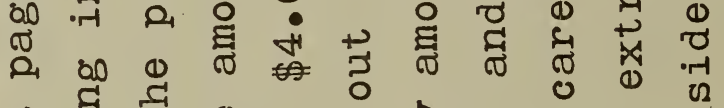

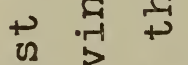

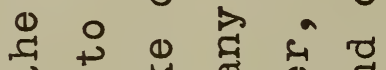

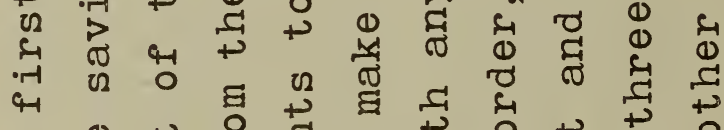

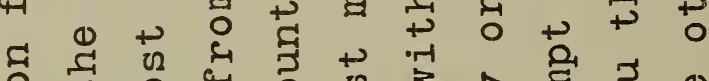

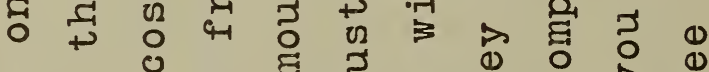

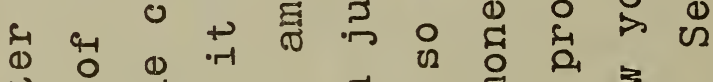

告

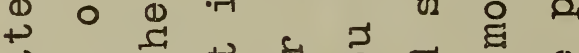

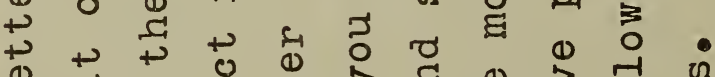

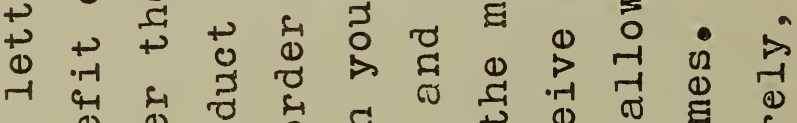

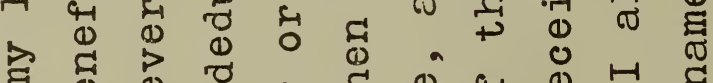

(4)

Q 10 \&

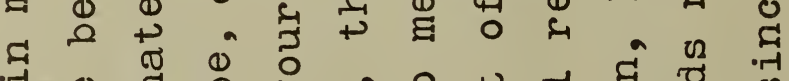

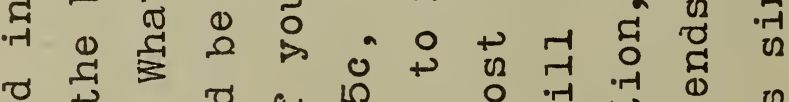

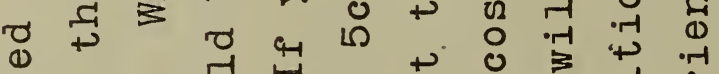

$+2 \cdot$ J

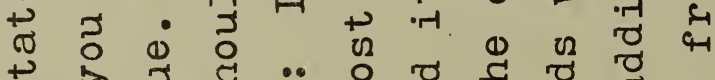

ข $\gg$ वे

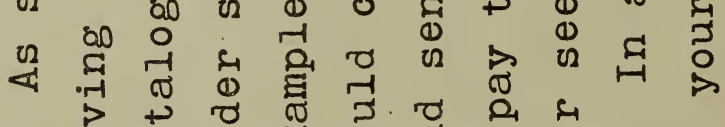

$\rightarrow+\infty$ व

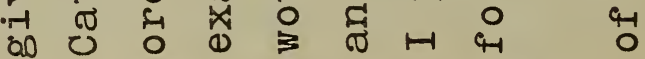


VEGETABLES.

Artichoke ........ 3

Anise ...........

Asparagus ........ 3

Beans .......... 4

Beets ............ j

Borecole or Kale....19

Broccoli ..........19

Brussels Sprouts....19

Borage ............

Cabbage ..........

Carrot ......... 7

Cauliflower $\ldots \ldots \ldots 7$

Caraway ..........19

Catnip ............

Celeriac .......... 7

Celery .........

Chicory $\ldots \ldots \ldots \ldots 19$

Collards ..........19

Coriander ............
Corn, Pop......... 8

Corn, Sweet........ s

Cress ...............

Cucumber ........ 9

Dill ..............

Egg Plant..........

Endive .......... 13

Garlic ............. 19

Horehound .........19

Hop Seed........... 19

Kohi-Rabi ........6 6

Lavender ...........19

Leek .......... 19

Lettuce ...........10

Melons, Musk.......11

Melons, Water......12

Mushroom Spawn...13

Mustard ...........19

Okra or Gumbo.....13

Onion ...........13
Parsley ..........15

Parsnip ............15

Peanuts ...........13

Peas .............14

Pepper ............ 15

Pepper Grass.......19

Pumpkin ....................

Potatoes .........22

Radish ...........16

Rhubaro ...............

Rutabaga ..........

Salsify ...........

Saffron ........... 19

Sage .............. 19

'Savory ........... 19

Spinach ............

Squash ................

Thyme ...............

Tomato ............17

Turnip ...........18
FLOWER SEED.

Pages..23, 24, 25, 26, 27 Bulbs ..........29

\section{MISCELLANEOUS.}

Page ............19

FIELD SEEDS.

Pages .....20, 21, 22

ROSES AND PLANTS.

Pages ........30, 31

POCLTRX AND BEE SUPPLIES.

Page .............32

\section{Seeds and Roots Required}

Artichoke, oz. of seed to 500 plants.

Asparagus, oz. of seed for 500 plants.

Beans, dwarf, $1 \frac{1 / 2}{p t}$. to 100 feet of drill; $1 \frac{1 / 4}{b u}$. per acre.

Beans, pole, one qt. to 100 hills.

Beet, one oz. to 100 feet of drill; 5 to $6 \mathrm{lbs}$. per acre. Brussels Sprouts, one oz. to 5,000 plants.

Cabbage, one oz, to 3,000 plants.

Carrot, $1 / 2$ oz. to 100 feet of arill; 2 to 3 lbs. per acre.

Cauliflower, one oz. to 3,000 plants.

Celery, 1 oz. to 10,000 plants.

Corn, one qt. to 200 hills; 8 to $10 \mathrm{lbs}$. per acre.

Cucumbers, one oz. to 100 hills.

Egg Plants, one oz, to 2,000 plants.

Endive, $1 / 4$ oz. to 100 feet of drill.

Kale, one oz. to 5,000 plants.

Lettuce, $1 / 4 \mathrm{oz}$. to 100 feet of drill.

Melon, Musk, one oz. to 100 hills; 2 to 3 lbs. per acre.

Melon, Water, one oz. to 50 hills; 3 to 5 lbs. per acre.

Okra, one oz. to 75 feet of drill.

Onion seed, one oz. to 200 feet or drill; 5 lbs. per acre.

Onlon seed, for sets, 40 to 50 lbs. per acre.

Onion sets, one qt. to 38 feet of drill; 6 bu. per acre.

Parsnip, $1 / 2$ oz. to 100 feet of drill; 3 to $5 \mathrm{lbs}$. per acre.

Parsley, $1 / 2$ oz. to 100 feet of drill.

Peas, garden, one qt. to 100 feet of drill; $1 \frac{11 / 2}{b u}$. per acre.

Peas, cow, $1 \frac{1 / 2}{b u}$. per acre.

Pepper, one oz. to 1,500 plants.

Pumpkin, one oz. to 75 hills; 5 lbs. per acre.

Radish, one oz. to 100 feet of drill; 6 to 8 lbs. per acre.

Salsify, one oz. to 75 feet of drill; 6 to 8 lbs per acre.

Spinach, one oz. to 100 feet of drill; 10 lbs. per acre. Squash, one oz. to 75 hills; 5 lbs. per acre.

Tomato, one oz. to 2,500 plants.

Turnip, one oz. to 200 feet of drill; $1 \frac{11 / 2}{1 b s}$. per acre.

\section{Table of Field Seeds}

\section{Pounds Pounds}

per Busheì per Acre

Alfalfa Seed ..............60... to 25

Alsike Clover ...........60... \& to 10

Kentucky Blue Grass, for lawns..14...40 to 50

Kentucky Blue Grass, pasture...14...10 to 15

Red Clover .............60...10 to 12

White Clover .............60.... 3 to 5

Timothy seed $\ldots \ldots \ldots \ldots \ldots \ldots$ to 12

English Blue Grass .........22...20 to 30

Orchard Grass ..............12 to 15

Red Top ..................... to 12

Red Top Chaff .................. to 40

Bromus Inermis .............20 to 30

Millet .................... 40 to 40

Cane Seed, Broadcast .......50...50 to 100

Cane Seed, in Drills .............. \& 8 to 12

Broom Corn ................... to 48 qts.

Corn, Field ............

Corn, Sweet .................. $50 \ldots$ to 5 qts.

Corn, Pop ...................

Kaffir Corn, in drills........... 8 to 12

Kaffir Corn, broadcost ......56...30 to 50

Speltz ...............40...40

Essex Rape .................. 4 to $s$

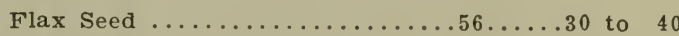

Buckwheat $\ldots \ldots \ldots \ldots \ldots \ldots \ldots 50 \ldots \ldots 25$ to 50

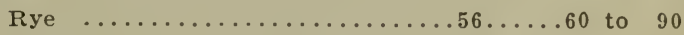

Hemp ....................... to 50

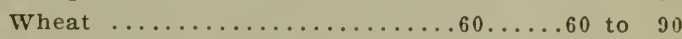

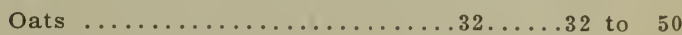

Barley .....................60 to 95

Soja or Soy Beans, drills......60...20 to 30

Soja or Soy Beans, broadcast...660...660

Cow Peas .....................60 to 120 


\section{ZIMMERMAN SEED CO. TOPEKA, KANSAS}

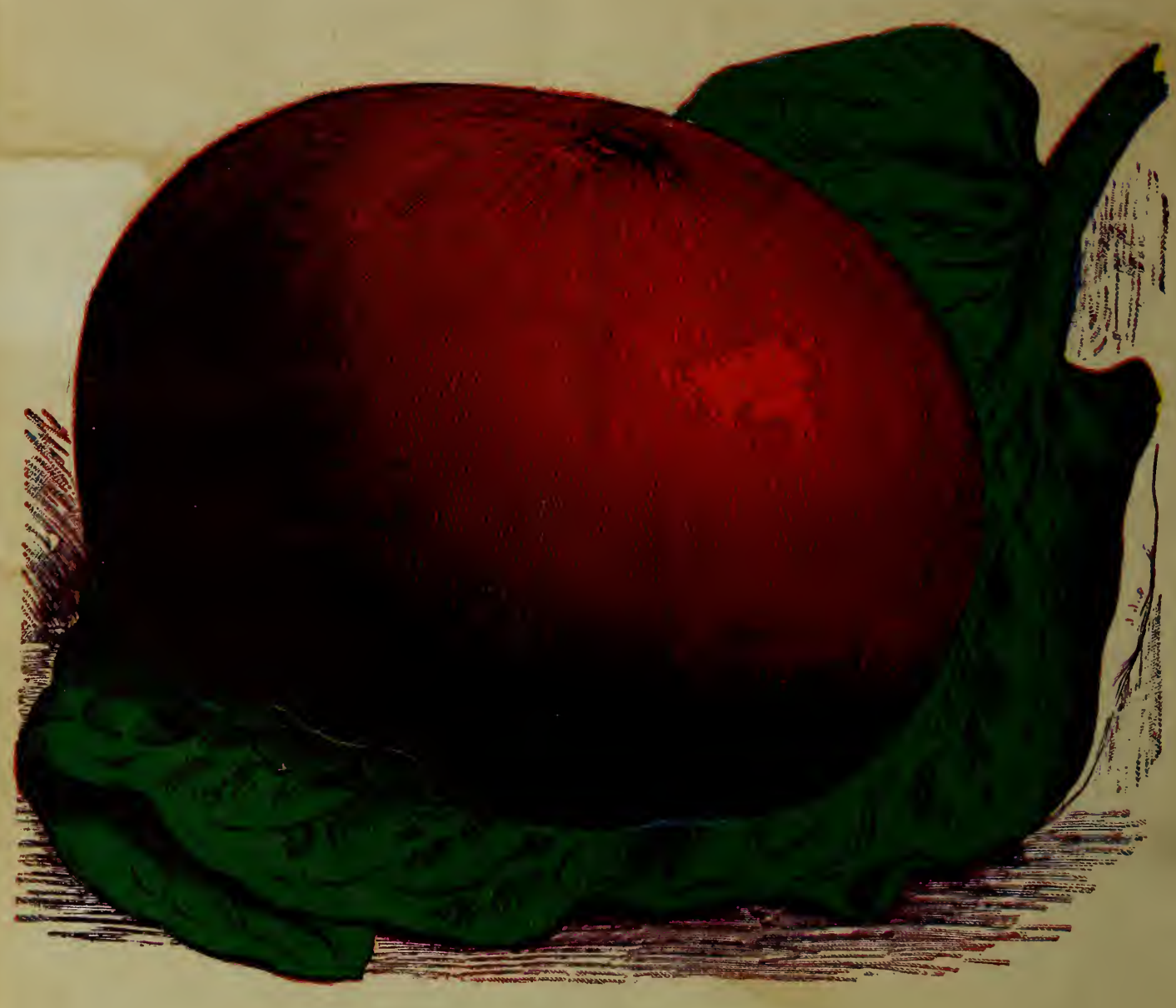

THE CRIMSON BALL TOMATO

Packet 10 Cents. See Page 17

$\underline{1912}$ 